\title{
Neutral Benzoquinolate Cyclometalated Platinum(II) Complexes as Precursors in the Preparation of Luminescent Pt-Ag Complexes
}

\author{
Miguel Baya, ${ }^{[a]}$ Úrsula Belío, ${ }^{[a]}$ Juan Forniés, ${ }^{[a]}$ Antonio Martín, ${ }^{*[a]}$ Mariano \\ Perálvarez $^{[b]}$ and Violeta Sicilia ${ }^{[c]}$ \\ [a] Instituto de Síntesis Química y Catálisis Homogénea (ISQCH), CSIC - \\ Universidad de Zaragoza, Departamento de Química Inorgánica, Facultad de \\ Ciencias, 50009 Zaragoza, Spain. \\ [b] IREC, Catalonia Institute for Energy Research. Jardins de les Dones de Negre \\ 1. PL2, 08930 Sant Adrià de Besòs, Barcelona, Spain. \\ [c] Instituto de Síntesis Química y Catálisis Homogénea (ISQCH), CSIC - \\ Universidad de Zaragoza, Departamento de Química Inorgánica, Escuela de \\ Ingeniería y Arquitectura de Zaragoza, Campus Río Ebro, Edificio Torres \\ Quevedo, 50018, Zaragoza Spain.
}

e-mail addresses: Prof. Juan Forniés: juan.fornies@unizar.es Dr. Antonio Martín: tello@unizar.es 


\section{Abstract}

Complexes $\left[\mathrm{Pt}\left(\mathrm{C}_{6} \mathrm{~F}_{5}\right)(\mathrm{bzq})(\mathrm{CNR})\right]\left\{\mathrm{R}={ }^{t} \mathrm{Bu}\right.$ (1), 2-naphthyl (2), 2,6-Me $\mathrm{Me}_{2} \mathrm{Ph}$ (3) $\}$ have been prepared by replacement of the labile acetone in $\left[\mathrm{Pt}\left(\mathrm{C}_{6} \mathrm{~F}_{5}\right)(\mathrm{bzq})\left(\mathrm{Me}_{2} \mathrm{CO}\right)\right]$ with the corresponding isocyanide ligand. The structures $\mathbf{1}$ and $\mathbf{3}$ (X-ray) confirms their square planar geometry, with the bzq ligand coplanar to the metal plane. The reactions of 1-3 toward $\mathrm{AgClO}_{4}$ lead to the trinuclear complexes $\left[\left\{\mathrm{Pt}\left(\mathrm{C}_{6} \mathrm{~F}_{5}\right)(\mathrm{bzq})(\mathrm{CNR})\right\}_{2} \mathrm{Ag}\right] \mathrm{ClO}_{4}\{\mathrm{R}=$ ${ }^{t} \mathrm{Bu}$ (4), 2-naphthyl (5) $\}$ or the tetranuclear $\left[\left\{\mathrm{Pt}\left(\mathrm{C}_{6} \mathrm{~F}_{5}\right)(\mathrm{bzq})(\mathrm{CN}-2,6-\right.\right.$ $\left.\left.\left.\mathrm{Me}_{2} \mathrm{Ph}\right) \mathrm{Ag}\right\}_{2}\right]\left(\mathrm{ClO}_{4}\right)_{2}(\mathbf{6})$. The structures of these three polynuclear complexes have been established by X-ray diffraction studies. Two pseudo-polymorphs of 4 (4a and 4b), only differing in the crystallization solvent, have been found. $\mathbf{4 a} / \mathbf{b}$ and $\mathbf{5}$ are trinuclear Pt-Ag-Pt complexes with a "sandwich" disposition. In all three cases, two "Pt $\left(\mathrm{C}_{6} \mathrm{~F}_{5}\right)(\mathrm{bzq})(\mathrm{CNR})$ " fragments are linked by a silver atom through $\mathrm{Pt} \rightarrow \mathrm{Ag}$ bonds of donor acceptor nature and the silver center establishes a short $\eta^{1}$ interaction with the $\mathrm{C}_{i p s o}$ of the bzq ligands. Furthermore, the study of the structure of $\mathbf{6}$ reveals two “ $\left(\mathrm{C}_{6} \mathrm{~F}_{5}\right)(\mathrm{bzq})\left(\mathrm{CN}-2,6-\mathrm{Me}_{2} \mathrm{Ph}\right) \mathrm{PtAg}$ ” subunits, each containing a $\mathrm{Pt} \rightarrow \mathrm{Ag}$ bond related by an inversion center and held together through $\eta^{2}$ interactions established by the silver atom of one unit and one of the aromatic rings of the bzq ligand of the other. The reaction of 1-3 with $\left[\mathrm{Ag}\left(\mathrm{OClO}_{3}\right)\left(\mathrm{PPh}_{3}\right)\right]$ produces $\left[\left(\mathrm{C}_{6} \mathrm{~F}_{5}\right)(\mathrm{bzq})(\mathrm{CNR}) \mathrm{PtAg}\left(\mathrm{PPh}_{3}\right)\right] \mathrm{ClO}_{4}$ $\left\{\mathrm{R}={ }^{t} \mathrm{Bu}\right.$, (7), 2-naphthyl (8), 2,6- $\left.\mathrm{Me}_{2} \mathrm{Ph}(\mathbf{9})\right\}$. These dinuclear clusters contain a $\mathrm{Pt} \rightarrow \mathrm{Ag}$ bond and show dynamic processes in solution (NMR) which involve the rupture and formation of these interactions. The X-ray structure of $\mathbf{7}$ confirms the presence of a Pt-Ag bond and a $\eta^{1}$ interaction with the $C_{i p s o}$ of the bzq ligand (2.514(6) $\AA$ ). All the crystal structures determined show $\pi \cdots \pi$ interactions of the bzq which stack in a parallel fashion with interplanar distances of $c a$. 3.3-3.4 $\AA$. In 5 and $\mathbf{6}$ the aromatic fragments of the isocyanide ligands also take part in these $\pi \cdots \pi$ interactions. Absorption and emission properties of all the complexes 1-9 have been studied and explained with the aid of TDDFT theoretical calculations.

Compounds 1-9 are not emissive in solution but they are in rigid matrix. In glassy 2-Me-THF or $\mathrm{CH}_{2} \mathrm{Cl}_{2}$ at $77 \mathrm{~K}$ the Pt/Ag compounds 4-9 at any concentration $\left(10^{-3} \mathrm{M}\right.$, $10^{-4} \mathrm{M}, 10^{-5} \mathrm{M}$ ) show the same emission spectra as their corresponding starting complexes 1-3, in line with the rupture of the Pt-Ag bonds. In the solid state only the dinuclear compounds $\left[\mathrm{Pt}\left(\mathrm{C}_{6} \mathrm{~F}_{5}\right)(\mathrm{bzq})\left(\mathrm{CN}-{ }^{t} \mathrm{Bu}\right) \mathrm{AgPPh}_{3}\right] \mathrm{ClO}_{4}(7)$ and $\left[\mathrm{Pt}\left(\mathrm{C}_{6} \mathrm{~F}_{5}\right)(\mathrm{bzq})(\mathrm{CN}-\right.$ 2,6- $\left.\mathrm{Me}_{2} \mathrm{Ph}\right) \mathrm{AgPPh}_{3} \mathrm{ClO}_{4}$ (9) together with the tetranuclear complex 
$\left[\left\{\mathrm{Pt}\left(\mathrm{C}_{6} \mathrm{~F}_{5}\right)(\mathrm{bzq})\left(\mathrm{CN}-2,6-\mathrm{Me}_{2} \mathrm{Ph}\right) \mathrm{Ag}\right\}_{2}\right]\left(\mathrm{ClO}_{4}\right)_{2}$ (6) are emissive at room temperature showing bright greenish $(7,9)$ or yellowish (6) phosphorescence. In all three compounds a significant contribution of $\mathrm{M}^{\prime}$ orbitals $\left(\mathrm{AgPPh}_{3} / \mathrm{Ag}\right)$ to the frontier orbitals (FO) has been observed, and their main emissions seem to arise from mixed excited states ${ }^{3} \mathrm{ILCT}\left(\pi-\pi^{*}(\mathrm{bzq})\right) /{ }^{3} \mathrm{MM}^{\prime} \mathrm{LCT}\left(\mathrm{Pt} / \mathrm{AgPPh}_{3} \rightarrow\right.$ bzq) $(7,9)$ or ${ }^{3} \mathrm{LMM}^{\prime} \mathrm{CT}$ $[(\mathrm{bzq}) \rightarrow \mathrm{Pt} / \mathrm{Ag}] /^{3} \mathrm{ILCT}\left[\pi-\pi^{*}(\mathrm{bzq})\right](6)$ in nature.

\section{Keywords}

Metal-metal bond complexes

$\pi \cdots \pi$ intermolecular interactions

$\eta$-Ag-C interactions

Luminescent complexes 


\section{Introduction}

The preparation and study of complexes containing metallophilic interactions between closed or pseudo closed shell transition metals $\left(d^{10}, d^{8}, d^{10} s^{2}\right)$ is for various reasons a field of great interest in Inorganic Chemistry. ${ }^{1-11}$ Metal-metal bonds can act as a link between different subassemblies, making them a valuable tool in molecular or crystal engineering, and giving rise to a variety of structures, from simple linear bimetallic compounds to infinite one-dimensional chains. ${ }^{12-30}$ Furthermore, some of these complexes show interesting photophysical and photochemical properties, ${ }^{1-}$ $5,7,8,11,17,27,29-48$ which in some cases have been exclusively attributed to the presence of metallophilic bonds.

Square planar complexes of Pt(II) have been successfully used as precursors of clusters containing $\mathrm{Pt}(\mathrm{II})\left(\mathrm{d}^{8}\right) \rightarrow \mathrm{M}$ bonds, ${ }^{5,12-17,21,22,26,28-30,46,49-57}$ the acidic $\mathrm{M}$ center being $\mathrm{Cu}(\mathrm{I}), \mathrm{Ag}(\mathrm{I}), \mathrm{Au}(\mathrm{I}), \mathrm{Cd}(\mathrm{II}), \mathrm{Hg}(\mathrm{II}), \mathrm{Tl}(\mathrm{I}), \mathrm{Sn}(\mathrm{II})$ and $\mathrm{Pb}(\mathrm{II})$. In the course of our recent research, we have studied the use of strong ligand field cyclometalated $\mathrm{C}^{\wedge} \mathrm{N}$ ligands, such as 7,8-benzoquinolinate (bzq), in the coordination sphere of the $\mathrm{Pt}$ precursor. ${ }^{13,14,27,47}$ Thus, the use of $\left[\operatorname{Pt}(\mathrm{bzq})\left(\mathrm{C}_{6} \mathrm{~F}_{5}\right)(\mathrm{L})\right]^{\mathrm{n}-}\left(\mathrm{L}=\mathrm{C}_{6} \mathrm{~F}_{5}, \mathrm{n}=1 ;^{13,14,27} \mathrm{~L}=\right.$ $\mathrm{Me}_{2} \mathrm{CO}, \mathrm{PPh}_{3}, \mathrm{pyPh}_{2}$, tht, $\mathrm{MeCN}, \mathrm{n}=0^{30}$ ) allowed us to prepare bimetallic complexes Pt-M (M = Cd, $\left.{ }^{14} \mathrm{Ag}^{13,27,30}\right)$, trimetallic "sandwich" complexes Pt-Ag-Pt, ${ }^{13,30}$ or metallic infinite chain systems $\cdots \mathrm{Pt}-\mathrm{Ag}-\mathrm{Pt}-\mathrm{Ag}-\mathrm{Pt} \cdots \cdot{ }^{27,47}$ The $\mathrm{Pt}-\mathrm{Ag}$ complexes, in addition to the intermetallic bonds, also contain very unusual $\eta^{1}$ bonding interactions between the silver(I) center and the $\mathrm{C}_{i p s o}$ of the bzq ligand and $\pi \cdots \pi$ stacking interactions between the aromatic rings of the bzq ligands are present.

In this paper we describe the syntheses of a family of isocyanide Pt complexes also containing the bzq ligand, $\left[\mathrm{Pt}\left(\mathrm{C}_{6} \mathrm{~F}_{5}\right)(\mathrm{bzq})(\mathrm{CNR})\right]\left\{\mathrm{R}={ }^{t} \mathrm{Bu}\right.$, 2-naphthyl, 2,6$\mathrm{Me}_{2} \mathrm{Ph}$, and their use as precursors of new bi-, tri- and tetranuclear complexes containing Pt-Ag bonds. These clusters have been characterized and studied by X-ray crystallography and NMR spectroscopy. Finally, their optical properties have been investigated and time-dependent density functional theory (TD-DFT) calculations have been performed to gain a better insight into the nature of the electronic transitions.

\section{Results and discussion}

2.1. Synthesis and characterization of the mononuclear complexes $\left[\mathrm{Pt}\left(\mathrm{C}_{6} \mathrm{~F}_{5}\right)(\mathrm{bzq})(\mathrm{CNR})\right]\left\{R={ }^{t} \mathrm{Bu}(1), 2-n a p h t h y l(2), 2,6-M e_{2} \mathrm{Ph}(3)\right\}$ 
Complexes of stoichiometry $\left[\mathrm{Pt}\left(\mathrm{C}_{6} \mathrm{~F}_{5}\right)(\mathrm{bzq}) \mathrm{L}\right]$ have been previously successfully prepared by replacement of the labile acetone ligand in $\left[\mathrm{Pt}\left(\mathrm{C}_{6} \mathrm{~F}_{5}\right)(\mathrm{bzq})\left(\mathrm{Me}_{2} \mathrm{CO}\right)\right]$ with the corresponding ligand L. ${ }^{30,58}$ Thus, the addition of equimolar amounts of the isocyanide $\mathrm{CNR}$ ( $\mathrm{R}={ }^{t} \mathrm{Bu}, 2$-naphthyl, 2,6-Me $\mathrm{e}_{2} \mathrm{Ph}$ ) to acetone solutions of $\left[\mathrm{Pt}\left(\mathrm{C}_{6} \mathrm{~F}_{5}\right)(\mathrm{bzq})\left(\mathrm{Me}_{2} \mathrm{CO}\right)\right]$ at $0^{\circ} \mathrm{C}$ under protective $\mathrm{Ar}$ atmosphere allows to obtain the corresponding complexes $\left[\mathrm{Pt}\left(\mathrm{C}_{6} \mathrm{~F}_{5}\right)(\mathrm{bzq})(\mathrm{CNR})\right]\left\{\mathrm{R}={ }^{t} \mathrm{Bu}\right.$ (1), 2-naphthyl (2), 2,6$\mathrm{Me}_{2} \mathrm{Ph}$ (3) $\}$ as yellow solids which precipitate after partial evaporation of the solvent. (See Experimental).

The IR spectra of complexes 1-3 confirm the replacement of the acetone in the starting material, with the CNR ligands, given that the $v_{\mathrm{CO}}$ vibration band at $1669 \mathrm{~cm}^{-1}$ is absent; and a band at $c a$. $2160 \mathrm{~cm}^{-1}$, corresponding to the isocyanide $v_{\mathrm{CN}}$ vibration is now present in all three cases (see Experimental). The ${ }^{1} \mathrm{H}$ NMR spectra of these complexes also show the signals due to the new ligands, in addition to the ones attributed to the bzq ligand, with the expected relative intensity. The ${ }^{19} \mathrm{~F}$ NMR spectra of 1-3 present the same three-signal pattern expected for a $\mathrm{AA}^{\prime} \mathrm{MM}^{\prime} \mathrm{X}$ system corresponding to the pentafluorophenyl ligand. All the NMR data are compiled in the Experimental section.

The structures of complexes $\mathbf{1}$ and $\mathbf{3}$ have been established by X-ray diffraction studies. Figure 1 shows views of the corresponding complexes and Tables S1 and S2 (Supplementary Material) list a selection of relevant bond distances and angles. In both cases they are square planar complexes with the bzq ligand coplanar to the metal plane. The pentafluorophenyl ligand is in a trans position with respect to the nitrogen atom of the bzq ligand. As previously observed in other platinum(II) complexes containing the bzq ligand ${ }^{13,17,27,30,47,59}$ or other cyclometalated planar ligands. ${ }^{28,29,60}$ the complexes establish a supramolecular arrangement through $\pi \cdots \pi$ interactions of the bzq aromatic ring system of different moieties that stack in a parallel fashion, forming an infinite array with interplanar distances of $c a$. 3.3-3.4 A. In 2 the phenyl ring of the isocyanide ligand is also coplanar to the square metal and bzq planes, and participates in the intermolecular $\pi \cdots \pi$ stacking. (see Figure S1, Supplementary Material). 


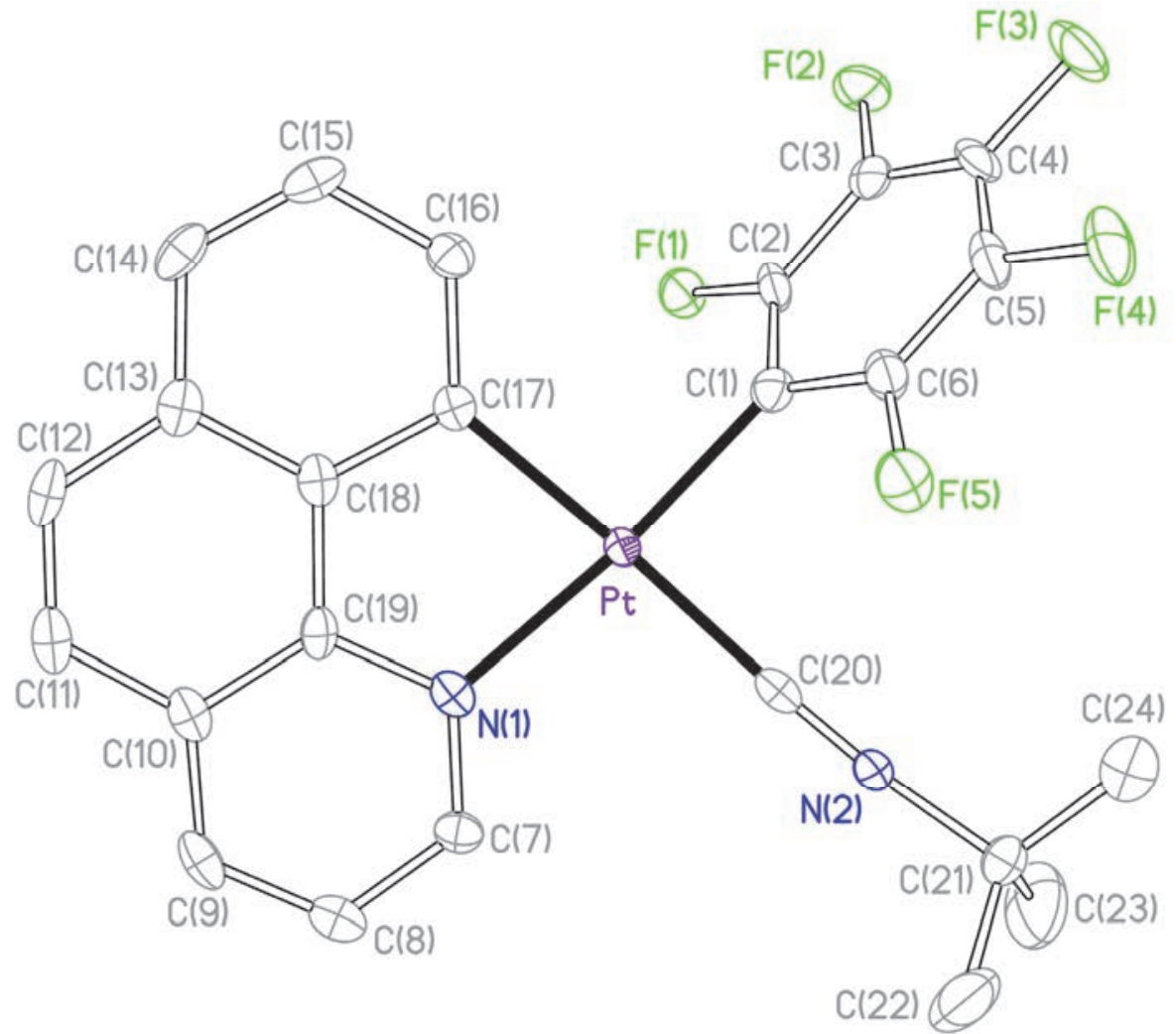

(a)

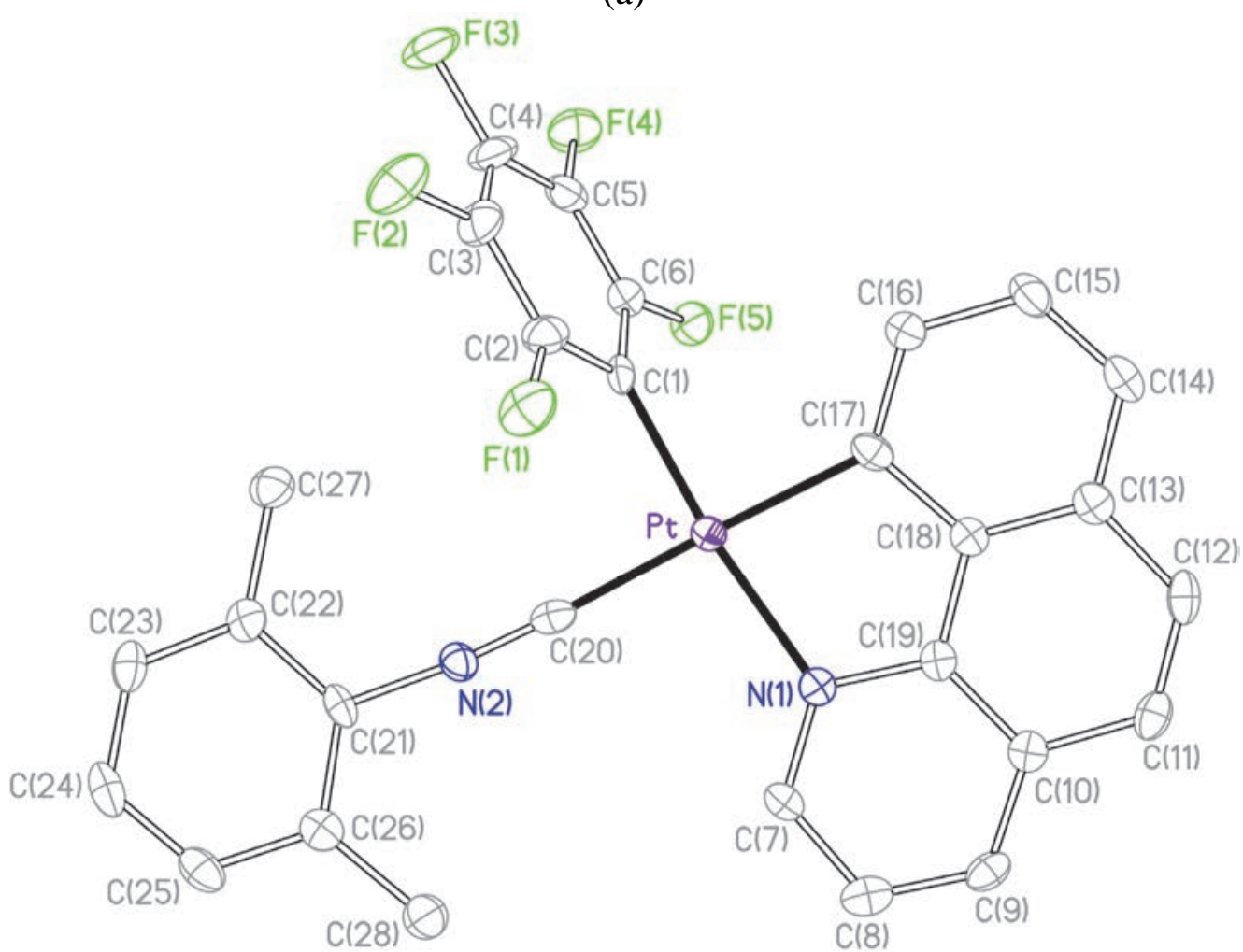

(b)

Figure 1. Views of the molecular structures of the complexes $\left[\mathrm{Pt}\left(\mathrm{C}_{6} \mathrm{~F}_{5}\right)(\mathrm{bzq})\left(\mathrm{CN}^{t} \mathrm{Bu}\right)\right]$ (1).(a) and $\left[\mathrm{Pt}\left(\mathrm{C}_{6} \mathrm{~F}_{5}\right)(\mathrm{bzq})\left(\mathrm{CN}-2,6-\mathrm{Me}_{2} \mathrm{Ph}\right)\right]$ (3) (b). 


\subsection{Reactivity of 1-3 toward $\mathrm{AgClO}_{4}$.}

Although most complexes containing $\mathrm{Pt} \rightarrow \mathrm{Ag}$ bonds have been prepared using anionic Pt(II) precursors, supposedly because of the additional electron density carried by the platinum center, ${ }^{49}$ some results have been obtained using neutral $\mathrm{Pt}(\mathrm{II})$ complexes. $^{28,30,47}$ Thus, we have examined the reactions of complexes 1-3 toward the silver salt $\mathrm{AgClO}_{4}$ with the aim of achieving heterometallic $\mathrm{Pt} \rightarrow \mathrm{Ag}$ complexes.

Different $\mathrm{Pt}(\mathrm{II}) / \mathrm{Ag}(\mathrm{I})$ ratios in the reagents could lead to different nuclearity of the resulting complexes and, for this reason, we investigated the reactivity of 1-3 toward $\mathrm{AgClO}_{4}$ in either $1: 1$ or 2:1 molar ratios. However the same results were obtained regardless of the ratio used. Thus, when the starting materials are complexes $\mathbf{1}$ and $\mathbf{2}$, the reactions take place in a 2:1 molar ratio and the trinuclear complexes $\left[\left\{\mathrm{Pt}\left(\mathrm{C}_{6} \mathrm{~F}_{5}\right)(\mathrm{bzq})(\mathrm{CNR})\right\}_{2} \mathrm{Ag}\right] \mathrm{ClO}_{4}\left\{\mathrm{R}={ }^{t} \mathrm{Bu}(4), 2\right.$-naphthyl (5) $\}$ are obtained. When the starting material is 3 , a tetranuclear complex $\left[\left\{\mathrm{Pt}\left(\mathrm{C}_{6} \mathrm{~F}_{5}\right)(\mathrm{bzq})(\mathrm{CN}-2,6-\right.\right.$ $\left.\left.\left.\mathrm{Me}_{2} \mathrm{Ph}\right) \mathrm{Ag}\right\}_{2}\right]\left(\mathrm{ClO}_{4}\right)_{2}(\mathbf{6})$, which requires a 1:1 molar ratio, is formed. In all three cases, the use of a different $\mathrm{Pt}(\mathrm{II}) / \mathrm{Ag}(\mathrm{I})$ ratio in the starting materials only leads to complexes 4-6 and the corresponding unreacted leftovers.

The ${ }^{1} \mathrm{H}$ NMR spectra of complexes 4-6 show the signals of the corresponding isocyanide ligand besides the ones attributed to the bzq ligand with the expected relative intensity. The ${ }^{19} \mathrm{~F}$ NMR spectra of 4-6 present only one set of signals indicating the equivalence of the pentafluorophenyl groups of the two " $\mathrm{Pt}\left(\mathrm{C}_{6} \mathrm{~F}_{5}\right)(\mathrm{bzq}) \mathrm{L}$ " subunits. The pattern of the signals is similar to that described above for complexes 1-3. All these NMR data are compiled in the Experimental section.

Neither the IR nor the NMR spectra are informative of the structure (tri-or tetranuclear) of complexes 4-6. These structures have been established by X-ray diffraction studies. Figures 2-4 show views of the corresponding complexes and Tables 1-3 list a selection of relevant bond distances and angles. Complex 4 has been found to crystallize in two pseudo-polymorphs ${ }^{61}$ witch are different in the crystallization solvent incorporated to the lattice (see Figure 2). In the case of 4a there are two dichloromethane molecules that do not play any structural role, while $\mathbf{4 b}$ includes acetone, and in this case, one of the $\mathrm{Me}_{2} \mathrm{CO}$ moieties is linked to the Ag center through an Ag-O bond. The coordination of the acetone molecule causes some variations in the intermetallic distances that will be discussed later. 


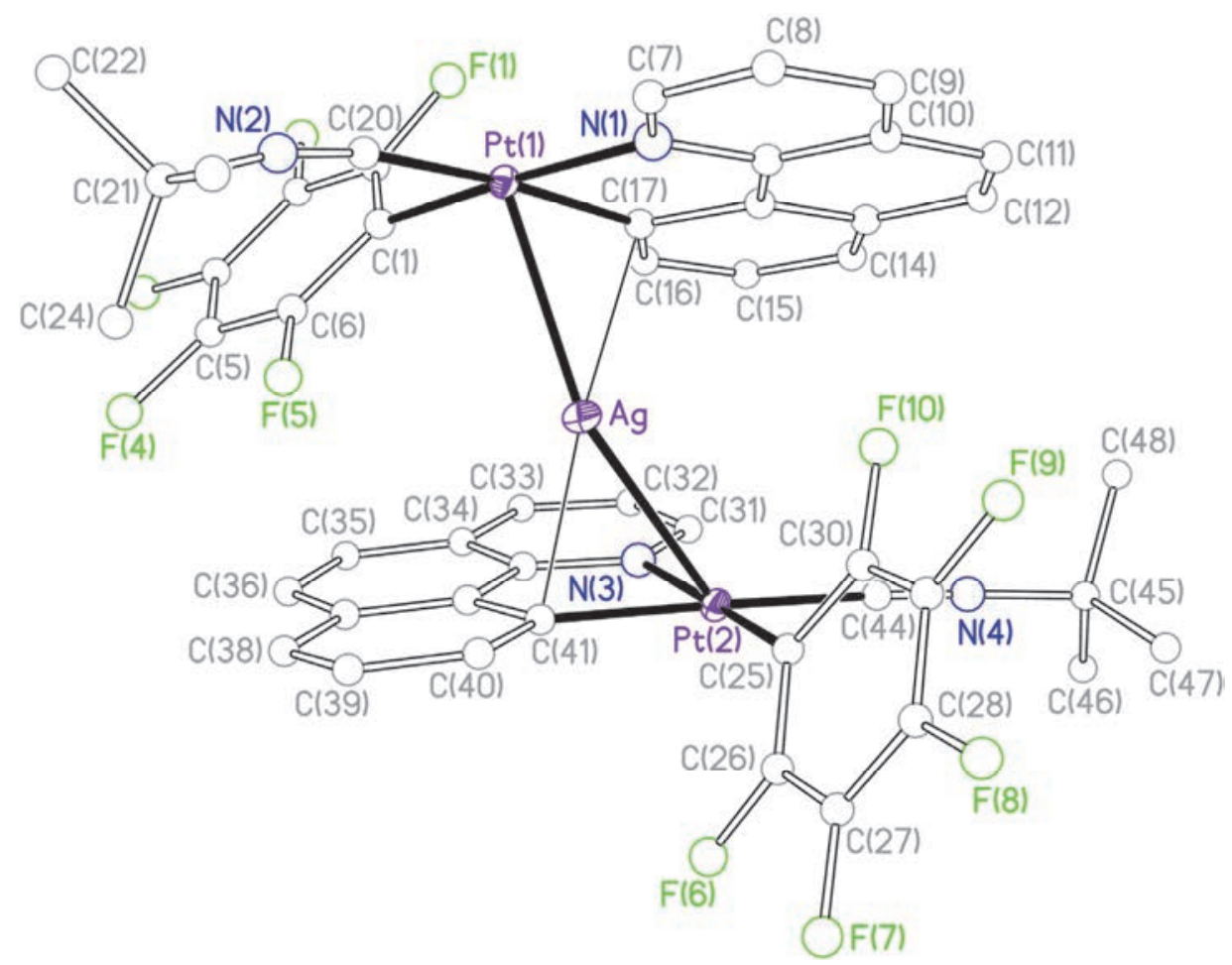

a)

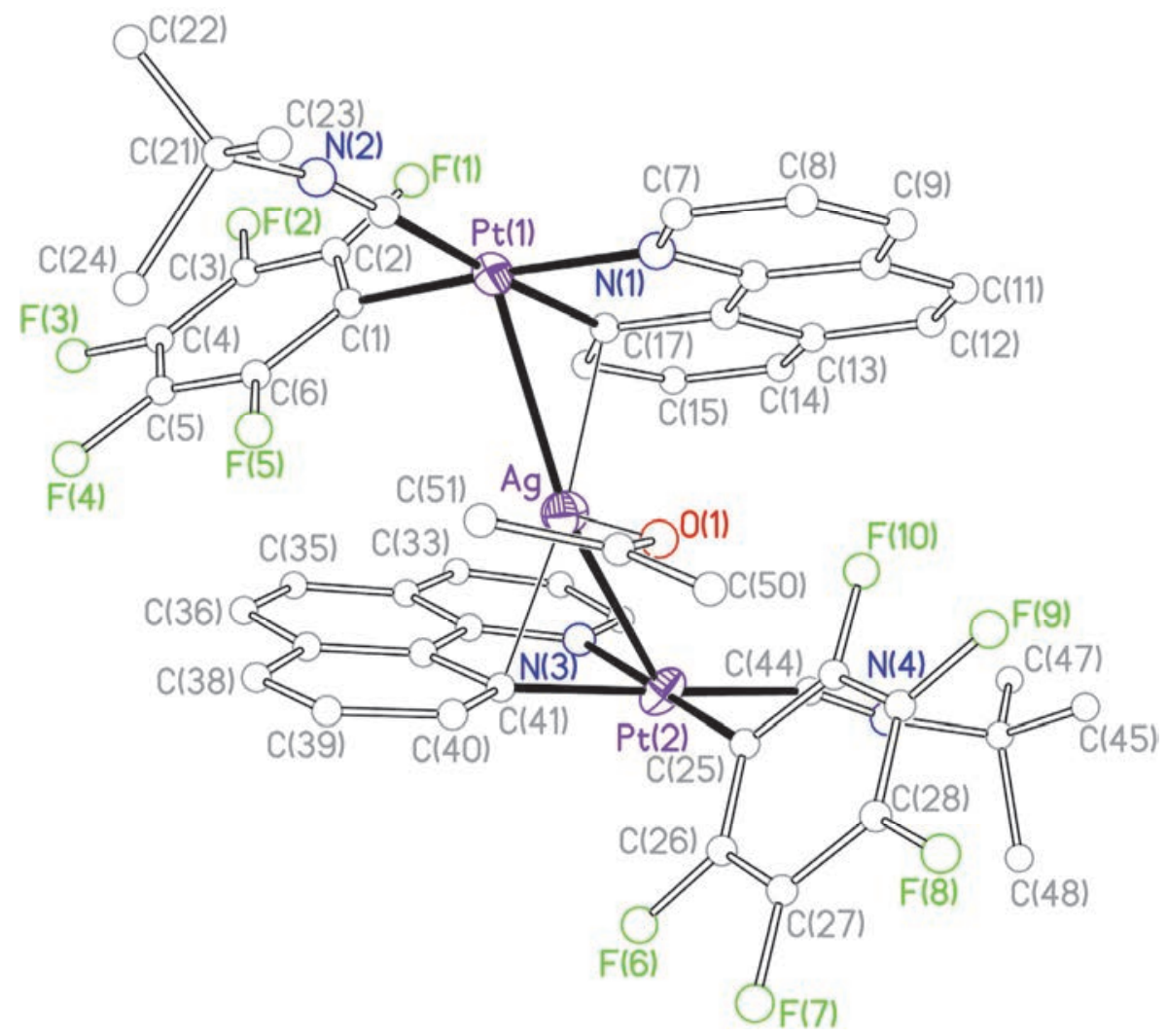

b)

Figure 2. Views of the molecular structures of the cations of the complexes a) $\left[\left\{\mathrm{Pt}\left(\mathrm{C}_{6} \mathrm{~F}_{5}\right)(\mathrm{bzq})\left(\mathrm{CN}^{t} \mathrm{Bu}\right)\right\}_{2} \mathrm{Ag} \mathrm{ClO}_{4}(\mathbf{4 a})\right.$ and b) $\left[\left\{\mathrm{Pt}\left(\mathrm{C}_{6} \mathrm{~F}_{5}\right)(\mathrm{bzq})\left(\mathrm{CN}^{t} \mathrm{Bu}\right)\right\}_{2} \mathrm{Ag}\left(\mathrm{Me}_{2} \mathrm{CO}\right)\right]$ $\mathrm{ClO}_{4}(\mathbf{4 b})$. 


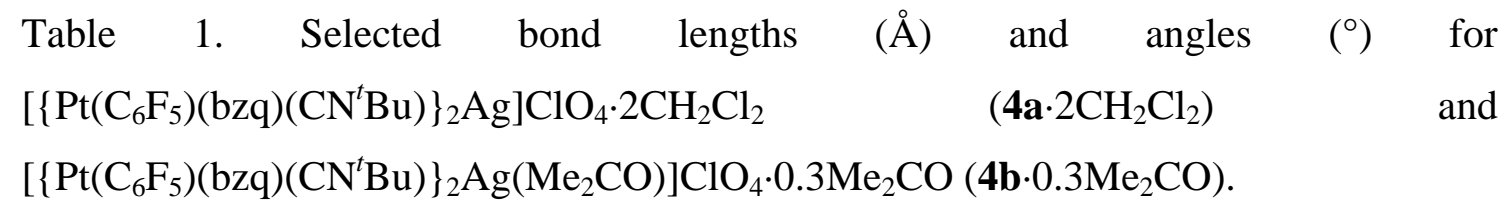

\begin{tabular}{lrr}
\hline & $\mathbf{4 a} \cdot 2 \mathrm{CH}_{2} \mathrm{Cl}_{2}$ & $\mathbf{4 b} \cdot 0.3 \mathrm{Me}_{2} \mathrm{CO}$ \\
\hline $\operatorname{Pt}(1)-\mathrm{Ag}$ & $2.7158(3)$ & $2.8638(4)$ \\
$\operatorname{Pt}(2)-\mathrm{Ag}$ & $2.7791(3)$ & $2.9437(4)$ \\
$\operatorname{Pt}(1)-\mathrm{C}(20)$ & $1.987(3)$ & $1.981(6)$ \\
$\operatorname{Pt}(1)-\mathrm{C}(1)$ & $2.026(3)$ & $2.026(5)$ \\
$\operatorname{Pt}(1)-\mathrm{C}(17)$ & $2.029(3)$ & $2.042(5)$ \\
$\operatorname{Pt}(1)-\mathrm{N}(1)$ & $2.083(2)$ & $2.081(4)$ \\
$\operatorname{Pt}(2)-\mathrm{C}(44)$ & $1.984(3)$ & $1.971(6)$ \\
$\operatorname{Pt}(2)-\mathrm{C}(25)$ & $2.024(3)$ & $2.030(4)$ \\
$\operatorname{Pt}(2)-\mathrm{C}(41)$ & $2.049(3)$ & $2.046(5)$ \\
$\operatorname{Pt}(2)-\mathrm{N}(3)$ & $2.089(2)$ & $2.081(4)$ \\
$\operatorname{Ag}-\mathrm{C}(41)$ & $2.347(3)$ & $2.369(4)$ \\
$\operatorname{Ag}-\mathrm{C}(17)$ & $2.450(3)$ & $2.373(5)$ \\
$\operatorname{Ag}-\mathrm{O}(1)$ & - & $2.451(3)$ \\
$\mathrm{C}(41)-\mathrm{Ag}-\mathrm{C}(17)$ & $146.66(10)$ & $134.42(16)$ \\
$\operatorname{Pt}(1)-\mathrm{Ag}-\mathrm{Pt}(2)$ & $159.70(1)$ & $155.79(2)$ \\
\hline
\end{tabular}

Both polymorphs $\mathbf{4 a} / \mathbf{b}$ and $\mathbf{5}$ are trinuclear $\mathrm{Pt}-\mathrm{Ag}-\mathrm{Pt}$ complexes with a "sandwich" disposition. In all three cases, two " $\mathrm{Pt}\left(\mathrm{C}_{6} \mathrm{~F}_{5}\right)(\mathrm{bzq})(\mathrm{CNR})$ " fragments are linked by a silver atom through $\mathrm{Pt} \rightarrow \mathrm{Ag}$ bonds. As expected, the $\mathrm{Pt}$ is at the center of a square planar environment, which is essentially coplanar with its bzq ligand. The Pt-Ag distances are 2.7158(3) and 2.7791(3) $\AA$ in 4a, 2.8638(4) and 2.9437(4) $\AA$ in 4b, and 2.8624(3) and 2.8387(4) $\AA$ in 5. All these values are in the range found for other complexes containing $\mathrm{Pt} \rightarrow \mathrm{Ag}$ bonds. ${ }^{12,13,19,20,26-28,30,49,62-69}$ It is noteworthy that the PtAg bond distances are perceptively shorter for $\mathbf{4 a}$ than for $\mathbf{4 b}$ or $\mathbf{5}$. As previously indicated the main difference between the two polymorphs $\mathbf{4 a}$ or $\mathbf{4 b}$ arises from the solvents used in the preparation of the crystals suitable for X-ray studies, and that cause one acetone molecule to be bonded to the silver center through its oxygen atom, with a Ag-O(1) distance of 2.451(3) A. This distance is in the range found in similar systems 
also containing $\mathrm{Pt} \rightarrow \mathrm{Ag}$ bonds. ${ }^{26,27,47}$ Besides, in $\mathbf{5}$ the $\mathrm{Ag}$ atom also interacts with an oxygen atom, this time belonging to the perchlorate anion, with a $\mathrm{Ag}-\mathrm{O}(1)$ distance of 2.548(9) A. Thus, it seems that the addition of a third bond in the coordination sphere of the silver center causes a weakening of the Pt-Ag bonds, which is reflected in the intermetallic distance, as it has been previously observed. ${ }^{13,30}$

As has been described for similar sandwich complexes containing bzq or other planar cyclometallated ligands, ${ }^{13,26-28,30}$ in addition to the Pt-Ag bonds, the silver center also establishes a short $\eta^{1}$ interaction with the $C_{i p s o}$ of the bzq ligands, with Ag-C distances 2.347(3) and 2.450(3) Å for 4a, 2.369(4) and 2.373(5) $\AA$ for $\mathbf{4 b}$ and 2.488(4) and 2.546(5) $\AA$ for 5. These $\eta^{1}$-Ag-C along the $\mathrm{Pt} \rightarrow \mathrm{Ag}$ bonds fulfill the electron density requirements of the acidic silver center. Ag-C lines are usually perpendicular to the aromatic planar ring system, which is also observed to a greater or lesser extent in 4a/b and 5, given the geometric limitations imposed by the Pt-Ag bonds. Thus, the angles between the Ag-C lines and the perpendicular to the best bzq planes are $18.4(1)^{\circ}$ and $16.4(1)^{\circ}$ for $\mathbf{4 a}, 14.2(1)^{\circ}$ and $15.1(1)^{\circ}$ for $\mathbf{4 b}$, and $21.1(1)^{\circ}$ and $23.1(1)^{\circ}$ for 5 .

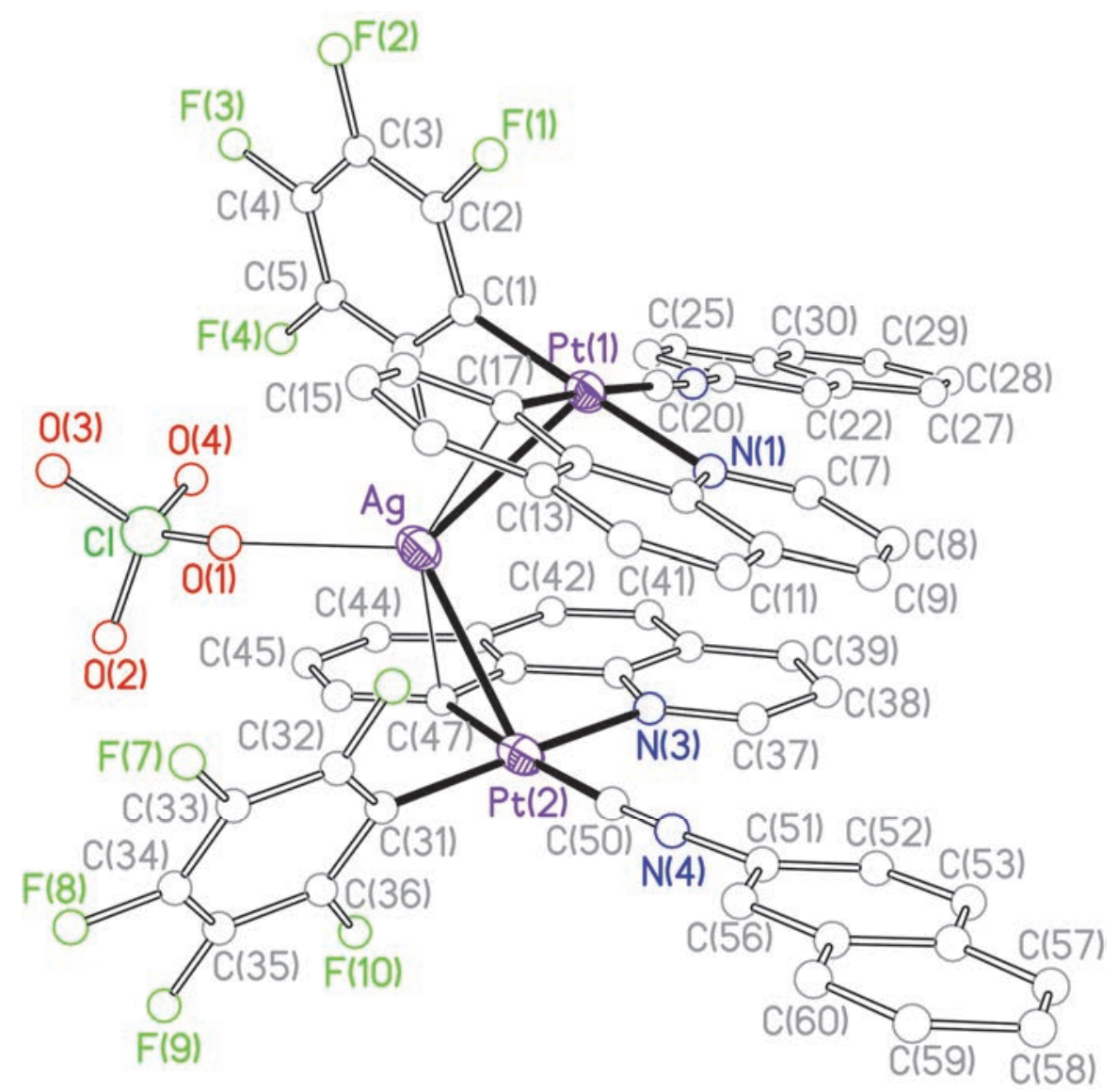

Figure 3. View of the molecular structure of the compound $\left[\left\{\operatorname{Pt}\left(\mathrm{C}_{6} \mathrm{~F}_{5}\right)(\mathrm{bzq})(\mathrm{CN}-2-\right.\right.$ naphthyl) $\}_{2} \mathrm{Ag}_{\mathrm{ClO}}(\mathbf{5})$. 
Table 2. Selected bond lengths $(\AA)$ and angles $\left(^{\circ}\right)$ for $\left[\left\{\operatorname{Pt}\left(\mathrm{C}_{6} \mathrm{~F}_{5}\right)(\mathrm{bzq})(\mathrm{CN}-2-\right.\right.$ naphthyl) $\left.\}_{2} \mathrm{Ag}\right] \mathrm{ClO}_{4} \cdot 0.9 \mathrm{Me}_{2} \mathrm{CO}\left(5 \cdot 0.9 \mathrm{Me}_{2} \mathrm{CO}\right)$

\begin{tabular}{lrlr}
$\operatorname{Pt}(1)-\mathrm{C}(20)$ & $1.970(5)$ & $\mathrm{Pt}(1)-\mathrm{C}(1)$ & $2.028(4)$ \\
$\operatorname{Pt}(1)-\mathrm{C}(17)$ & $2.037(4)$ & $\mathrm{Pt}(1)-\mathrm{N}(1)$ & $2.082(3)$ \\
$\operatorname{Pt}(1)-\mathrm{Ag}$ & $2.8624(3)$ & $\mathrm{Pt}(2)-\mathrm{C}(50)$ & $1.970(5)$ \\
$\operatorname{Pt}(2)-\mathrm{C}(31)$ & $2.020(5)$ & $\mathrm{Pt}(2)-\mathrm{C}(47)$ & $2.040(5)$ \\
$\operatorname{Pt}(2)-\mathrm{N}(3)$ & $2.101(4)$ & $\mathrm{Pt}(2)-\mathrm{Ag}$ & $2.8387(4)$ \\
$\mathrm{Ag}-\mathrm{C}(17)$ & $2.488(4)$ & $\mathrm{Ag}-\mathrm{C}(47)$ & $2.546(5)$ \\
$\mathrm{Ag}-\mathrm{O}(1)$ & $2.548(9)$ & & \\
$\mathrm{C}(17)-\mathrm{Ag}-\mathrm{C}(47)$ & $148.14(15)$ & $\mathrm{Pt}(2)-\mathrm{Ag}-\mathrm{Pt}(1)$ & $106.825(11)$ \\
\hline
\end{tabular}

A remarkable structural difference between the structures of $\mathbf{4}$ and $\mathbf{5}$ is the Pt-AgPt angle. Thus, while in $\mathbf{4 a}$ and $\mathbf{4 b}$ these angles are $159.70(1)^{\mathbf{0}}$ and $155.79(2)^{\mathbf{o}}$ respectively, in 5 the value is much narrower, $106.83(1)^{\circ}$. The structural flexibility of these types of complexes containing Pt-M bonds have been previously observed ${ }^{13,69}$ and seems also to be related to the occurrence of polymorphism in the structures of these systems. $^{13,61}$

There are two possible relative dispositions of the " $\mathrm{Pt}\left(\mathrm{C}_{6} \mathrm{~F}_{5}\right)(\mathrm{bzq})(\mathrm{CNR})$ " fragments to each other in these "sandwich type" Pt-Ag-Pt complexes: "eclipsed" (Scheme 1A) or "alternate" (Scheme 1B). In this scheme, the possible relative rotation of both Pt planes around the Pt-Pt line has not been considered for the sake of simplicity. These two conformations have been previously found in similar complexes containing the bzq and $\mathrm{C}_{6} \mathrm{~F}_{5}$ ligands. ${ }^{13,27,30}$ The two possible conformations are present in the complexes described here. In the two polymorphs of $\mathbf{4}$ all the relative positions of the atoms bonded to both Pt atoms coincide (Scheme 1A), while in 5, these positions are alternated (Scheme 1B). Another way in which the geometry of these complexes varies their geometry is the rotation of one square planar Pt environment in relation to the other. Thus, in the two polymorphs of $\mathbf{4}$, the torsion angles $\mathrm{C}_{i p s o \mathrm{C}_{65} 5}-\mathrm{Pt}-\mathrm{Pt}-\mathrm{C}_{i p s o \mathrm{C} 6 \mathrm{F5}}$ are around $145^{\circ}$, while in 5 it is only $53.5^{\circ}$. All these different conformations are again proof of the flexibility of this kind of complexes and they are most likely caused by the steric effects introduced by the bulky ligands bonded to the platinum centers, as well as by the packing forces operating in the crystal environment. 


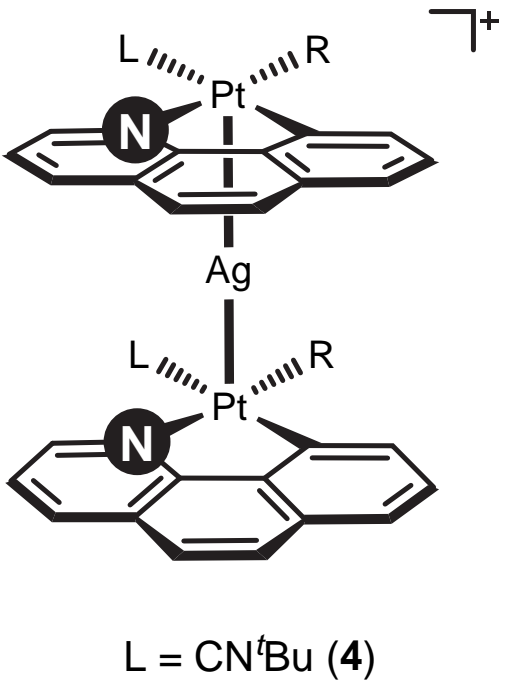

A

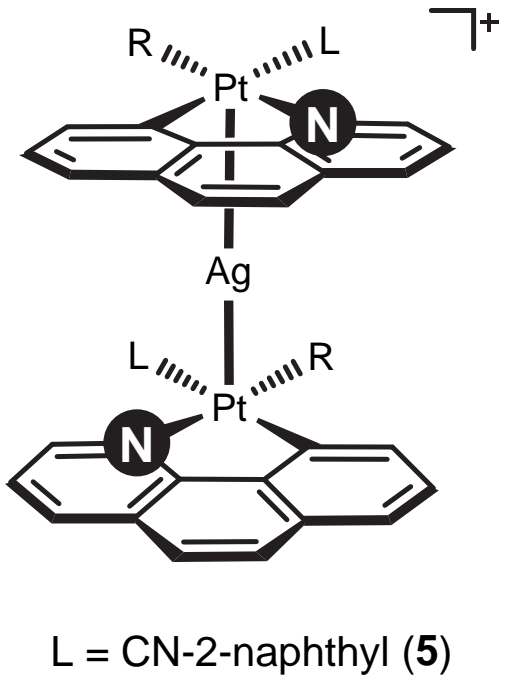

B

Scheme 1. Relative dispositions of the " $\mathrm{Pt}\left(\mathrm{C}_{6} \mathrm{~F}_{5}\right)(\mathrm{bzq})(\mathrm{CNR})$ " fragments in "sandwich type” Pt-Ag-Pt complexes

The X-ray studies on $\mathbf{4}$ and $\mathbf{5}$ have shown supramolecular arrangements through $\pi \cdots \pi$ interactions established by the planar bzq ligands. In the case of $\mathbf{4 a} \mathbf{a} \mathbf{b}$, the complexes stack in an infinite array with interplanar distances of ca. 3.4-3.5 $\AA$. In the case of 5 the presence of the aromatic planar rings of the naphtyl are also involved in the $\pi \cdots \pi$ interactions, resulting in a more complicated structure, but one which basically has a two dimensional sheet arrangement.

As previously indicated, $\mathbf{6}$ is a tetranuclear complex that corresponds to the formula $\left[\left\{\mathrm{Pt}\left(\mathrm{C}_{6} \mathrm{~F}_{5}\right)(\mathrm{bzq})\left(\mathrm{CN}-2,6-\mathrm{Me}_{2} \mathrm{Ph}\right) \mathrm{Ag}\right\}_{2}\right]\left(\mathrm{ClO}_{4}\right)_{2}$, as can be seen in Figure 4. For description purposes, the cation of complex 6 can be regarded as a the union of two “( $\left(\mathrm{C}_{6} \mathrm{~F}_{5}\right)(\mathrm{bzq})\left(\mathrm{CN}-2,6-\mathrm{Me}_{2} \mathrm{Ph}\right) \mathrm{PtAg}$ ” subunits, each containing a $\mathrm{Pt} \rightarrow \mathrm{Ag}$ bond, related by an inversion center, and held together through $\eta$ interactions established by the silver atom of one unit and one of the aromatic rings of the bzq ligand of the other. Due to symmetry constraints both square planar Pt environments are strictly parallel. The PtAg distances are 2.7499(3) $\AA$, in the lower range found for this kind of complexes. 12,13,19,20,26-28,30,49,62-69 Each silver center completes its coordination sphere establishing an interaction with the bzq ligand bonded to the other Pt atom. This interaction seems similar in nature to those described for $\mathbf{4}$ and $\mathbf{5}$, and to other similar sandwich complexes ${ }^{13,26-28,30}$ but in the case of $\mathbf{6}$ the shorter Ag-C distance (2.433(3) $\AA$ ) 
corresponds to the carbon atom adjacent to the bzq $\mathrm{C}_{i p s o}(\mathrm{C}(16))$, also with a relatively short distance involving this $\mathrm{C}_{i p s o}(\mathrm{C}(17), 2.516(3) \AA)$. These structural parameters seem to point in this case to a di-hapto Ag-bzq interaction, a common feature found for complexes containing silver and aromatic rings. ${ }^{12,70-72}$ The absence of a second Pt-Ag bond for the silver center could be responsible for this di-hapto configuration versus the mono-hapto found in the trinuclear sandwich complexes. This could also be the cause of the Pt-Ag line in $\mathbf{6}$ being nearly perpendicular to the best Pt square plane, the value of the angle formed by the intermetallic line and the line perpendicular to best Pt plane being only $8.0(1)^{\circ}$ (compared to values ranging from $27.5(1)^{\circ}$ to $39.1(1)^{\circ}$ for $\mathbf{4 a} / \mathbf{b}$ and 5). Moreover, the Ag environments are close to linearity, with a Pt-Ag-C(16') angle of $166.0(1)^{\circ}$.

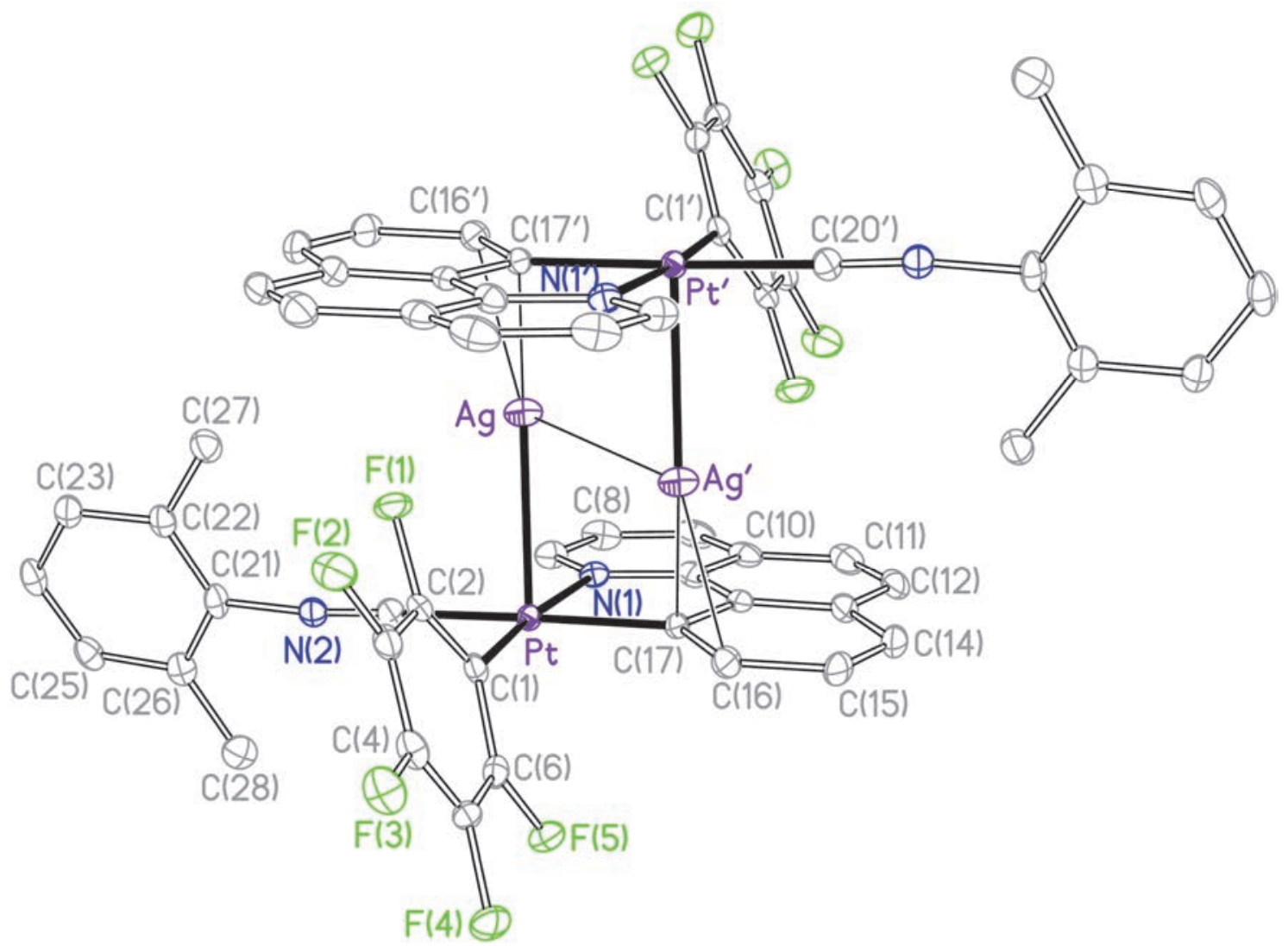

Figure 4. View of the molecular structure of the cation of the complex $\left[\left\{\mathrm{Pt}\left(\mathrm{C}_{6} \mathrm{~F}_{5}\right)(\mathrm{bzq})\left(\mathrm{CN}-2,6-\mathrm{Me}_{2} \mathrm{Ph}\right) \mathrm{Ag}\right\}_{2}\right]\left(\mathrm{ClO}_{4}\right)_{2}(\mathbf{6})$. 
Table 3. Selected bond lengths $(\AA)$ and angles $\left(^{\circ}\right)$ for $\left[\left\{\operatorname{Pt}\left(\mathrm{C}_{6} \mathrm{~F}_{5}\right)(\mathrm{bzq})(\mathrm{CN}-2,6-\right.\right.$ $\left.\left.\left.\mathrm{Me}_{2} \mathrm{Ph}\right) \mathrm{Ag}\right\}_{2}\right]\left(\mathrm{ClO}_{4}\right)_{2}(\mathbf{6})$

\begin{tabular}{lrlr} 
Pt-C(20) & $1.990(3)$ & Pt-C(1) & $2.029(4)$ \\
Pt-C(17) & $2.034(3)$ & Pt-N(1) & $2.083(3)$ \\
Pt-Ag & $2.7499(3)$ & Ag-C(16') & $2.433(3)$ \\
Ag-C(17') & $2.516(3)$ & Ag-Ag' & $2.8811(5)$ \\
C(16')-Ag-Pt & $166.00(8)$ & C(17')-Ag-Pt & $146.23(8)$ \\
\hline
\end{tabular}

Symmetry transformation used to generate equivalent primed atoms is $-\mathrm{x},-\mathrm{y},-\mathrm{z}$.

All these distances and angles seem to indicate a less strained configuration of the " $\mathrm{Pt}_{2} \mathrm{Ag}_{2}$ " core in $\mathbf{6}$ than the " $\mathrm{Pt}_{2} \mathrm{Ag}$ " cores in $\mathbf{4 a} \mathbf{a} \mathbf{b}$ and $\mathbf{5}$. The choice between a tetra- or a trinuclear structure might be driven by steric factors. If the spatial requirements of the 2,6-dimethylphenyl fragment of the isocyanide ligand of $\mathbf{6}$ are higher than the equivalent ${ }^{t} \mathrm{Bu}$ or 2-naphthyl in $\mathbf{4}$ or $\mathbf{5}$, a " $\mathrm{Pt}_{2} \mathrm{Ag}_{2}$ " configuration allows for a bigger separation of the fragment from the core of the complex thus avoiding steric repulsions.

A few " $\mathrm{Pt}_{2} \mathrm{Ag}_{2}$ sandwiches ” containing Pt-Ag bonds have been reported. ${ }^{12,47,73-76}$ Of these it is only in complex [Pt(2,3-bis(2,6-dichlorophenylimino)butane) $\mathrm{Me}_{2}$ $\left.\mathrm{Ag}\left(\mathrm{SO}_{3} \mathrm{CF}_{3}\right)\right]_{2}{ }^{12}$ that each silver center is simultaneously bonded to the two Pt atoms, with similar Pt-Ag distances (2.829, $2.910 \AA$ ), the " $\mathrm{Pt}_{2} \mathrm{Ag}_{2}$ " core forming a rhombus, and no ligand acting as a bridge between Pt and Ag. In all the other cases, the silver is bonded to a ligand of the Pt center and in all cases except one ${ }^{47}$ the two distances of the one silver center to each of the Pt are clearly different, in some cases excluding any intermetallic interaction.

The distance between the two silver atoms is short, Ag-Ag’ 2.8811(5) $\AA$, and it is typical of intermetallic interactions between silver centers ${ }^{12,73}$ for which the term "argentophilia” has been used. ${ }^{12}$ The perchlorate cations are also relatively near the silver centers, in such a way that two of the oxygen atoms establish weak interactions, Ag-O distances being 2.718(3) $\AA$ in both cases.

With respect to the intermolecular arrangement of $\mathbf{6}$, the tetranuclear complexes pack in an infinite array held together though $\pi \cdots \pi$ interactions established by parallel 
bzq ligands of adjacent moieties, the bzq interplanar distances being 3.3-3.4 $\AA$. Furthermore, the aromatic rings of the 2,6-dimethylphenyl fragment of the isocyanide ligands also establish $\pi \cdots \pi$ interactions (3.5 $\AA$ ) connecting adjacent arrays, finally giving rise to a bi-dimensional arrangement of sheets in the crystal structure (see Figure S2, Supplementary Information).

\subsection{Reactivity of 1-3 toward [Ag(OClO 3$\left.)\left(\mathrm{PPh}_{3}\right)\right]$.}

We have explored the reaction of complexes 1-3 toward the silver reagent $\left[\mathrm{Ag}\left(\mathrm{OClO}_{3}\right)\left(\mathrm{PPh}_{3}\right)\right]$ with the aim of preparing the dinuclear complexes $\left[\mathrm{Pt}(\mathrm{bzq})\left(\mathrm{C}_{6} \mathrm{~F}_{5}\right)(\mathrm{CNR}) \mathrm{Ag}\left(\mathrm{PPh}_{3}\right)\right] \mathrm{ClO}_{4}$, containing $\mathrm{Pt} \rightarrow \mathrm{Ag}$ bonds. This synthetic strategy is well known and has been used before with positive results. ${ }^{13,49,65,69}$

Thus, complexes 1-3 were reacted with $\left[\mathrm{Ag}\left(\mathrm{OClO}_{3}\right)\left(\mathrm{PPh}_{3}\right)\right]$ in 1:1 molar ratio in $\mathrm{CH}_{2} \mathrm{Cl}_{2}$ at $0^{\circ} \mathrm{C}$ and in an $\mathrm{Ar}$ atmosphere. After $30 \mathrm{~min}$ of stirring in absence of light, the solution was concentrated until ca. $2 \mathrm{~mL}$, and the resulting suspension treated with $n$ hexane, giving rise to yellow solids that were filtered off and air-dried. These solid were identified (see below) as $\left[\left(\mathrm{C}_{6} \mathrm{~F}_{5}\right)(\mathrm{bzq})(\mathrm{CNR}) \mathrm{PtAg}\left(\mathrm{PPh}_{3}\right)\right] \mathrm{ClO}_{4}\left\{\mathrm{R}={ }^{t} \mathrm{Bu},(7)\right.$, 2-naphthyl (8), 2,6- $\left.\mathrm{Me}_{2} \mathrm{Ph}(\mathbf{9})\right\}$.

The IR spectra of 7-9 show, in all cases, the presence of bands caused by the bzq, $\mathrm{PPh}_{3}, \mathrm{C}_{6} \mathrm{~F}_{5}$ and CNR ligands, and the perchlorate anion. The ${ }^{1} \mathrm{H}$ and ${ }^{19} \mathrm{~F}$ NMR spectra are very similar to those described above for 1-6, with the addition of the $\mathrm{PPh}_{3}$ signals in the ${ }^{1} \mathrm{H}$ NMR in the form of complex signals that conceal some of the signals of the CNR ligands in the case of $\mathbf{8}$ and $\mathbf{9}$ (see Experimental).

The ${ }^{31} \mathrm{P}$ NMR spectra at room temperature show in all cases a broad doublet signal centered at about $14 \mathrm{ppm}$. The splitting is caused by the coupling with the Ag center, and the coupling constant value is around $700 \mathrm{~Hz}$ (see Experimental), consistent with the existence of a Ag-P bond. ${ }^{77}$ The low resolution of the signals does not the coupling caused by the two silver NMR active isotopes $\left({ }^{107} \mathrm{Ag}, 51.8 \%\right.$ abundance and ${ }^{109} \mathrm{Ag}$, $48.2 \%$ abundance) to be distinguished. In any case, no signal corresponding to the presence of a $\mathrm{Pt}-\mathrm{P}$ bond is detected, and thus a migration of the $\mathrm{PPh}_{3}$ from the silver to the platinum center can be ruled out. ${ }^{30}$ 


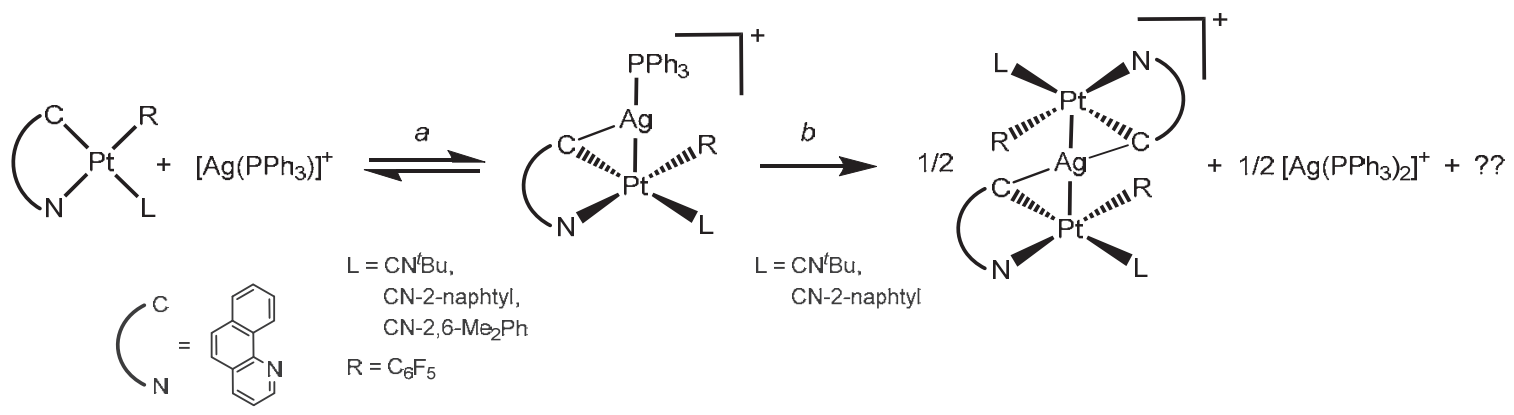

Scheme 2. Solution behaviour of complexes 7-9.

Nevertheless, the ${ }^{31} \mathrm{P}$ NMR spectra of these samples recorded at $193 \mathrm{~K}$ show a more complicated pattern of two doublets of doublets of different intensity. The more intense one is attributed to the complexes $\mathbf{7 - 9}$, and is caused by the coupling of the ${ }^{31} \mathrm{P}$ nucleus to the two silver NMR active isotopes that are distinguishable at this low temperature. The other doublet of doublets has been identified as being due to $\left[\mathrm{Ag}\left(\mathrm{OClO}_{3}\right)\left(\mathrm{PPh}_{3}\right)\right]$. At intermediate temperatures a reversible transformation of the low temperature and room temperature spectra is observed. These data seem to indicate that in solution, there are equilibrium processes which involve the rupture and formation of Pt-Ag bonds (Scheme 2a). In accordance with this hypothesis, when the NMR spectra of mixtures of either 7-9 with $\left[\mathrm{Ag}\left(\mathrm{OClO}_{3}\right)\left(\mathrm{PPh}_{3}\right)\right]$ or 7-9 with their corresponding starting materials 1-3 are recorded at room temperature, only one set of signals is found, slightly displaced, indicating that the components of the mixture participate in an equilibrium faster than the NMR time scale.

On the other hand, when solutions of 7-9 are stirred for a long time (72 h) at room temperature, the solids that are obtained after work up of the solutions are identified (NMR) as a complex mixture. In the case of the complexes that contain $\mathrm{CN}^{t} \mathrm{Bu}(7)$ or CN-2-naphthyl (8) among the components of this mixture, these dinuclear clusters, the sandwich trinuclear complexes $\left[\left\{\mathrm{Pt}_{(}\left(\mathrm{C}_{6} \mathrm{~F}_{5}\right)(\mathrm{bzq})(\mathrm{CNR})\right\}_{2} \mathrm{Ag}\right] \mathrm{ClO}_{4} \quad\left\{\mathrm{R}={ }^{t} \mathrm{Bu}\right.$ (4), 2naphthyl (5) $\}$ and $\left[\mathrm{Ag}\left(\mathrm{PPh}_{3}\right)_{2}\right] \mathrm{ClO}_{4}$ can be identified, besides some unknown compounds containing $\mathrm{Pt}-\mathrm{PPh}_{3}$ bonds. In the case of the complex with $\mathrm{CN}-2,6-\mathrm{Me}_{2} \mathrm{Ph}$ (9) no information could be extracted from the NMR of the mixture. Thus, in the case of the $\mathrm{CN}^{t} \mathrm{Bu}$ (7) or $\mathrm{CN}-2$-naphthyl (8) ligands, the trinuclear complexes 4 and 5 seem to be more stable than their corresponding dinuclear counterparts, $\mathbf{7}$ and $\mathbf{8}$, with the 
phosphine ligand completing the coordination sphere of the silver center (Scheme 2b). This behaviour has already been observed. ${ }^{30}$

The higher stability of the trinuclear complexes vs the dinuclear ones is supported by the fact that when solutions of $\mathbf{7}$ in dichloromethane are stored for several weeks in the refrigerator for the purpose of obtaining suitable crystals for X-ray studies two different types of crystalline specimens are obtained. One of them was identified as the trinuclear polymorph 4a by measuring the unit cell ( $\mathrm{X}$ ray), whereas in the others the dinuclear complex $\left[\left(\mathrm{C}_{6} \mathrm{~F}_{5}\right)(\mathrm{bzq})\left(\mathrm{CN}^{t} \mathrm{Bu}\right) \mathrm{PtAg}\left(\mathrm{PPh}_{3}\right)\right] \mathrm{ClO}_{4} \quad$ (7) and complex $\left[\mathrm{Ag}\left(\mathrm{PPh}_{3}\right)_{2}\right] \mathrm{ClO}_{4}$ co-crystallized.

Figure 5 shows a view of complex 7 and Table 4 lists a selection of relevant bond distances and angles. The structure of the complex cation $\left[\mathrm{Ag}\left(\mathrm{PPh}_{3}\right)_{2}\right]^{+}$found in the same crystal and relevant bond distances and angles for this are presented in Figure S3 of the Supplementary Information.

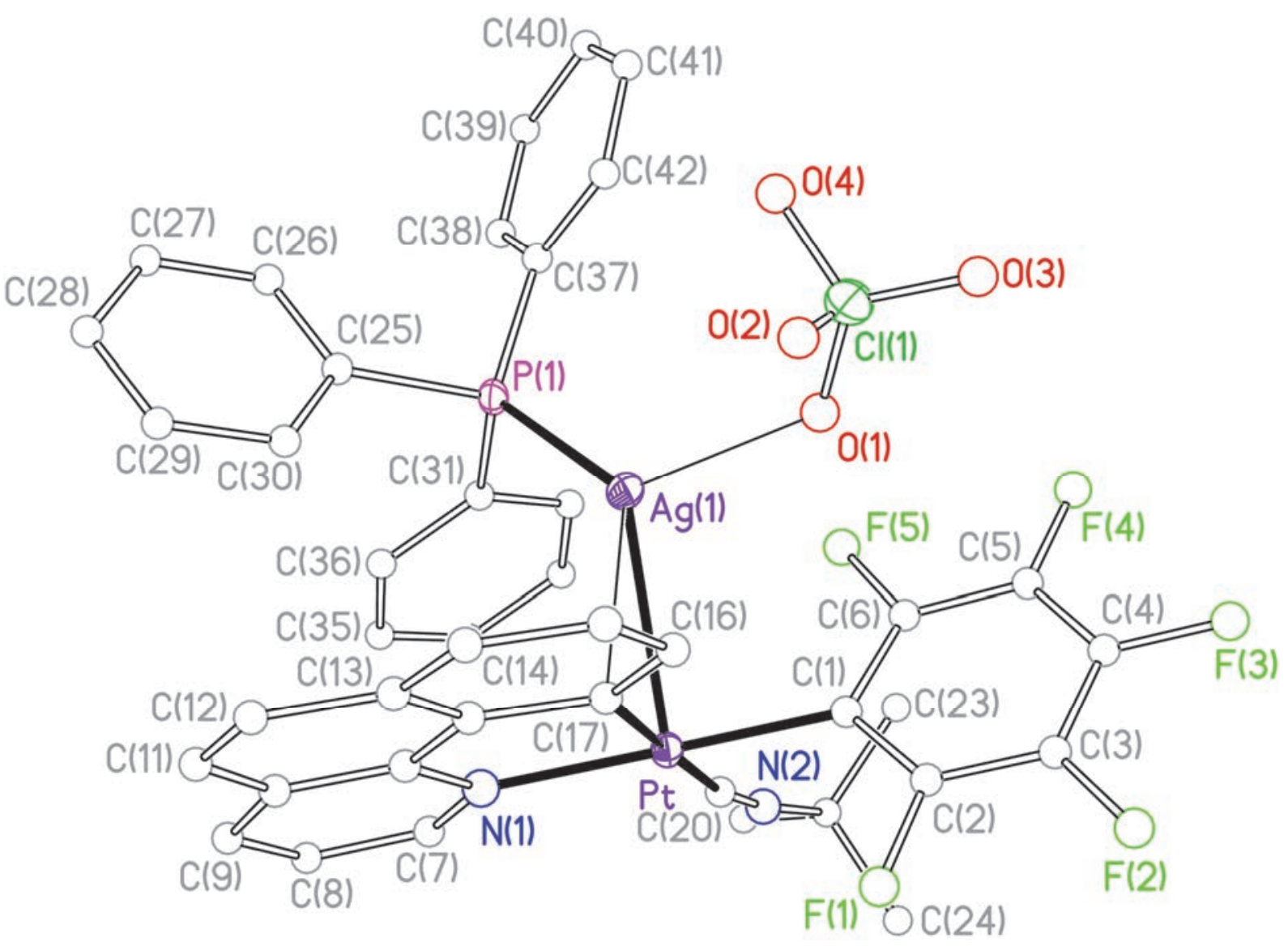

Figure 5. View of the molecular structure of the compound

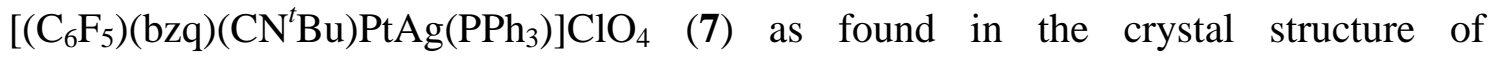
$\left[\left(\mathrm{C}_{6} \mathrm{~F}_{5}\right)(\mathrm{bzq})\left(\mathrm{CN}^{t} \mathrm{Bu}\right) \mathrm{PtAg}\left(\mathrm{PPh}_{3}\right)\right]\left[\mathrm{Ag}\left(\mathrm{PPh}_{3}\right)_{2}\right]\left(\mathrm{ClO}_{4}\right)_{2}$. 
Structure determination of $\mathbf{7}$ confirms its dinuclear nature, with the silver atom linked to the square planar platinum fragment through a Pt-Ag bond and a $\eta^{1}$ interaction with the $\mathrm{C}_{i p s o}$ of the bzq ligand. The Ag center completes its coordination sphere with a $\mathrm{PPh}_{3}$ ligand and a relatively short contact with an oxygen atom of the perchlorate anion (Ag(1)-O(1) 2.381(7) $\AA$ ). The Pt-Ag distance is 2.8939(6) $\AA$, which is somewhat at the higher end of distances found for complexes with a $\mathrm{Pt} \rightarrow \mathrm{Ag}$ bond. 12,13,19,20,26-28,30,49,62-69 This relatively high value of the intermetallic distance can be attributed to the weak coordination of the $\mathrm{ClO}_{4}{ }^{-}$anion to $\mathrm{Ag}$ in a similar way to those observed for the couple of pseudopolymorphs $\mathbf{4 a / b}$ (see above). In this line the Pt-Ag distance in $\mathbf{7}$ is clearly longer that those reported in the similar complexes $\left[\left(\mathrm{C}_{6} \mathrm{X}_{5}\right)_{2}(\mathrm{bzq}) \mathrm{PtAg}\left(\mathrm{PPh}_{3}\right)\right]^{-}(2.728(1)$ $\AA$ for $\mathrm{X}=\mathrm{F}$ and 2.675(3) $\AA$ for $\mathrm{X}=\mathrm{Cl})$ containing the “Ag$\left(\mathrm{PPh}_{3}\right)$ ” fragment too. ${ }^{13}$ The $\eta^{1}$-Ag- $C_{i p s o}$ distance is 2.514(6) $\AA$, which is also at the high end of the values found for these interactions in $\mathbf{4 a} / \mathbf{b}$ and $\mathbf{5}$, or in similar complexes previously reported. ${ }^{13,30}$ As usual, the silver center clearly leans toward the position of the $\mathrm{C}_{i p s o}$ of the bzq ligand, the angle between the Pt-Ag line and the perpendicular of the best Pt square plane being 32.3(1), and the angle between the $A g(1)-C(17)$ line and the perpendicular of the best bzq plane only $17.3(2)^{\circ}$.

Finally, 7 shows intermolecular $\pi \cdots \pi$ interactions of the bzq aromatic ring systems in such a way that the complexes are paired, with interplanar distances of ca. 3.4-3.5 $\AA$.

With respect to the $\left[\mathrm{Ag}\left(\mathrm{PPh}_{3}\right)_{2} \mathrm{ClO}_{4}\right.$ fragment also present in the crystal structure, the most interesting feature is the presence of a $\mathrm{Ag}-\mathrm{OClO}_{3}$ contact (2.677(6) $\AA$ ). As it has been observed before in other structures containing the " $\mathrm{R}_{3} \mathrm{P}-\mathrm{Ag}-\mathrm{PR}_{3}$ " moiety the $\mathrm{P}-\mathrm{Ag}-\mathrm{P}$ sequence of atoms is only linear when there are no other interactions of the silver center ${ }^{78,79}$. In the presence of weak, mainly electrostatic Ag-X interactions ( $\mathrm{X}=$ $\mathrm{F}, \mathrm{O} \ldots$ ) the $\mathrm{P}-\mathrm{Ag}-\mathrm{P}$ angle becomes somewhat narrower than $180^{\circ}{ }^{80-82}$ and, with a formal dative third bond, resulting in a tri-coordinated Ag atom, its environment is nearly planar trigonal. In the case of the $\left[\mathrm{Ag}\left(\mathrm{PPh}_{3}\right)_{2}\right] \mathrm{ClO}_{4}$ fragment found here, the $\mathrm{P}-$ Ag-P angle has a value of $149.29(7)^{\circ}$, a magnitude that seems to indicate that the Ag$\mathrm{OClO}_{3}$ contact has a greater electrostatic component. 
Table 4. Selected bond lengths $(\AA)$ and angles $\left(^{\circ}\right)$ for

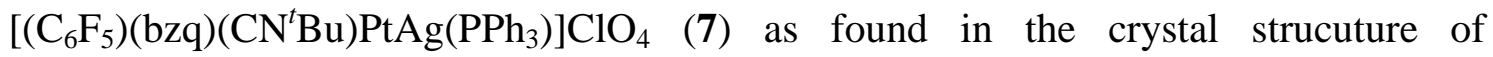
$\left[\left(\mathrm{C}_{6} \mathrm{~F}_{5}\right)(\mathrm{bzq})\left(\mathrm{CN}^{t} \mathrm{Bu}\right) \mathrm{PtAg}\left(\mathrm{PPh}_{3}\right)\right]\left[\mathrm{Ag}\left(\mathrm{PPh}_{3}\right)_{2}\right]\left(\mathrm{ClO}_{4}\right)_{2}$

\begin{tabular}{lrll} 
Pt-C(20) & $1.989(8)$ & $\mathrm{Pt}-\mathrm{C}(1)$ & $2.010(7)$ \\
$\mathrm{Pt}-\mathrm{C}(17)$ & $2.044(7)$ & $\mathrm{Pt}-\mathrm{N}(1)$ & $2.082(6)$ \\
$\mathrm{Pt}-\mathrm{Ag}(1)$ & $2.8939(6)$ & $\mathrm{Ag}(1)-\mathrm{O}(1)$ & $2.381(7)$ \\
$\mathrm{Ag}(1)-\mathrm{P}(1)$ & $2.406(2)$ & $\mathrm{Ag}(1)-\mathrm{C}(17)$ & $2.514(6)$ \\
$\mathrm{P}(1)-\mathrm{Ag}(1)-\mathrm{Pt}$ & $113.95(5)$ & & \\
\hline
\end{tabular}

\subsection{Photophysical properties and Theoretical Calculations}

\subsubsection{Absorption Spectra.}

UV-vis spectra data of compounds 1-9 in solution are summarized in Table S2 (Supplementary Information). As can be seen in Figure 6, in diluted dichloromethane solution $\left(10^{-5} \mathrm{M}\right)$, the mononuclear complexes $\left[\mathrm{Pt}(\mathrm{bzq})\left(\mathrm{C}_{6} \mathrm{~F}_{5}\right)(\mathrm{CNR})\right]\left\{\mathrm{R}={ }^{t} \mathrm{Bu}(\mathbf{1}), 2-\right.$ naphthyl (2), 2,6- $\left.\mathrm{Me}_{2} \mathrm{Ph}(3)\right\}$ exhibit intense $\left(\varepsilon>10^{4} \mathrm{M}^{-1} \mathrm{~cm}^{-1}\right)$ high-energy bands $(\lambda$ range: 250- $350 \mathrm{~nm}$ ) and less intense ( $\varepsilon$ : 1- $2.1 \times 10^{3} \mathrm{M}^{-1} \mathrm{~cm}^{-1}$ ) low-energy (LE) absorptions close to $400 \mathrm{~nm}$. These spectra are quite similar to those revealed by compounds [Pt(bzq)Cl(CNR)] $\left(\mathrm{R}={ }^{t} \mathrm{Bu}\right.$, 2-naphthyl, 2,6-Me $\left.{ }_{2} \mathrm{Ph}\right),{ }^{83}$ trans $\left(\mathrm{C}_{\mathrm{bzq}}, \mathrm{CNR}\right)-$ $[\mathrm{Pt}(\mathrm{bzq})(\mathrm{CN})(\mathrm{CNR})]\left(\mathrm{R}={ }^{t} \mathrm{Bu}, 2\right.$-naphthyl, 2,6-Me $\mathrm{Mh}^{84}$ and $\left[\mathrm{Pt}\left(\mathrm{C}_{6} \mathrm{~F}_{5}\right)(\mathrm{bzq}) \mathrm{L}\right](\mathrm{L}=$ $\mathrm{PPh}_{3}$, tht, NCMe). ${ }^{30}$

According to TD-DFT calculations (see below), the lowest lying absorption has a remarkable spin-allowed intraligand charge transfer [ ${ }^{1}$ ILCT, $\pi-\pi^{*}$ (bzq)] transitions mixed with some metal-to-ligand charge transfer ${ }^{1} \mathrm{MLCT}\left[5 \mathrm{~d}(\mathrm{Pt}) \rightarrow \pi^{*}(\mathrm{bzq})\right]$ in 1 and 3 or a mixed ${ }^{1} \mathrm{ILCT}\left[\pi-\pi^{*}(\mathrm{bzq})\right] /{ }^{1} \operatorname{MLCT}\left[5 \mathrm{~d}(\mathrm{Pt}) \rightarrow \pi^{*}(\mathrm{bzq})\right] /{ }^{1} \mathrm{ML}{ }^{\prime} \mathrm{CT}\left[5 \mathrm{~d}(\mathrm{Pt}) \rightarrow \pi^{*}(\mathrm{CNR})\right]$ character in the CN-2-naphthyl derivative, 2. The slight solvatochromism observed for the absorption bands of complexes 1-3 (UV-vis spectra of 1 recorded in different solvents can be seen in Figure S4) is in agreement with the charge-transfer (CT) nature of the transitions. Diffuse reflectance UV-vis spectra of complexes 1-3 in the solid state exhibit a similar profile to those in solution (see Figure S5, Supplementary Information), hence, the same origin for the absorptions can be presumed. 


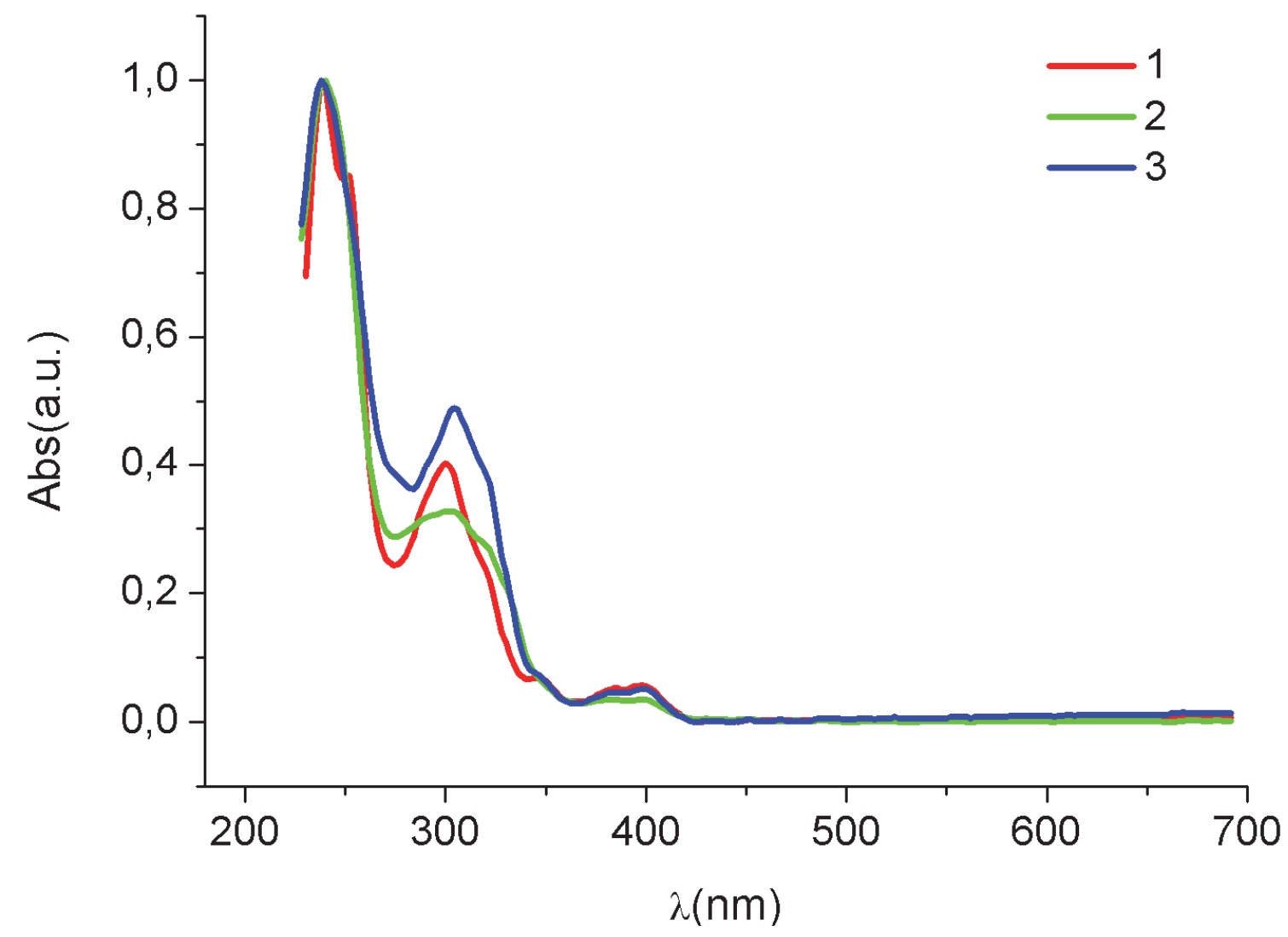

Figure 6. Normalized UV-visible spectra of $\mathbf{1 - 3}$ in $\mathrm{CH}_{2} \mathrm{Cl}_{2}$ solution $\left(10^{-5} \mathrm{M}\right)$ at $298 \mathrm{~K}$.

The slight differences in the lowest energy absorption maxima of these three compounds could be attributed to the $\pi \cdots \pi$ interactions existing in the solid state (Figure S1, Supplementary Information).

The absorption spectra of the heteronuclear complexes (4-9) in $\mathrm{CH}_{2} \mathrm{Cl}_{2}$ are quite similar to those of their corresponding precursors (1-3) both in solution (See Figures S6 for 1, 4 and 7, S7 for 2, 5 and $\mathbf{8}$ and S8 for compounds 3, 6 and 9 in Supplementary Information) and in the solid state (Figure S9 in Supplementary Information). This behavior has been previously observed for compounds $\left(\mathrm{NBu}_{4}\right)\left[\left\{\mathrm{Pt}(\mathrm{bzq})\left(\mathrm{C}_{6} \mathrm{~F}_{5}\right) \mathrm{L}\right\}_{2} \mathrm{Ag}\right]$ $\left(\mathrm{L}=\mathrm{Me}_{2} \mathrm{CO}, \mathrm{PPh}_{3}, \mathrm{pyPh}_{2}\right.$, tht, NCMe). ${ }^{30}$ Only the solid state diffuse reflectance spectrum of compound $\mathbf{6}$ displays a distinctive weak, low-energy feature centered at $\mathbf{4 5 0}$ nm lacking in the mononuclear, dinuclear and trinuclear complexes.

The similarities of the vis-UV spectra of the clusters with those of the mononuclear compounds in solution could be caused by the total or partial breaking of the Pt-Ag bonds in solution. However, in the solid state a different explanation has to be proposed. According to TD-DFT calculations, the formation of the Pt-Ag bonds 
increases the weight of the metallic character (Pt/Ag) in the FOs (see Tables S3 and S4), which leads to the stabilization of both the HOMO and LUMO, but causes little effect in the HOMO-LUMO gap and the transition energy. In complexes 4,5,7-9, the small red shift of the calculated lowest energy absorption with respect to that of the corresponding mononuclear complex seems to be compensated by the lack of the $\pi \cdots \pi$ interaction of the latter. According to TD-DFT calculations, the lowest lying absorption in the dinuclear compounds $\left[\left(\mathrm{C}_{6} \mathrm{~F}_{5}\right)(\mathrm{bzq})(\mathrm{CNR}) \mathrm{PtAg}\left(\mathrm{PPh}_{3}\right)\right] \mathrm{ClO}_{4}\left\{\mathrm{R}={ }^{t} \mathrm{Bu},(7), 2,6-\mathrm{Me}_{2} \mathrm{Ph}\right.$ (9) $\}$ can be ascribed to mixed ${ }^{1} \operatorname{ILCT}\left[\pi-\pi^{*}(\mathrm{bzq})\right] /{ }^{1} \mathrm{MM}{ }^{\prime} \mathrm{LCT}\left[\left(\mathrm{Pt} / \mathrm{AgPPh}_{3}\right) \rightarrow \pi^{*}(\mathrm{bzq})\right]$ transitions, while in compound $\left[\left(\mathrm{C}_{6} \mathrm{~F}_{5}\right)(\mathrm{bzq})(\mathrm{CN}-2-n a p h t h y l) \mathrm{PtAg}\left(\mathrm{PPh}_{3}\right) \mathrm{ClO}_{4}\right.$ (8) an additional ${ }^{1} \mathrm{~L}^{\prime} \mathrm{LCT}\left[\mathrm{CNR} \rightarrow \pi^{*}(\mathrm{bzq})\right]$ contribution can be considered, due to the high contribution of $\mathrm{CN}-2-\mathrm{Np}$ ligand (97\%) to the HOMO. In the trinuclear $\left[\mathrm{Pt}_{2} \mathrm{Ag}\right]$ clusters

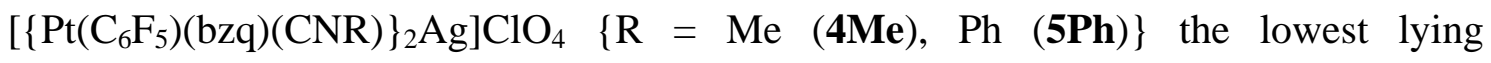
absorption involves the HOMO $\rightarrow$ LUMO (89\%) transition with a mixed ${ }^{1}$ ILCT $\left[\pi-\pi^{*}\right.$ $(\mathrm{bzq})] /{ }^{1} \mathrm{MLM}$ 'CT $[(\mathrm{Pt} / \mathrm{bzq} \rightarrow \mathrm{Ag}]$ character. In the tetranuclear compound $\mathbf{6}$ the presence of stronger Pt-Ag interaction, deduced from the shorter Pt-Ag distance and the smaller deviation of the $\mathrm{Pt}-\mathrm{Ag}$ line from the perpendicular of the best Pt square plane $\left(8.0(1)^{\circ}\right)$, and Ag...Ag contacts, could be the reason for the smaller contribution of the bzq orbitals to the LUMO along with its greater metallic character when compared to the other complexes, causing the red shift of both the calculated and the experimental lowest energy absorptions, which when involving the HOMO $\rightarrow$ LUMO (92.2\%) transition can be ascribed to mixed ${ }^{1} \mathrm{LMM}$ 'CT $\left[(\mathrm{bzq} \rightarrow \mathrm{Pt} / \mathrm{Ag}] /{ }^{1} \mathrm{ILCT}\left[\pi-\pi^{*}(\mathrm{bzq})\right]\right.$ excited states. 


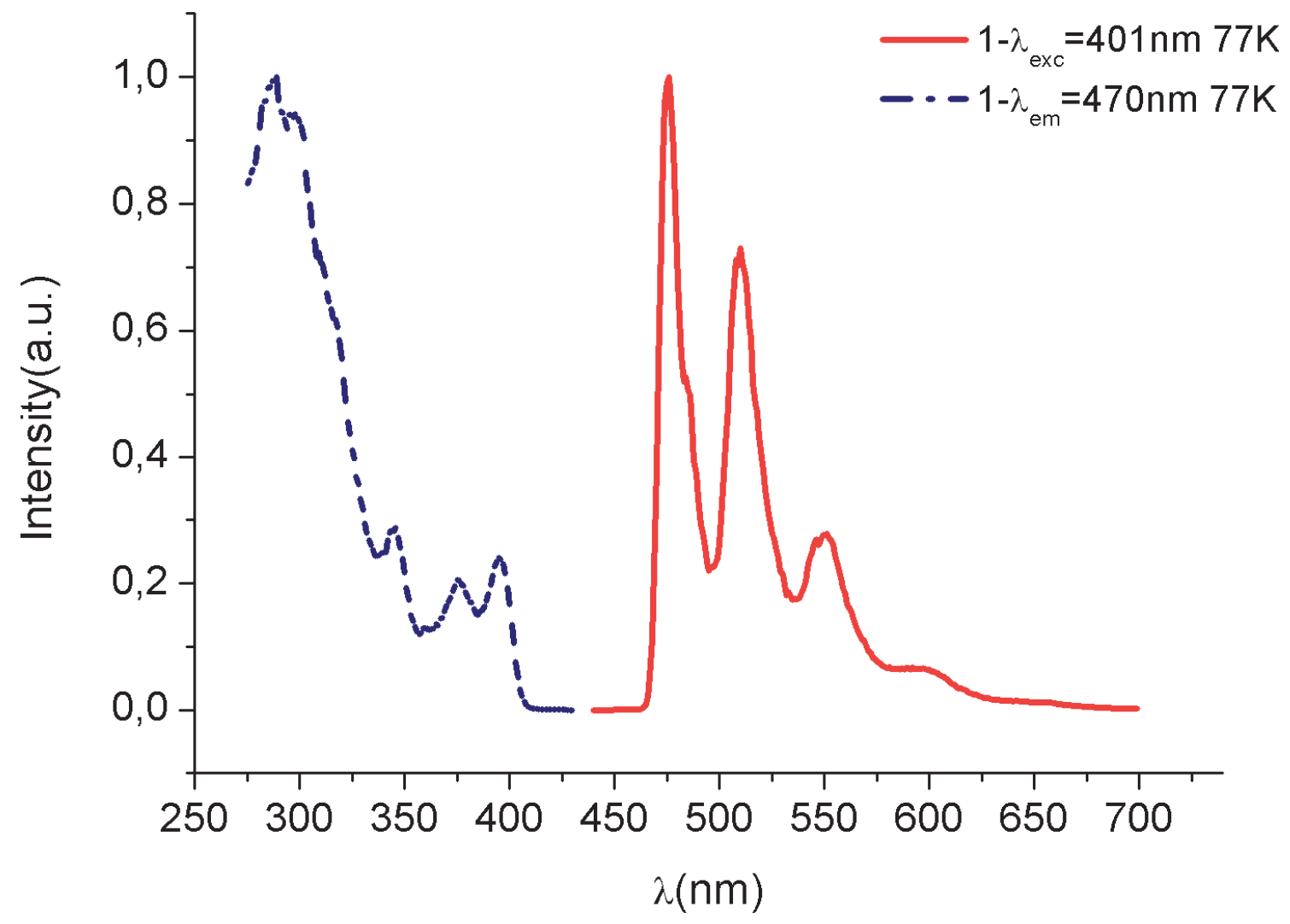

Figure 7. Normalized emission and excitation spectra of $\mathbf{1}$ in 2-Me-THF $\left(10^{-5} \mathrm{M}\right)$.

\subsubsection{Emission spectra.}

All data are summarized in Table 5. Complexes 1-3 are scarcely emissive at room temperature in $\mathrm{CH}_{2} \mathrm{Cl}_{2}$ or 2-Me-THF solution, even at high concentration $\left(10^{-3} \mathrm{M}\right)$, but they show bright phosphorescence at $77 \mathrm{~K}$. The diluted glassy solution of 1-3 in 2-MeTHF (See Figure 7 for compound 1) shows a bluish structured band $\left(\lambda_{\max }=476 \mathrm{~nm}\right.$ ) with vibronic spacing (1370-1500 $\mathrm{cm}^{-1}$ ) typical of the bzq fragment and significantly long lifetimes upon excitation at their lowest energy absorption. For 2, the one with the most conjugated and electron-withdrawing ligand (CN-2-naphthyl), the emission profile is slightly red-shifted and shows additional peaks with respect to $\mathbf{1}$ and $\mathbf{3}$. The phosphorescent emission of these mononuclear complexes, whose excitation spectrum resembles the absorption one, can be assigned therefore to the ${ }^{3} \mathrm{ILCT}$ emissive state on the bzq ligand mixed with little ${ }^{3} \mathrm{MLCT}$ character and some ${ }^{3} \mathrm{ML}$ 'CT character in the CN-2-naphthyl derivative, 2. 
Table 5.-Photophysical data for compounds 1-9

\begin{tabular}{|c|c|c|c|c|}
\hline Compound & & $\lambda_{\text {exc }} / \mathbf{n m}$ & $\lambda_{\mathrm{em}}(\mathrm{nm})[\Phi]$ & $\tau / \mu s$ \\
\hline \multirow{3}{*}{1} & Solid (298K) & 375 & $\begin{array}{c}488_{\max }, 522,557, \\
610_{\text {sh }} \text { tail to } 750\end{array}$ & $26.0(488)$ \\
\hline & Solid (77K) & 394 & $\begin{array}{c}\text { 486, 507, } 523_{\max } \\
\text { 550, } 592 \text { tail to } \\
750\end{array}$ & $\begin{array}{c}107.7(74.8 \%), 665.6(25.2 \%) \\
(523), \\
165.4(82.0 \%), 893.5(18.0 \%) \\
(550)\end{array}$ \\
\hline & $\begin{array}{c}\text { 2-Me-THF } \\
10^{-5} \mathrm{M}(77 \mathrm{~K})\end{array}$ & 401 & $\begin{array}{c}476_{\max }, 484_{\mathrm{sh}}, \\
510,551,597 \text { tail } \\
\text { to } 680\end{array}$ & $711.0(476)$ \\
\hline \multirow{2}{*}{2} & Solid (77K) & 380 & $\begin{array}{c}510_{\max }, 551,599 \\
\text { tail to } 670\end{array}$ & \begin{tabular}{|c|}
$302.6(510)$, \\
$303.6(62.6 \%), 13.2(37.4 \%)$ \\
$(551)$, \\
$304.9(599)$ \\
\end{tabular} \\
\hline & $\begin{array}{c}\text { 2-Me-THF } \\
10^{-5} \mathrm{M}(77 \mathrm{~K})\end{array}$ & 401 & $\begin{array}{c}485_{\max }, 497,521, \\
537,561,612 \text { tail } \\
\text { to } 720\end{array}$ & $\begin{array}{c}666.5(62.3 \%), \\
2965.5(37.7 \%)(485), \\
801.5(69.1 \%), \\
3737.6(30.9 \%)(521)\end{array}$ \\
\hline \multirow{4}{*}{3} & Solid (77K) & 390 & $\begin{array}{l}483,513_{\max }, 552, \\
592,604,630 \text { tail } \\
\text { to } 730\end{array}$ & $\begin{array}{c}\text { 78.6(77.0\%), } 572.0(23.0 \%) \\
\text { (513), } \\
95.4(77.2 \%), 825.6(22.8 \%) \\
(552)\end{array}$ \\
\hline & $\begin{array}{c}\text { 2-Me-THF } \\
10^{-5} \mathrm{M}(77 \mathrm{~K})\end{array}$ & 401 & $\begin{array}{c}475_{\max }, 483_{\mathrm{sh}}, \\
509,548,595 \text { tail } \\
\text { to } 700\end{array}$ & $579.1(475)$ \\
\hline & $\begin{array}{c}\mathrm{CH}_{2} \mathrm{Cl}_{2} 10^{-5} \mathrm{M} \\
(77 \mathrm{~K})\end{array}$ & 400 & $\begin{array}{l}491_{\max }, 527,562 \\
\text { tail to } 675\end{array}$ & $\begin{array}{c}\text { 282.8(70.1\%), } \\
\text { 1018.0(29.9\%) (491), } \\
\text { 234.7(67.4\%), } \\
1108.7(32.6 \%)(527)\end{array}$ \\
\hline & $\begin{array}{c}\mathrm{CH}_{2} \mathrm{Cl}_{2} 10^{-3} \mathrm{M} \\
(77 \mathrm{~K})\end{array}$ & 318 & $\begin{array}{c}493_{\max }, 530,564 \\
\text { tail to } 600\end{array}$ & \\
\hline \multirow[t]{2}{*}{4} & Solid (77K) & 397 & $\begin{array}{c}496_{\max }, 507_{\mathrm{sh}}, \\
533,573 \text { tail to } \\
730 \\
\end{array}$ & $\begin{array}{c}21.4 \text { (84.5\%), 83.5(15.5\%) } \\
\text { (496) }\end{array}$ \\
\hline & $\begin{array}{c}\text { 2-Me-THF } \\
10^{-5} \mathrm{M}(77 \mathrm{~K})\end{array}$ & 398 & $\begin{array}{c}474_{\max }, 509,548, \\
593 \text { tail to } 700\end{array}$ & 626.7 (474) \\
\hline \multirow{2}{*}{5} & Solid (77K) & 395 & $\begin{array}{l}522_{\max }, 532_{\text {sh }} \\
563,607 \text { tail to } \\
700\end{array}$ & $\begin{array}{c}87.4(62.5 \%), 217(37.5 \%) \\
\text { (522) } \\
64.9(44.3 \%), 229.9(55.7 \%) \\
(563)\end{array}$ \\
\hline & $\begin{array}{c}\text { 2-Me-THF } \\
10^{-5} \mathrm{M}(77 \mathrm{~K})\end{array}$ & 383 & $\begin{array}{l}486_{\mathrm{max}}, 491_{\mathrm{sh}} \\
\text { 523, } 536_{\mathrm{sh}}, 564 \\
611 \text { tail to } 750\end{array}$ & $\begin{array}{c}\text { 454.9(62.1\%), } \\
1761.2(37.9 \%)(486), \\
490.0(67.8 \%), \\
2364.6(32.2 \%)(523)\end{array}$ \\
\hline
\end{tabular}




\begin{tabular}{|c|c|c|c|c|}
\hline \multirow{4}{*}{6} & Solid (298K) & 393 & $\begin{array}{c}575 \text { tail to } 800 \\
{[0.251]}\end{array}$ & $16.4(574)$ \\
\hline & Solid (77K) & 393 & $\begin{array}{c}567_{\max }, 603 \text { tail to } \\
760 \\
\end{array}$ & 25.2 (567) \\
\hline & $\begin{array}{c}\text { 2-Me-THF } \\
2.510^{-6} \mathrm{M}(77 \mathrm{~K}) \\
\end{array}$ & 398 & \begin{tabular}{|c}
$474_{\max }, 508,547$, \\
593 tail to 680 \\
\end{tabular} & $576.3(474)$ \\
\hline & $\begin{array}{c}\mathrm{CH}_{2} \mathrm{Cl}_{2} 10^{-5} \mathrm{M} \\
(77 \mathrm{~K})\end{array}$ & 400 & $\begin{array}{c}490_{\max }, 527,565 \\
606 \text { tail to } 660\end{array}$ & $\begin{array}{c}670.2(52.3 \%), 104.1(47.7 \%) \\
(490), \\
704.9(50.5 \%), 141.8(49.5 \%) \\
(527)\end{array}$ \\
\hline \multirow{3}{*}{7} & Solid (298K) & 392 & $\begin{array}{c}500,526_{\max } \text { tail to } \\
750[0.087]\end{array}$ & $29.0(526)$ \\
\hline & Solid (77K) & 400 & $\begin{array}{l}491,548_{\max }, 567 \\
\text { tail to } 750\end{array}$ & $\begin{array}{c}\text { 57.4(93.1\%), 356.6(6.9\%) } \\
\text { (491), } \\
48.5(90.7 \%), 437.2(9.3 \%) \\
(548) \\
\end{array}$ \\
\hline & $\begin{array}{c}\text { 2-Me-THF } \\
10^{-5} \mathrm{M}(77 \mathrm{~K})\end{array}$ & 398 & $\begin{array}{c}475_{\max }, 509,548 \\
593 \text { tail to } 700\end{array}$ & $654.9(477)$ \\
\hline \multirow[t]{2}{*}{8} & Solid (77K) & 410 & $\begin{array}{c}521_{\max }, 564,610 \\
660_{\text {sh }} \text { tailto } 750\end{array}$ & $\begin{array}{c}339.7(69.8 \%), 36.2(30.2 \%) \\
\text { (521), } \\
237.1(84.6 \%), 748.2(15.4 \%) \\
(564)\end{array}$ \\
\hline & $\begin{array}{l}\text { 2-Me-THF } \\
10^{-5} \mathrm{M}(77 \mathrm{~K})\end{array}$ & 398 & $\begin{array}{c}485_{\max }, 496,522 \\
536_{\mathrm{sh}}, 562,610 \\
\text { tail to } 750\end{array}$ & $\begin{array}{c}\text { 791.4(75.0\%), } \\
3553.1(25.0 \%)(485)\end{array}$ \\
\hline \multirow{4}{*}{9} & Solid (298K) & 394 & $\begin{array}{l}490,513_{\max }, 544 \\
\text { tail to } 750[0.113]\end{array}$ & $\begin{array}{l}15.9(490), \\
16.0(513), \\
14.3(544)\end{array}$ \\
\hline & Solid (77K) & 400 & $\begin{array}{c}494,544_{\max } \text { tail to } \\
750\end{array}$ & $\begin{array}{c}62.3(83.6 \%), 413.6(16.4 \%) \\
\text { (494), } \\
49.3(84.9 \%), 385.1(15.1 \%) \\
(544)\end{array}$ \\
\hline & $\begin{array}{c}\text { 2-Me-THF } \\
10^{-5} \mathrm{M}(77 \mathrm{~K})\end{array}$ & 398 & $\begin{array}{c}474_{\max }, 508,547 \\
591 \text { tail to } 700\end{array}$ & 609.5 (474) \\
\hline & $\begin{array}{c}\mathrm{CH}_{2} \mathrm{Cl}_{2} 10^{-5} \mathrm{M} \\
(77 \mathrm{~K})\end{array}$ & 400 & $\begin{array}{l}487_{\max }, 522,557 \\
600_{\text {sh }} \text { tail to } 700\end{array}$ & $\begin{array}{c}100.6(63.2 \%), 480.9(36.8 \%) \\
(487), \\
82.6(65.3 \%), 476.7(34.7 \%) \\
(522)\end{array}$ \\
\hline
\end{tabular}

This behavior is similar to that observed for compounds [Pt(bzq)Cl(CNR)] $(\mathrm{R}=$ ${ }^{t} \mathrm{Bu}, 2$-naphthyl, 2,6- $\left.\mathrm{Me}_{2} \mathrm{Ph}\right)^{83}$ which was explained by the greater contribution of the $\mathrm{CN}-2-\mathrm{Np}$ ligand to the excited state compared to $\mathrm{CN}-{ }^{t} \mathrm{Bu}$ and $\mathrm{CN}-\mathrm{Me}_{2} \mathrm{Ph}$. In a $\mathrm{CH}_{2} \mathrm{Cl}_{2}$ rigid matrix (77K) compounds $\mathbf{1 - 3}$ show similar phosphorescent emission to those in THF both in diluted $\left(10^{-5} \mathrm{M}\right)$ and in more concentrated $\left(10^{-3} \mathrm{M}\right)$ solutions (for complex 
3 see Figure S10 in Supplementary Information), indicating that in $\mathrm{CH}_{2} \mathrm{Cl}_{2}$ in the range $10^{-5} \mathrm{M}-10^{-3} \mathrm{M}$ the emission also comes from excited states of the monomer species.

Heteronuclear compounds 4-9 are not good emitters in solution at 298K, however they are at $77 \mathrm{~K}$. In glassy 2-Me-THF solution at any concentration $\left(10^{-3} \mathrm{M}, 10^{-4} \mathrm{M}, 10^{-5}\right.$ M) they show the same emission spectra as their corresponding starting complexes 1-3 (see Table 5).

In a less coordinating solvent such as $\mathrm{CH}_{2} \mathrm{Cl}_{2}$ at $77 \mathrm{~K}$ the emission spectra of complexes 3, 6, 9 (see Figure S11 in Supplementary Information) gave analogous results to those in 2-Me-THF. Bearing in mind the ${ }^{31} \mathrm{P}$ NMR experiments, and the absorption spectra, the cleavage of the Pt-Ag bonds seems to justify the negligible effect of the Ag centers on the emission of compounds 4-9 in glassy 2-Me-THF or rigid matrix of $\mathrm{CH}_{2} \mathrm{Cl}_{2}$, which seems to arise from excited states originated in the “Pt(bzq) $\left(\mathrm{C}_{6} \mathrm{~F}_{5}\right)(\mathrm{CNR})$ ” ( $\mathrm{R}={ }^{t} \mathrm{Bu}$, 2-naphthyl, 2,6-Me $\left.{ }_{2} \mathrm{Ph}\right)$ fragment, mainly ${ }^{3} \mathrm{IL}$ in nature with little ${ }^{3} \mathrm{MLCT}$ (and ${ }^{3} \mathrm{ML}$ 'CT for $\mathbf{5}$ and 8 ) contribution.

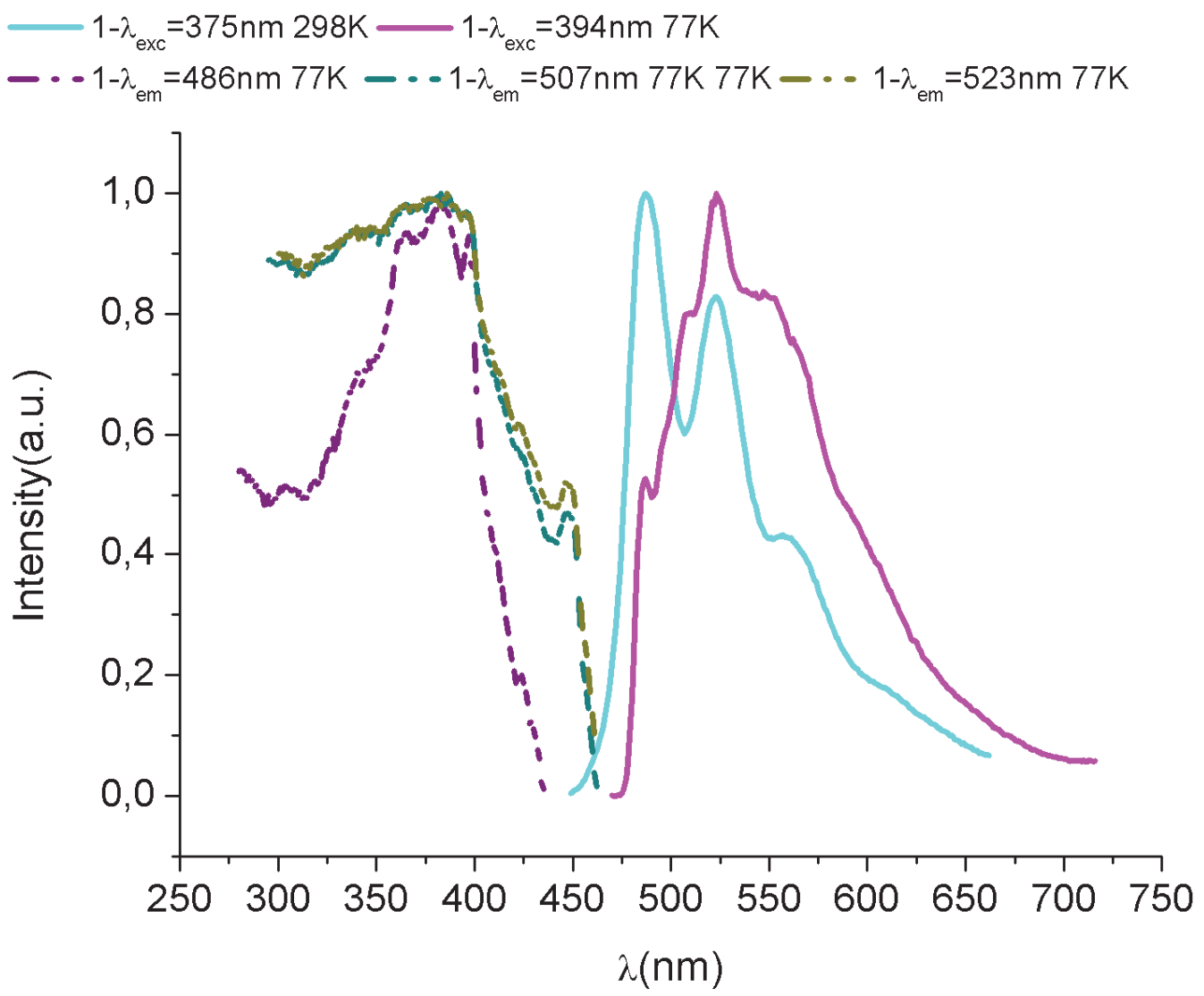

Figure 8. Normalized emission and excitation spectra of $\mathbf{1}$ in the solid state at $298 \mathrm{~K}$ and $77 \mathrm{~K}$. 
In the solid state, the mononuclear compounds 1-3 are moderately emissive at $77 \mathrm{~K}$ and only $\mathbf{1}$ emits at 298K. At room temperature the emission band of $\mathbf{1}$ (Figure 8) is quite similar to that observed in glassy 2-Me-THF $\left(10^{-5} \mathrm{M}\right)$ and can be assigned mainly to a ${ }^{3} \mathrm{IL}$ excited state. At low temperature, the emission profile changes and its maximum appears clearly red-shifted. The excitation spectra monitored at the low energy peaks $(507,523,550 \mathrm{~nm})$ are comparable to those observed for other benzoquinolinate complexes of $\mathrm{Pt}(\mathrm{II})$ exhibiting $\pi \cdots \pi$ stacking interactions in rigid media. ${ }^{21,47,83,84}$ On the basis of the extended assembly observed in the crystal structure of complex 1 it seems reasonable to consider that the emission at $77 \mathrm{~K}$ arise from excited states corresponding to aggregates formed as a consequence of $\pi$ - $\pi$ interactions between bzq groups of adjacent molecules with some contribution of ${ }^{3} \pi \pi^{*}$ excimeric emission.

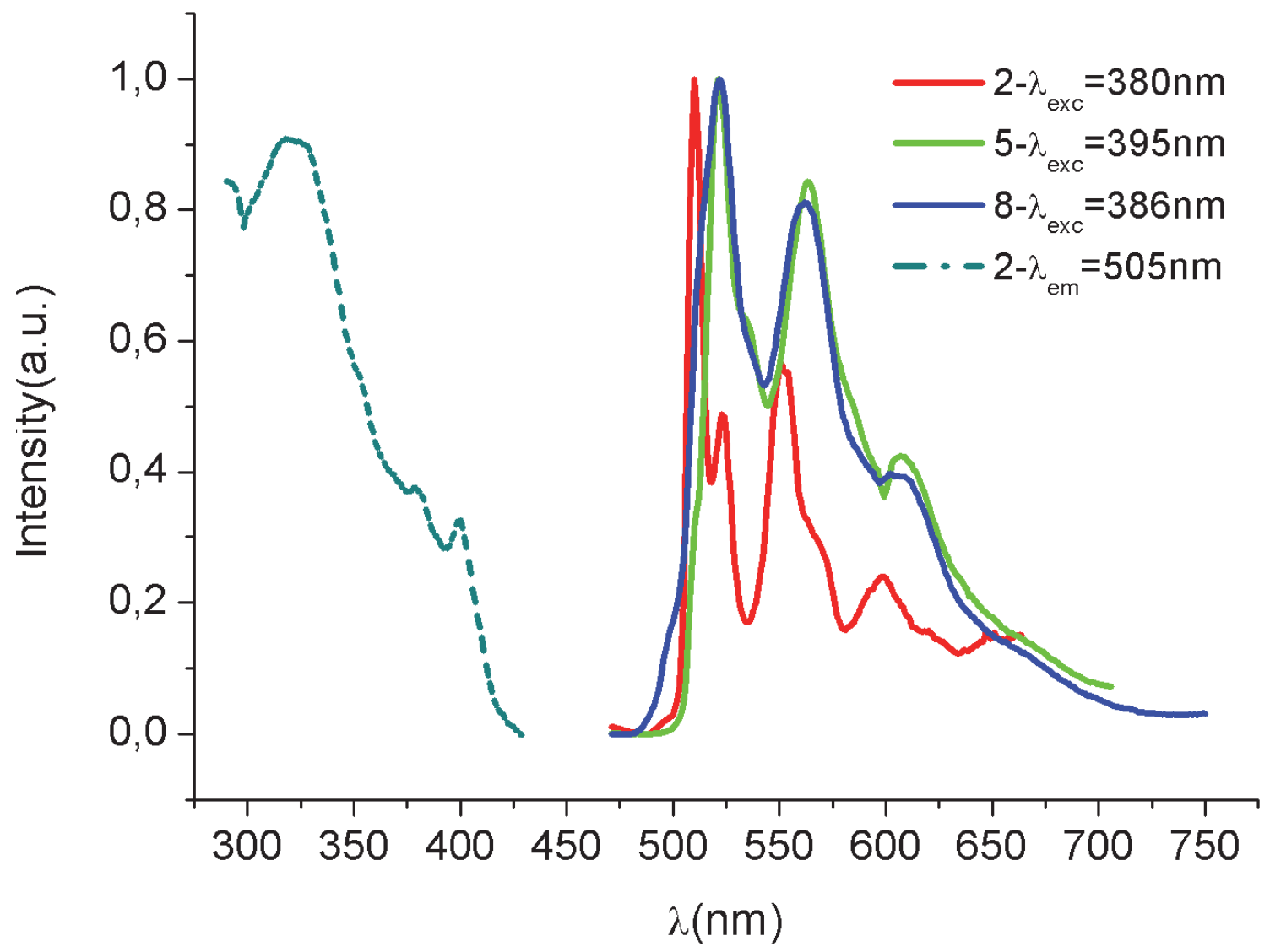

Figure 9. Normalized emission spectra of 2, 5, 8 and excitation spectrum of 2 in the solid state at $77 \mathrm{~K}$. 
The emission and excitation spectra of 3 at 77K (Figure S12, Supplementary Information) are quite similar to those of $\mathbf{1}$ and the same origin of the emission can be presumed. However the emission of compound 2 (Figure 9) is a greenish structured band $\left(\lambda_{\max }=510 \mathrm{~nm}\right)$ arising from an excited state of the monomer species since the excitation spectra fit well with the absorption spectra at 298K both in the solid state and in $\mathrm{CH}_{2} \mathrm{Cl}_{2}$ solution. Therefore, the emission is mainly ${ }^{3} \mathrm{IL}$ in nature with some ${ }^{3} \mathrm{MLCT} /{ }^{3} \mathrm{ML}$ 'CT character.

The Pt/Ag compounds containing CN-2-Np, $\quad\left[\left\{\mathrm{Pt}\left(\mathrm{C}_{6} \mathrm{~F}_{5}\right)(\mathrm{bzq})(\mathrm{CN}-2-\right.\right.$ naphthyl) $\left.\}_{2} \mathrm{Ag}\right] \mathrm{ClO}_{4}(5)$ and $\left[\mathrm{Pt}\left(\mathrm{C}_{6} \mathrm{~F}_{5}\right)(\mathrm{bzq})\left(\mathrm{CN}-2\right.\right.$-naphthyl)Ag $\left.\mathrm{PPh}_{3}\right] \mathrm{ClO}_{4}$ (8), are only moderately emissive in the solid state at 77K (see Figure 9) and show a greenish phosphorescent emission quite similar to that of the starting complex $\left[\mathrm{Pt}\left(\mathrm{C}_{6} \mathrm{~F}_{5}\right)(\mathrm{bzq})(\mathrm{CN}-2-\mathrm{Np})\right](2)$, which is mainly ${ }^{3} \mathrm{ILCT}$ in nature.

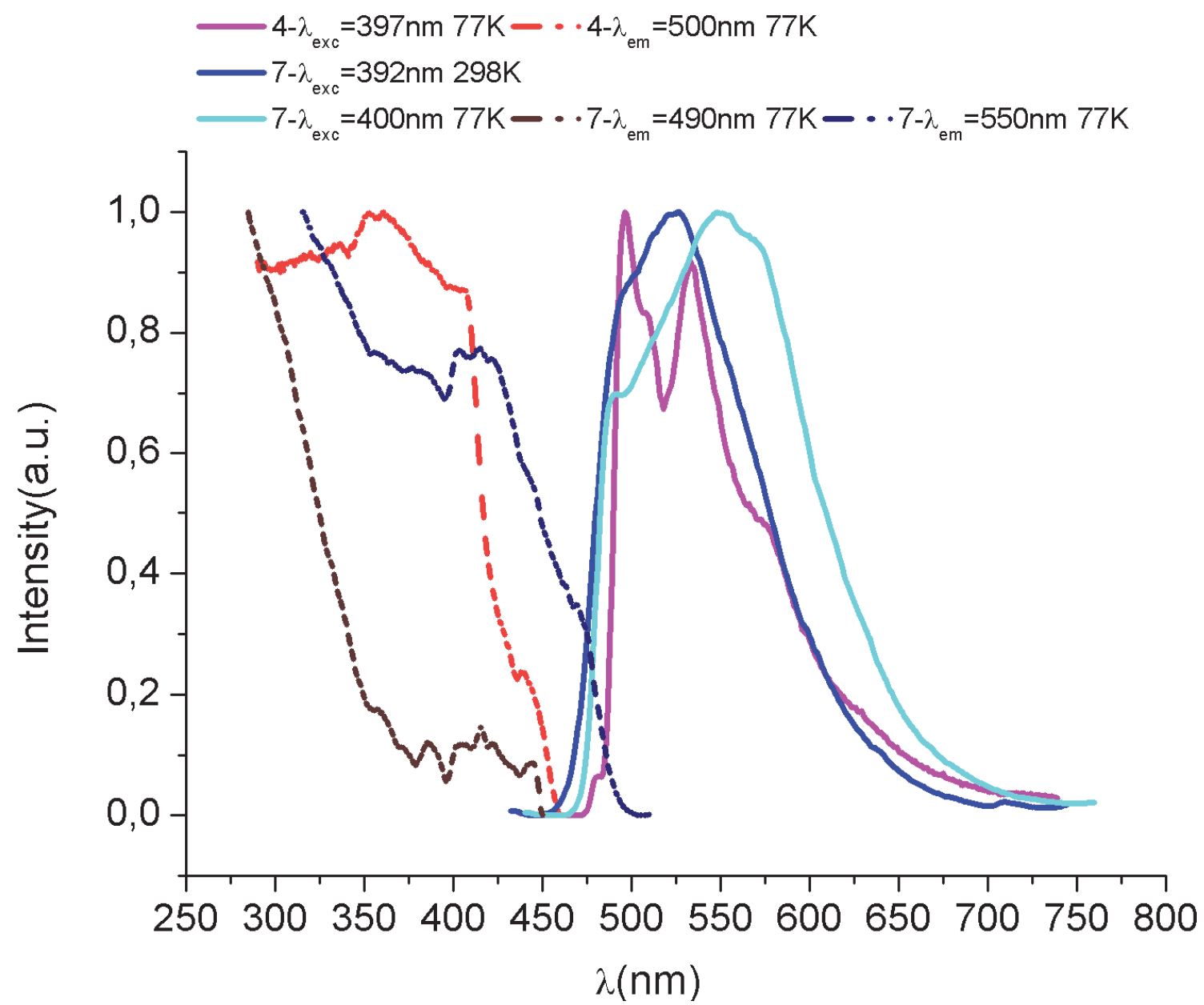

Figure 10. Normalized emission and excitation spectra of $\mathbf{4}$ and $\mathbf{7}$ in the solid state at $77 \mathrm{~K}$. 
The presence of Pt-Ag bonds seem to cause a negligible effect in the energy of the excited state of $\mathbf{5}$ and $\mathbf{8}$ with respect to the mononuclear complex, 2, but an appreciable reduction of their emission lifetime.

Similarly, the trinuclear compound $\left[\left\{\mathrm{Pt}\left(\mathrm{C}_{6} \mathrm{~F}_{5}\right)(\mathrm{bzq})\left(\mathrm{CN}{ }^{-} \mathrm{Bu}\right)\right\}_{2} \mathrm{Ag}^{-} \mathrm{ClO}_{4}\right.$ (4) shows a weak phosphorescent emission in the solid state at 77K (see Figure 10) with the same profile and energy peaks as the emission in 2-Me-THF that can be attributed to a ${ }^{3}$ ILCT excited state with some ${ }^{3}$ MLM'CT character.

Unlike 8, the dinuclear compounds $\left[\mathrm{Pt}\left(\mathrm{C}_{6} \mathrm{~F}_{5}\right)(\mathrm{bzq})\left(\mathrm{CN}-{ }^{t} \mathrm{Bu}\right) \mathrm{AgPPh}_{3}\right] \mathrm{ClO}_{4}(7)$ and $\left[\mathrm{Pt}\left(\mathrm{C}_{6} \mathrm{~F}_{5}\right)(\mathrm{bzq})\left(\mathrm{CN}-2,6-\mathrm{Me}_{2} \mathrm{Ph}\right) \mathrm{AgPPh}_{3}\right] \mathrm{ClO}_{4}(\mathbf{9})$ are emissive at $298 \mathrm{~K}$ showing a green phosphorescence (see Figures 10 and 11 ) with moderate quantum yield ( $\Phi=8.7 \% 7$, 11.3\% 9). In both cases, the broad emission band clearly resolves into two bands at 77K: a high energy (HE) band with maximum at $~ 490 \mathrm{~nm}$, and a more intense low energy (LE) one with maxima at $\lambda_{\max }=548 \mathrm{~nm}$ (7), $544 \mathrm{~nm}$ (9) clearly red-shifted with respect to those at $298 \mathrm{~K}$. This behavior resembles that observed for the analogous complex $\left[\mathrm{Pt}\left(\mathrm{C}_{6} \mathrm{~F}_{5}\right)(\mathrm{bzq})\left(\mathrm{PPh}_{3}\right) \mathrm{Ag}\left(\mathrm{pyPh}_{2}\right)\right] \mathrm{ClO}_{4}{ }^{30}$ in which the $\mathrm{HE}$ band was ascribed to mixed ${ }^{3} \operatorname{ILCT}\left(\pi-\pi^{*}(\mathrm{bzq})\right) /{ }^{3} \mathrm{MLCT}\left(5 \mathrm{~d}(\mathrm{Pt}) \rightarrow \pi^{*}(\mathrm{bzq})\right)$, as in the mononuclear precursor. The LE emission can be ascribed to a mixed ${ }^{3} \mathrm{ILCT}\left(\pi-\pi^{*}\right.$ (bzq)) $/{ }^{3} \mathrm{MM}^{\prime} \mathrm{LCT}\left(\mathrm{Pt} / \mathrm{AgPPh}_{3}\right.$ $\rightarrow$ bzq) transition, showing that the contribution of $\mathrm{AgPPh}_{3}$ orbitals to $\mathrm{HOMO}$ changes the nature of the lowest energy emissive state.

The tetranuclear complex $\left[\left\{\mathrm{Pt}\left(\mathrm{C}_{6} \mathrm{~F}_{5}\right)(\mathrm{bzq})\left(\mathrm{CN}-2,6-\mathrm{Me}_{2} \mathrm{Phl}\right) \mathrm{Ag}\right\}_{2}\right]\left(\mathrm{ClO}_{4}\right)_{2}$ shows bright yellowish phosphorescence (Figure 11) at $298 \mathrm{~K}$ and 77K. Excitation at $390 \mathrm{~nm}$ of a powdered sample of $\mathbf{6}$ at room temperature leads to an intense structureless emission band, with its maximum at $\lambda_{\max }=575 \mathrm{~nm}(\Phi=25.1 \%, \tau=16.4 \mu \mathrm{s})$ that appears with a structured profile upon cooling to $77 \mathrm{~K}$.

This emission, as in the case of the lower energy absorption, is clearly red-shifted with respect to those of all the other Pt/Ag compounds (see Table 5 and Figure 11), and can be assigned according to TD-DFT calculations to a mixed ${ }^{3} \mathrm{LMM}^{\prime} \mathrm{CT}[(\mathrm{bzq}) \rightarrow$ $\mathrm{Pt} / \mathrm{Ag}] /{ }^{3} \mathrm{ILCT} \quad\left[\pi-\pi^{*} \quad(\mathrm{bzq})\right]$ transition. In the tetranuclear compound $\left[\left\{\mathrm{Pt}(\mathrm{bzq})\left(\mathrm{C}_{6} \mathrm{~F}_{5}\right)\left(\mathrm{CN}-2,6-\mathrm{Me}_{2} \mathrm{Ph}\right) \mathrm{Ag}\right\}_{2}\right](6)$ the presence of a $\mathrm{Pt}_{2} \mathrm{Ag}_{2}$ core with $\mathrm{Pt} \cdots \mathrm{Ag}$ and Ag...Ag contacts increases the metallic character of the LUMO compared to other benzoquinolinate complexes, leading to a lower energy and even more efficient excited state. The yellowish phosphorescence of $\mathbf{6}$ has some similarities with the yellowish 
emissions found for $\left[\mathrm{Pt}_{2} \mathrm{Ag}_{4}(\mathrm{C} \equiv \mathrm{CPh})_{8}\right](545 \mathrm{~nm}, 298 \mathrm{~K})^{85,86}$ and $\left[\mathrm{Pt}_{2} \mathrm{M}_{4}\{\mathrm{C} \equiv \mathrm{C}(3-\right.$ $\left.\mathrm{OMe}) \mathrm{C}_{6} \mathrm{H}_{4}\right\}_{8}$ ] (550 nm, $\left.298 \mathrm{~K}\right),{ }^{87}$ where their emission was assigned to emissive states derived from a ${ }^{3} \mathrm{MLM}{ }^{\prime} \mathrm{CT}\left[\mathrm{Pt}(\mathrm{d}) / \pi(\mathrm{C} \equiv \mathrm{CR}) \rightarrow \mathrm{Pt}(\mathrm{pz}) / \mathrm{Ag}(\mathrm{sp}) / \pi^{*}(\mathrm{C} \equiv \mathrm{CR})\right]$ state modified

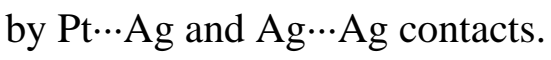

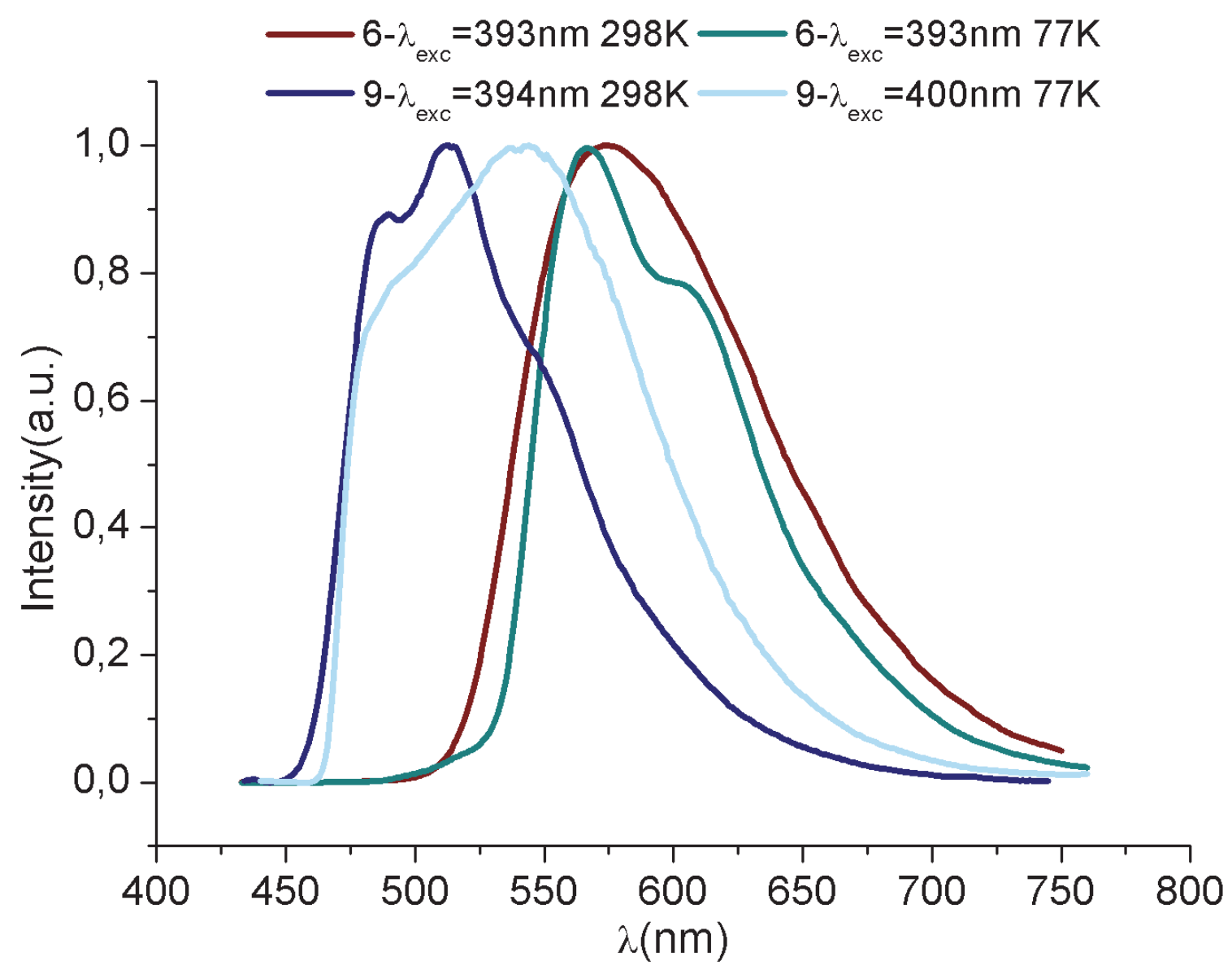

Figure 11. Normalized emission spectra of $\mathbf{6}$ and $\mathbf{9}$ in the solid state at $298 \mathrm{~K}$ and $77 \mathrm{~K}$.

\subsubsection{Theoretical Calculations}

To better explain the nature of the lower-energy transitions of complexes 1-9, time-dependent density functional theory (TD-DFT) calculations were carried out using the M06 functionals. The isonitrile ligands have been modeled as CNMe in the case of $\mathbf{4}$ (4Me) and as $\mathrm{CNPh}$ in the case of 5 and $\mathbf{6}(\mathbf{5 P h}, \mathbf{6 P h})$ in order to simplify the calculations. The geometric parameters of the optimized $\mathrm{S}_{0}$ structures, the frontier MOs plots involved in the calculated electronic transitions, their population analysis (\%), and the calculated lower-energy electronic transitions can be seen in Figures S13-S30 and 
Tables S3-S5 and agree well with the experimental values. In the mononuclear complexes 1-3, the highest occupied molecular orbital (HOMO) is mostly constructed from orbitals located on the bzq $(\sim 78 \%)$ and the platinum center $(\sim 17 \%)$. Insignificant contributions of $\mathrm{C}_{6} \mathrm{~F}_{5}(1 \%)$ and $\mathrm{CNR}(4 \%)$ are observed. The lower unoccupied molecular orbital (LUMO) is well located on the $\mathrm{N}$ ring of the bzq (92\% 1, 81\% 2, 91\% 3), and to a lesser extent on Pt (3\%) and CNR (2\% 1, 13\% 2, 3\% 3), orbitals. In these complexes the contribution of the $\mathrm{Ar}_{\mathrm{f}}$ orbitals to the frontier orbitals (FOs) is insignificant, as also occurred in the analogous complexes $\left[\mathrm{Pt}\left(\mathrm{C}_{6} \mathrm{~F}_{5}\right)(\mathrm{bzq}) \mathrm{L}\right]\left(\mathrm{L}=\mathrm{PPh}_{3}\right.$, tht, NCMe). ${ }^{30}$ The calculated electronic transition in $\mathrm{CH}_{2} \mathrm{Cl}_{2}$ fits well, within the accuracy of the method, with the experimental absorptions. Calculations indicate that the major contribution to the lowest lying absorption involves the HOMO $\rightarrow$ LUMO ( 93\%) transition, with a remarkable spin-allowed intraligand charge transfer [ ${ }^{1}$ ILCT, $\pi-\pi^{*}$ (bzq)] transitions mixed with little metal-to-ligand charge transfer ${ }^{1}$ MLCT $\left[5 \mathrm{~d}(\mathrm{Pt}) \rightarrow \pi^{*}(\mathrm{bzq})\right]$. Little ${ }^{1} \mathrm{ML}{ }^{\prime} \mathrm{CT} \quad\left[5 \mathrm{~d}(\mathrm{Pt}) \rightarrow \pi^{*}(\mathrm{CNR})\right]$ character in the CN-2-Np derivative, 2 is also observed. The higher-energy bands, in the range of 300-350 nm, have a larger ${ }^{1}$ MLCT character with some ${ }^{1} \mathrm{~L}$ 'LCT $\left(\mathrm{Ar}_{\mathrm{f}} \rightarrow \mathrm{bzq}\right)$, due to the higher contribution of the $\mathrm{Ar}_{\mathrm{f}}$ orbitals to $\mathrm{H}-1$ or $\mathrm{H}-2$.

In the dinuclear compounds $\left[\left(\mathrm{C}_{6} \mathrm{~F}_{5}\right)(\mathrm{bzq})(\mathrm{CNR}) \mathrm{PtAg}\left(\mathrm{PPh}_{3}\right)\right] \mathrm{ClO}_{4}\left\{\mathrm{R}={ }^{t} \mathrm{Bu}\right.$, (7), 2,6- $\mathrm{Me}_{2} \mathrm{Ph}(9)$, the HOMO is constructed from orbitals located on the bzq ( 45\%), the platinum center ( 13\%) and $\mathrm{M}$ ' fragment $\left(\mathrm{AgPPh}_{3}, \sim 37 \%\right)$ with small contributions of CNR (10\%) in compound 9. The LUMO is not much different from the HOMO; showing a slightly higher contribution of the $\mathrm{N}$ ring of the bzq orbitals along with a lower contribution of those of the $\mathrm{M}^{\prime}$ fragment. As the major contribution to the lowest lying absorption involves the HOMO $\rightarrow$ LUMO ( 93\%) transition, it could be assigned to mixed ${ }^{1} \mathrm{ILCT}\left[\pi-\pi^{*}(\mathrm{bzq})\right] /{ }^{1} \mathrm{MM}$ 'LCT $\left[\left(\mathrm{Pt} / \mathrm{AgPPh}_{3}\right) \rightarrow \pi^{*}(\mathrm{bzq})\right]$ transitions. In the dinuclear compound $\left[\left(\mathrm{C}_{6} \mathrm{~F}_{5}\right)(\mathrm{bzq})\left(\mathrm{CN}-2\right.\right.$-naphthyl)PtAg$\left.\left(\mathrm{PPh}_{3}\right)\right] \mathrm{ClO}_{4}$ (8), the lowest lying absorption involves the HOMO $\rightarrow$ LUMO ( 27.1\%) and H-1 $\rightarrow$ LUMO ( 65.2\%) transitions. In this case the $\mathrm{H}-1$ resembles the HOMO in $\mathbf{7}$ and $\mathbf{9}$, but the HOMO is constructed from orbitals of the CN-2-naphthyl ligand (97\%), so that the absorption band could be ascribed to mixed ${ }^{1} \operatorname{ILCT}\left[\pi-\pi^{*}\right.$ (bzq) $] /{ }^{1} \mathrm{MM}{ }^{\prime} \mathrm{LCT} \quad\left[\left(\mathrm{Pt} / \mathrm{AgPPh}_{3}\right)\right.$ $\left.\rightarrow \pi^{*}(\mathrm{bzq})\right] /{ }^{1} \mathrm{~L}$ 'LCT $\left[\mathrm{CNR} \rightarrow \pi^{*}\right.$ (bzq)] transition. In these dinuclear Pt/Ag complexes contrarily to what is observed in complexes $\left[\left\{\mathrm{Pt}(\mathrm{bzq})\left(\mathrm{C}_{6} \mathrm{~F}_{5}\right)_{2}\right\} \mathrm{AgL}\right]\left(\mathrm{L}=\mathrm{PPh}_{3}\right.$, tht $)$ or $\left[\left(\mathrm{C}_{6} \mathrm{~F}_{5}\right)(\mathrm{bzq})\left(\mathrm{PPh}_{3}\right) \mathrm{PtAg}\left(\mathrm{pyPh}_{2}\right)\right]\left(\mathrm{pyPh}_{2}=2\right.$,6-diphenylpyridine) the formation of the 
Pt-Ag bond does not increase the weight of the $\mathrm{C}_{6} \mathrm{~F}_{5}$ orbitals in the HOMO, but it also leads to the stabilization of the HOMO and LUMO orbitals and changes the nature of the electronic transitions with respect to their precursors. In these cases the effect on the transitions energy is also quite small, and appear shifted to lower energies.

In the trinuclear $\left[\mathrm{Pt}_{2} \mathrm{Ag}\right]$ clusters $\left[\left\{\mathrm{Pt}\left(\mathrm{C}_{6} \mathrm{~F}_{5}\right)(\mathrm{bzq})(\mathrm{CNR})\right\}_{2} \mathrm{Ag}\right] \mathrm{ClO}_{4} \quad \mathrm{R}=\mathrm{Me}$ (4Me), Ph (5Ph) $\}$ the HOMO is mostly constructed from orbitals located on the bzq ( $57 \%)$, the platinum ( $25 \%)$ and silver centers (12\%). Insignificant contributions of $\mathrm{C}_{6} \mathrm{~F}_{5}(\sim 2 \%)$ and CNR ( 4\%) are observed. The LUMO is similar to the HOMO but it shows a higher contribution of the Ag orbitals ( 24\%) along with lower contribution of those of the Pt center (10\%). In these compounds the lowest lying absorption involves the HOMO $\rightarrow$ LUMO (89\%) transition with a mixed ${ }^{1}$ ILCT $\left[\pi-\pi^{*}\right.$ (bzq) $] /{ }^{1}$ MLM'CT $[(\mathrm{Pt} / \mathrm{bzq} \rightarrow \mathrm{Ag}]$ character. The nature of the $\mathrm{R}$ group in the CNR ligand does not significantly affect the composition or the energy of the FOs and thus the transition energy.

In the simulated tetranuclear complex $\left[\left\{\mathrm{Pt}\left(\mathrm{C}_{6} \mathrm{~F}_{5}\right)(\mathrm{bzq})(\mathrm{CNPh}) \mathrm{Ag}\right\}_{2}\right]\left(\mathrm{ClO}_{4}\right)_{2}(\mathbf{6 P h})$ the HOMO is mostly constructed from orbitals located on the bzq (67\%), the platinum $(\sim 10 \%)$ and the silver centers (15\%). Insignificant contributions of $\mathrm{C}_{6} \mathrm{~F}_{5}(2 \%)$ and $\mathrm{CNPh}(5 \%)$ are observed. Surprisingly the LUMO shows a low contribution of the $\pi^{*}$ orbital of the bzq group (29\%) and a high contribution of the metal orbitals (30\% Ag, $26 \% \mathrm{Pt})$. Contributions of $\mathrm{C}_{6} \mathrm{~F}_{5}(8 \%)$ and $\mathrm{CNPh}(7 \%)$ orbitals are also scarce. The great increase of the metallic character along with the decrease of the bzq in the construction of the LUMO with respect to the di- and tri-nuclear complexes could be due to the existing $\mathrm{Pt}_{2} \mathrm{Ag}_{2}$ core with $\mathrm{Ag} \cdots \mathrm{Ag}$ contacts added to the Pt-Ag bonds. In complex $\mathbf{6} \mathbf{P h}$ the lowest lying absorption involves the HOMO $\rightarrow$ LUMO (92.2\%) transition with a mixed ${ }^{1} \mathrm{LMM}{ }^{\prime} \mathrm{CT}\left[(\mathrm{bzq} \rightarrow \mathrm{Pt} / \mathrm{Ag}] /{ }^{1} \mathrm{ILCT}\left[\pi-\pi^{*}\right.\right.$ (bzq) $]$ character.

\section{Conclusions}

The complexes $\left[\mathrm{Pt}\left(\mathrm{C}_{6} \mathrm{~F}_{5}\right)(\mathrm{bzq})(\mathrm{CNR})\right]\left\{\mathrm{R}={ }^{t} \mathrm{Bu}\right.$ (1), 2-naphthyl (2), 2,6-Me $\mathrm{Mh}_{2}$ (3) \} have been shown to be adequate precursors in the synthesis of $\mathrm{Pt} \rightarrow \mathrm{Ag}$ clusters, despite their neutral character. In their reactions with $\mathrm{AgClO}_{4}$, the $\mathrm{Pt} / \mathrm{Ag}$ relationship in the resulting complex does not depend on the ratio used, but rather it seems to be determined by steric factors. Thus, trinuclear "sandwich" clusters $\left[\left\{\mathrm{Pt}\left(\mathrm{C}_{6} \mathrm{~F}_{5}\right)(\mathrm{bzq})(\mathrm{CNR})\right\}_{2} \mathrm{Ag}\right] \mathrm{ClO}_{4}\left\{\mathrm{R}={ }^{t} \mathrm{Bu}\right.$ (4), 2-naphthyl (5) $\}$ or the tetranuclear 
$\left[\left\{\mathrm{Pt}\left(\mathrm{C}_{6} \mathrm{~F}_{5}\right)(\mathrm{bzq})\left(\mathrm{CN}-2,6-\mathrm{Me}_{2} \mathrm{Ph}\right) \mathrm{Ag}\right\}_{2}\right]\left(\mathrm{ClO}_{4}\right)_{2} \quad$ (6) are obtained. A “ $\mathrm{Pt}_{2} \mathrm{Ag}_{2}$ ” configuration as found in $\mathbf{6}$ allows for a bigger separation of the isocyanide residue from the core of the complex, avoiding steric repulsions, which may be favourable in the case of the 2,6-dimethylphenyl fragment of the isocyanide ligand of $\mathbf{6}$ that is bulkier than the equivalent ${ }^{t} \mathrm{Bu}$ or 2-naphthyl in $\mathbf{4}$ or $\mathbf{5}$.

Complexes 1-3 also react with $\left[\mathrm{Ag}\left(\mathrm{OClO}_{3}\right)\left(\mathrm{PPh}_{3}\right)\right]$ producing the dinuclear complexes $\left[\left(\mathrm{C}_{6} \mathrm{~F}_{5}\right)(\mathrm{bzq})(\mathrm{CNR}) \mathrm{PtAg}\left(\mathrm{PPh}_{3}\right)\right] \mathrm{ClO}_{4}\left\{\mathrm{R}={ }^{t} \mathrm{Bu}\right.$, (7), 2-naphthyl (8), 2,6$\mathrm{Me}_{2} \mathrm{Ph}$ (9) $\}$ which contain $\mathrm{Pt} \rightarrow \mathrm{Ag}$ bonds. These complexes seem to be less stable than the tri or tetranuclear 4-6, given that their NMR spectra indicate the existence of equilibriums in solution that involve the formation and rupture of the Pt-Ag bond. Moreover, the solutions of the dinuclear 7-9 evolve to more thermodynamically stable products, among which the trinuclear $\mathbf{4}$ and $\mathbf{5}$ have been identified. The higher stability of these complexes could be explained in terms of the electronic density received by the acidic silver center. In the trinuclear complexes the Ag is simultaneously bonded to two Pt donor atoms. Moreover, in all the silver complexes described here, the Ag center establishes $\eta^{1}$ interaction with the $C_{i p s o}$ of the bzq ligand, except for $\mathbf{6}$ where the interaction is di-hapto with the bzq of the other " $\left(\mathrm{C}_{6} \mathrm{~F}_{5}\right)(\mathrm{bzq})\left(\mathrm{CN}-2,6-\mathrm{Me}_{2} \mathrm{Ph}\right) \mathrm{PtAg}$ " subunit and in several cases (4b, 5, 6 and 7) there are additional Ag-O contacts with solvent acetone molecules or perchlorate anions. This would seem to indicate that the silver center completes its electronic requirements from several sources, and that the dative $\mathrm{Pt} \rightarrow \mathrm{Ag}$ bond alone may not be sufficient to fulfil its requirements.

The Pt/Ag compounds 4-9 are not emissive in solution but they are in rigid matrix. In glassy 2-Me-THF or $\mathrm{CH}_{2} \mathrm{Cl}_{2}$ at $77 \mathrm{~K}$ at any concentration $\left(10^{-3} \mathrm{M}, 10^{-4} \mathrm{M}, 10^{-5} \mathrm{M}\right)$ they show the same emission spectra as their corresponding starting complexes 1-3 in agreement with the cleavage of the Pt-Ag bonds. In the solid state only the dinuclear compounds $\left[\mathrm{Pt}\left(\mathrm{C}_{6} \mathrm{~F}_{5}\right)(\mathrm{bzq})\left(\mathrm{CN}-{ }^{t} \mathrm{Bu}\right) \mathrm{AgPPh}_{3}\right] \mathrm{ClO}_{4} \quad$ (7) and $\left[\mathrm{Pt}\left(\mathrm{C}_{6} \mathrm{~F}_{5}\right)(\mathrm{bzq})(\mathrm{CN}-2,6-\right.$ $\left.\left.\mathrm{Me}_{2} \mathrm{Phl}\right) \mathrm{AgPPh}_{3}\right] \mathrm{ClO}_{4}(\mathbf{9})$ together with the tetranuclear complex $\left[\left\{\mathrm{Pt}\left(\mathrm{C}_{6} \mathrm{~F}_{5}\right)(\mathrm{bzq})(\mathrm{CN}-\right.\right.$ 2,6- $\left.\left.\mathrm{Me}_{2} \mathrm{Ph}\right) \mathrm{Ag}_{2}\right]\left(\mathrm{ClO}_{4}\right)_{2}(6)$ are emissive at room temperature showing bright greenish (7, 9) or yellowish (6) phosphorescence. In all three compounds a significant contribution of $\mathrm{M}$ 'orbitals $\left(\mathrm{AgPPh}_{3} / \mathrm{Ag}\right)$ to the FOs has been observed, and their main emissions seem to arise from mixed excited states ${ }^{3} \operatorname{ILCT}\left(\pi-\pi^{*}\right.$ (bzq))/ ${ }^{3}$ MM'LCT $\left(\mathrm{Pt} / \mathrm{AgPPh}_{3} \rightarrow\right.$ bzq) $(\mathbf{7}, \mathbf{9})$ or ${ }^{3} \mathrm{LMM}{ }^{\prime} \mathrm{CT}[(\mathrm{bzq}) \rightarrow \mathrm{Pt} / \mathrm{Ag}] /{ }^{3} \mathrm{ILCT}\left[\pi-\pi^{*}\right.$ (bzq)] (6) in nature. 


\section{Experimental}

\subsection{Material and Instrumentation}

Literature methods were used to prepare the starting material $\left[\mathrm{Pt}\left(\mathrm{C}_{6} \mathrm{~F}_{5}\right)(\mathrm{bzq})\left(\mathrm{Me}_{2} \mathrm{CO}\right)\right](\mathbf{1}) .{ }^{58}$ Elemental analyses were carried out with a Perkin-Elmer 2400 CHNS analyzer. IR spectra were recorded on a Perkin-Elmer Spectrum 100 FT-IR spectrometer (ATR in the range 250-4000 $\mathrm{cm}^{-1}$ ). Mass spectrometry was performed with the Microflex matrix-assisted laser desorption ionization-time-of-flight (MALDITOF) Bruker or an Autoflex III MALDI-TOF Bruker instruments. Molar conductances were carried out on a Philiphs PW9509 conductimeter in acetone solution $\left(5 \times 10^{-4} \mathrm{M}\right)$. NMR spectra in solution were recorded at 298K on Bruker Avance 400 spectrometer with $\mathrm{SiMe}_{4}, \mathrm{CFCl}_{3}$ and $85 \% \mathrm{H}_{3} \mathrm{PO}_{4}$ as external references for ${ }^{1} \mathrm{H},{ }^{19} \mathrm{~F}$ and ${ }^{31} \mathrm{P}$ respectively.

The NMR spectral assignments follow the numbering in Scheme 3.
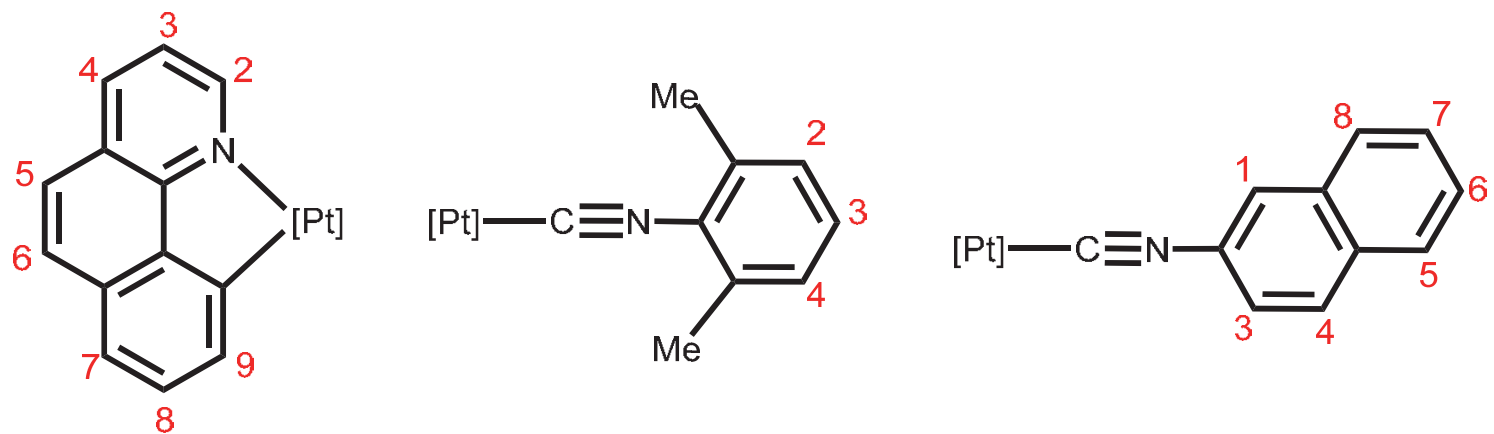

Scheme 3. Atom numbering schemes for the ligands used in this work.

Diffuse reflectance UV-vis (DRUV) spectra were recorded on a Thermo electron corporation evolution 600 spectrophotometer equipped with a Praying Mantis integrating sphere. The solid samples were homogeneously diluted with silica. The mixtures were placed in a homemade cell equipped with quartz window. Steady-state photoluminescence spectra were recorded on a Jobin-Yvon Horiba Fluorolog FL-3-11 Tau 3 spectrofluorimeter using band pathways of $3 \mathrm{~nm}$ for both excitation and emission. Phosphorescence lifetimes were recorded with a Fluoromax phosphorimeter accessory containing a UV xenon flash tube with a flash rate between 0.05 and $25 \mathrm{~Hz}$. Phase shift and modulation were recorded over the frequency range of 0.1-100 $\mathrm{MHz}$. The quantum 
efficiency was determined by using Quantaurus quantum yield equipment from Hamamatsu model C11347-11.

Safety Note: Perchlorate salts of metal complexes with organic ligands are potentially explosive. Only small amounts of material should be prepared and these should be handled with great caution.

\subsection{Syntheses of the complexes}

Preparation of $\left[\mathrm{Pt}\left(\mathrm{C}_{6} \mathrm{~F}_{5}\right)(\mathrm{bzq})(\mathrm{CNR})\right]\left\{\mathrm{R}={ }^{t} \mathrm{Bu},(1)\right.$, 2-naphthyl(2), 2,6-Me $2 \mathrm{Ph}$ (3) $\}$. To a solution of $\left[\mathrm{Pt}(\mathrm{bzq})\left(\mathrm{C}_{6} \mathrm{~F}_{5}\right)\left(\mathrm{Me}_{2} \mathrm{CO}\right)\right](0.200 \mathrm{~g}, 0.335 \mathrm{mmol})$ in $\mathrm{Me}_{2} \mathrm{CO}(25 \mathrm{~mL})$ at $0^{\circ} \mathrm{C}$ and under Ar atmosphere, $0.335 \mathrm{mmol}$ of $\mathrm{CNR}\left(\mathrm{R}={ }^{t} \mathrm{Bu}, 37.80 \mu \mathrm{L}\right.$; 2-naphthyl, $0.051 \mathrm{~g} ; 2,6-\mathrm{Me}_{2} \mathrm{Ph}, 0.044 \mathrm{~g}$ ) was added. After $2 \mathrm{~min}$ of stirring the solution was concentrated until ca. $2 \mathrm{~mL}$. The yellow precipitate which appeared was filtered off, washed with $n$-hexane $(10 \mathrm{~mL})$ and air dried.

[Pt( $\left.\left.\mathbf{C}_{6} \mathbf{F}_{5}\right)(\mathbf{b z q})\left(\mathbf{C N}^{t} \mathbf{B u}\right)\right]$ (1). 0.174 g, 83.5\% yield. Anal. Found (calcd for $\mathrm{C}_{24} \mathrm{H}_{17} \mathrm{~F}_{5} \mathrm{~N}_{2} \mathrm{Pt}$ ): C, 46.01 (46.28); H, 2.99 (2.75); N, 4.85 (4.49). IR (cm $\left.{ }^{-1}\right): 2169$ (m, v $\mathrm{NC}_{\text {) }} 1496(\mathrm{~m}), 1453$ (m), 1439 (m), 1202 (w), 1058 (m), 952 (s), 797 (m, C $6 \mathrm{~F}_{5}, \mathrm{X}-$ sensitive vibr.) ${ }^{88} \cdot \Lambda_{M}$ (acetone) $=5.08 \Omega^{-1} \mathrm{~cm}^{2} \mathrm{~mol}^{-1} .{ }^{1} \mathrm{H}$ NMR (Acetone- $\mathrm{d}_{6}, 298 \mathrm{~K}$ ): $\delta$ $9.26\left(1 \mathrm{H}, \mathrm{dd},{ }^{3} J_{\mathrm{H} 2-\mathrm{H} 3}=5.2 \mathrm{~Hz},{ }^{4} J_{\mathrm{H} 2-\mathrm{H} 4}=1.4 \mathrm{~Hz},{ }^{3} J_{\mathrm{H} 2-\mathrm{Pt}}=26.3 \mathrm{~Hz}, \mathrm{H} 2\right), 8.72(1 \mathrm{H}, \mathrm{dd}$, $\left.{ }^{3} J_{\mathrm{H} 4-\mathrm{H} 3}=8.1 \mathrm{~Hz},{ }^{4} J_{\mathrm{H} 4-\mathrm{H} 2}=1.4 \mathrm{~Hz}, \mathrm{H} 4\right), 7.89\left(1 \mathrm{H}, \mathrm{d},{ }^{3} J_{\mathrm{H} 6-\mathrm{H} 5}=8.8 \mathrm{~Hz}, \mathrm{H} 6\right), 7.78(1 \mathrm{H}, \mathrm{d}$, $\left.{ }^{3} J_{\mathrm{H} 5-\mathrm{H} 6}=8.8 \mathrm{~Hz}, \mathrm{H} 5\right), 7.78\left(1 \mathrm{H}, \mathrm{dd},{ }^{3} J_{\mathrm{H} 3-\mathrm{H} 4}=8.1 \mathrm{~Hz},{ }^{3} J_{\mathrm{H} 3-\mathrm{H} 2}=5.2 \mathrm{~Hz}, \mathrm{H} 3\right), 7.66(1 \mathrm{H}$, $\left.\mathrm{dd},{ }^{3} J_{\mathrm{H} 7-\mathrm{H} 8}=8.0 \mathrm{~Hz},{ }^{4} J_{\mathrm{H} 7-\mathrm{H} 9}=0.9 \mathrm{~Hz}, \mathrm{H} 7\right), 7.43\left(1 \mathrm{H}, \mathrm{dd},{ }^{3} J_{\mathrm{H} 8-\mathrm{H} 9}=7.1 \mathrm{~Hz},{ }^{3} J_{\mathrm{H} 8-\mathrm{H} 7}=8.0\right.$ $\mathrm{Hz}, \mathrm{H} 8), 7.08\left(1 \mathrm{H}, \mathrm{d},{ }^{3} J_{\mathrm{H} 9-\mathrm{H} 8}=7.1 \mathrm{~Hz},{ }^{3} J_{\mathrm{H} 9-\mathrm{Pt}}=49.7 \mathrm{~Hz}, \mathrm{H} 9\right), 1.63\left(9 \mathrm{H}, \mathrm{s}, \mathrm{CN}^{t} \mathrm{Bu}_{-} \mathrm{CH}_{3}\right)$. ${ }^{19} \mathrm{~F}$ NMR (Acetone- $\left.\mathrm{d}_{6}, 298 \mathrm{~K}\right): \delta-118.40\left(2 o-\mathrm{F}, \mathrm{m},{ }^{3} J_{\mathrm{F}-\mathrm{Pt}}=471.1 \mathrm{~Hz}\right), 166.73(p-\mathrm{F}$, t), $-167.94(2 m-F$, br $\mathrm{m})$. Mass spectra MALDI+ DIT: $\mathrm{m} / \mathrm{z}=622$ $\left[\mathrm{Pt}\left(\mathrm{C}_{13} \mathrm{H}_{8} \mathrm{~N}\right)\left(\mathrm{C}_{6} \mathrm{~F}_{5}\right)\left(\mathrm{C}_{4} \mathrm{H}_{9} \mathrm{CN}\right)-\mathrm{H}\right]^{+}, \quad 456 \quad\left[\mathrm{Pt}\left(\mathrm{C}_{13} \mathrm{H}_{8} \mathrm{~N}\right)\left(\mathrm{C}_{4} \mathrm{H}_{9} \mathrm{CN}\right)\right]^{+}, \quad 400$ $\left[\mathrm{Pt}\left(\mathrm{C}_{13} \mathrm{H}_{8} \mathrm{~N}\right)(\mathrm{CNH})\right]^{+}$.

[Pt $\left.\left(\mathbf{C}_{6} \mathbf{F}_{5}\right)(\mathbf{b z q})(\mathbf{C N}-2-n a p h t h y l)\right]$ (2). 0.189 g, 81.5\% yield. Anal. Found (calcd for $\mathrm{C}_{30} \mathrm{H}_{15} \mathrm{~F}_{5} \mathrm{~N}_{2} \mathrm{Pt}$ ): C, 51.77 (51.95); H, 2.41 (2.55); N, 4.01 (4.04). IR (cm-1): 2163 (s, v $\mathrm{NC}_{\mathrm{NC}}$, 1498 (m), 1450 (m), 1437 (m), 1059 (m), 953 (s), 808 (m, C $\mathrm{F}_{5}$, X-sensitive vibr.) ${ }^{88} . \Lambda_{\mathrm{M}}$ (acetone) $=8.56 \Omega^{-1} \mathrm{~cm}^{2} \mathrm{~mol}^{-1} .{ }^{1} \mathrm{H}$ NMR (Acetone-d $\left.\mathrm{d}_{6}, 298 \mathrm{~K}\right): \delta 9.55(1 \mathrm{H}$, $\left.\mathrm{dd},{ }^{3} J_{\mathrm{H} 2-\mathrm{H} 3}=5.2 \mathrm{~Hz},{ }^{4} J_{\mathrm{H} 2-\mathrm{H} 4}=1.4 \mathrm{~Hz},{ }^{3} J_{\mathrm{H} 2-\mathrm{Pt}}=26.4 \mathrm{~Hz}, \mathrm{H} 2\right), 8.76\left(1 \mathrm{H}, \mathrm{dd},{ }^{3} J_{\mathrm{H} 4-\mathrm{H} 3}=8.1\right.$ $\left.\mathrm{Hz},{ }^{4} J_{\mathrm{H} 4-\mathrm{H} 2}=1.4 \mathrm{~Hz}, \mathrm{H} 4\right), 8.36\left(1 \mathrm{H}, \mathrm{d},{ }^{3} J_{\mathrm{H} 1-\mathrm{H} 3}=2.0 \mathrm{~Hz}, \mathrm{CN}-2-\right.$ naphthyl-H1), $8.12(1 \mathrm{H}$, 
d, $\left.{ }^{3} J_{\mathrm{H} 4-\mathrm{H} 3}=8.7 \mathrm{~Hz}, \mathrm{CN}-2-n a p h t h y l-H 4\right), 8.07-8.03$ (2H, m, CN-2-naphthyl-H6 and H7), $7.93\left(1 \mathrm{H}, \mathrm{d},{ }^{3} J_{\mathrm{H} 5-\mathrm{H} 6}=8.8 \mathrm{~Hz}, \mathrm{H} 5\right), 7.82\left(1 \mathrm{H}, \mathrm{d},{ }^{3} J_{\mathrm{H} 6-\mathrm{H} 5}=8.8 \mathrm{~Hz}, \mathrm{H} 6\right), 7.81\left(1 \mathrm{H}, \mathrm{dd},{ }^{3} J_{\mathrm{H} 3-}\right.$ $\left.\mathrm{H}_{4}=8.1 \mathrm{~Hz},{ }^{3} J_{\mathrm{H} 3-\mathrm{H} 2}=5.2 \mathrm{~Hz}, \mathrm{H} 3\right), 7.75\left(1 \mathrm{H}, \mathrm{dd},{ }^{3} J_{\mathrm{H} 3-\mathrm{H} 4}=8.7 \mathrm{~Hz},{ }^{4} J_{\mathrm{H} 3-\mathrm{H} 1}=2.0 \mathrm{~Hz}, \mathrm{CN}-\right.$ 2-Np-H3), 7.71 (3H, m, bzq-H7 overlapped with CN-2-naphthyl-H5 and CN-2naphthyl-H8), $7.48\left(1 \mathrm{H}, \mathrm{dd},{ }^{3} J_{\mathrm{H} 8-\mathrm{H} 9}=7.0 \mathrm{~Hz},{ }^{3} J_{\mathrm{H} 8-\mathrm{H} 7}=8.0 \mathrm{~Hz}, \mathrm{H} 8\right), 7.11\left(1 \mathrm{H}, \mathrm{d},{ }^{3} J_{\mathrm{H} 9-\mathrm{H} 8}\right.$ $\left.=7.1 \mathrm{~Hz},{ }^{3} \mathrm{~J}_{\mathrm{Pt}-\mathrm{H} 9}=48.8 \mathrm{~Hz}, \mathrm{H} 9\right) .{ }^{19} \mathrm{~F}$ NMR (Acetone-d $\left.\mathrm{d}_{6}, 298 \mathrm{~K}\right): \delta-118.34(2 o-\mathrm{F}, \mathrm{m}$, $\left.{ }^{3} J_{\mathrm{F}-\mathrm{Pt}}=465.7 \mathrm{~Hz}\right), 166.26(p-\mathrm{F}, \mathrm{t}),-167.51(2 m-\mathrm{F}, \mathrm{br} \mathrm{m})$. Mass spectra MALDI+ DIT: $\mathrm{m} / \mathrm{z}=679\left[\mathrm{Pt}\left(\mathrm{C}_{13} \mathrm{H}_{8} \mathrm{~N}\right)\left(\mathrm{C}_{10} \mathrm{H}_{7} \mathrm{CN}\right)_{2}\right], 526\left[\mathrm{Pt}\left(\mathrm{C}_{13} \mathrm{H}_{8} \mathrm{~N}\right)\left(\mathrm{C}_{10} \mathrm{H}_{7} \mathrm{CN}\right)\right]^{+}$.

[Pt( $\left.\left.\mathbf{C}_{6} \mathbf{F}_{5}\right)(\mathbf{b z q})\left(\mathbf{C N}-2,6-\mathbf{M e}_{2} \mathbf{P h}\right)\right]$ (3). 0.180 g, 80.2\% yield. Anal. Found (calcd for $\mathrm{C}_{28} \mathrm{H}_{17} \mathrm{~F}_{5} \mathrm{~N}_{2} \mathrm{Pt}$ ): C, 50.08 (50.08); H, 2.83 (2.55); N, 4.15 (4.17). IR (cm ${ }^{-1}$ ): 2154 (s, v $\mathrm{NC}_{\mathrm{NC}}, 1499$ (m), 1456 (m), 1442 (m), 1059 (m), 954 (s), 799 (m, C6 $\mathrm{F}_{5}$, X-sensitive vibr.) ${ }^{88} . \Lambda_{\mathrm{M}}$ (acetone) $=17.01 \Omega^{-1} \mathrm{~cm}^{2} \mathrm{~mol}^{-1} .{ }^{1} \mathrm{H}$ NMR (Acetone- $\left.\mathrm{d}_{6}, 298 \mathrm{~K}\right): \delta 9.51(1 \mathrm{H}$, $\left.\mathrm{dd},{ }^{3} J_{\mathrm{H} 2-\mathrm{H} 3}=5.2 \mathrm{~Hz},{ }^{4} J_{\mathrm{H} 2-\mathrm{H} 4}=1.4 \mathrm{~Hz},{ }^{3} J_{\mathrm{H} 2-\mathrm{Pt}}=26.4 \mathrm{~Hz}, \mathrm{H} 2\right), 8.76\left(1 \mathrm{H}, \mathrm{dd},{ }^{3} J_{\mathrm{H} 4-\mathrm{H} 3}=8.1\right.$ $\left.\mathrm{Hz},{ }^{4} J_{\mathrm{H} 4-\mathrm{H} 2}=1.4 \mathrm{~Hz}, \mathrm{H} 4\right), 7.93\left(1 \mathrm{H}, \mathrm{d},{ }^{3} J_{\mathrm{H} 5-\mathrm{H} 6}=8.8 \mathrm{~Hz}, \mathrm{H} 5\right), 7.83\left(1 \mathrm{H}, \mathrm{dd},{ }^{3} J_{\mathrm{H} 3-\mathrm{H} 4}=8.1\right.$ $\left.\mathrm{Hz},{ }^{3} J_{\mathrm{H} 3-\mathrm{H} 2}=5.2 \mathrm{~Hz}, \mathrm{H} 3\right), 7.81\left(1 \mathrm{H}, \mathrm{d},{ }^{3} J_{\mathrm{H} 6-\mathrm{H} 5}=8.8 \mathrm{~Hz}, \mathrm{H} 6\right), 7.70\left(1 \mathrm{H}, \mathrm{dd},{ }^{3} J_{\mathrm{H} 7-\mathrm{H} 8}=8.0\right.$ $\left.\mathrm{Hz},{ }^{4} J_{\mathrm{H} 7-\mathrm{H} 9}=0.9 \mathrm{~Hz}, \mathrm{H} 7\right), 7.48\left(1 \mathrm{H}, \mathrm{dd},{ }^{3} J_{\mathrm{H} 8-\mathrm{H} 9}=7.1 \mathrm{~Hz},{ }^{3} J_{\mathrm{H} 8-\mathrm{H} 7}=8.0 \mathrm{~Hz}, \mathrm{H} 8\right), 7.37$ $\left(1 \mathrm{H}, \mathrm{dd},{ }^{3} J_{\mathrm{H} 3-\mathrm{H} 2}={ }^{3} J_{\mathrm{H} 3-\mathrm{H} 2^{\prime}}=8.2 \mathrm{~Hz}, \mathrm{CN}-2,6-\mathrm{Me}_{2} \mathrm{Ph}-\mathrm{H} 3\right), 7.27\left(2 \mathrm{H}, \mathrm{dd},{ }^{3} J_{\mathrm{H} 2-\mathrm{H} 3}={ }^{3} J_{\mathrm{H} 2}-\mathrm{H} 3\right.$ $=8.2 \mathrm{~Hz},{ }^{4} J_{\mathrm{H} 2-\mathrm{H} 2^{\prime}}=0.6 \mathrm{~Hz}, \mathrm{CN}-2,6-\mathrm{Me}_{2} \mathrm{Ph}-\mathrm{H} 2$ and $\left.\mathrm{H} 2{ }^{\prime}\right), 7.11\left(1 \mathrm{H}, \mathrm{d},{ }^{3} J_{\mathrm{H} 9-\mathrm{H} 8}=7.1 \mathrm{~Hz}\right.$, $\left.{ }^{3} J_{\mathrm{H} 9-\mathrm{Pt}}=50.0 \mathrm{~Hz}, \mathrm{H} 9\right), 2.43$ (6H, s, CN-2,6-Me $2 \mathrm{Ph}^{\left.-\mathrm{CH}_{3}\right) .}{ }^{19} \mathrm{~F}$ NMR (Acetone-d 6 , $298 \mathrm{~K}$ ): $\delta-118.20\left(2 o-\mathrm{F}, \mathrm{m},{ }^{3} J_{\mathrm{F}-\mathrm{Pt}}=467.4 \mathrm{~Hz}\right), 166.22(p-\mathrm{F}, \mathrm{t}),-167.57$ (2m-F, br m). Mass spectra MALDI+ DIT: $\mathrm{m} / \mathrm{z}=635 \quad\left[\mathrm{Pt}\left(\mathrm{C}_{13} \mathrm{H}_{8} \mathrm{~N}\right)\left(\mathrm{C}_{8} \mathrm{H}_{9} \mathrm{CN}\right)_{2}\right], \quad 504$ $\left[\mathrm{Pt}\left(\mathrm{C}_{13} \mathrm{H}_{8} \mathrm{~N}\right)\left(\mathrm{C}_{8} \mathrm{H}_{9} \mathrm{CN}\right)\right]^{+}$.

\section{Preparation of $\left[\left\{\mathrm{Pt}\left(\mathrm{C}_{6} \mathrm{~F}_{5}\right)(\mathrm{bzq})(\mathrm{CNR})\right]\right\}_{2} \mathrm{Ag} \mathrm{ClO}_{4}\left\{\mathrm{R}={ }^{t} \mathrm{Bu}(4)\right.$, 2-naphthyl (5) $\}$. To a} solution of $\left[\mathrm{Pt}(\mathrm{bzq})\left(\mathrm{C}_{6} \mathrm{~F}_{5}\right)(\mathrm{CNR})\right]\left(\mathrm{R}={ }^{t} \mathrm{Bu}, 0.120 \mathrm{~g}, 0.193 \mathrm{mmol} ; \mathrm{R}=(2-\mathrm{Np}), 0.120 \mathrm{~g}\right.$, $0.173 \mathrm{mmol})$ in $\mathrm{Me}_{2} \mathrm{CO}\left(25 \mathrm{~mL}, \mathrm{R}={ }^{t} \mathrm{Bu} ; 60 \mathrm{~mL}, \mathrm{R}=2\right.$-naphthyl $)$ at $0^{\circ} \mathrm{C}$ and under $\mathrm{Ar}$ atmosphere, $\mathrm{AgClO}_{4}\left(\mathrm{R}={ }^{t} \mathrm{Bu}, 0.020 \mathrm{~g}, 0.096 \mathrm{mmol}\right.$; $\mathrm{R}=$ 2-naphthyl, $0.018 \mathrm{~g}, 0.086$ mmol) was added. After $30 \mathrm{~min}$ of stirring in absence of light the solution was concentrated until ca. $2 \mathrm{~mL}$. Over the resultant yellow suspension, $n$-hexane $(10 \mathrm{~mL})$ was added. The yellow precipitate was filtered off and air dried.

$\left[\left\{\mathbf{P t}\left(\mathbf{C}_{6} \mathbf{F}_{5}\right)(\mathbf{b z q})\left({ }^{t}{ }^{B u C N}\right)\right\}_{2} \mathrm{Ag} \mathrm{ClO}_{4}\right.$ (4). 0.112 g, 80.0\%. Anal. Found (calcd for $\mathrm{C}_{48} \mathrm{H}_{34} \mathrm{AgClF}_{10} \mathrm{~N}_{4} \mathrm{O}_{4} \mathrm{Pt}_{2}$ ): C, 39.39 (39.64); H, 2.43 (2.36); N, 3.91 (3.85). IR ( $\mathrm{cm}^{-1}$ ):

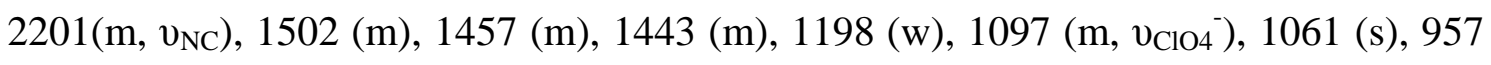
(s), $801\left(\mathrm{~m}, \mathrm{C}_{6} \mathrm{~F}_{5}, \mathrm{X} \text {-sensitive vibr. }\right)^{88}, 619\left(\mathrm{w}, \mathrm{v}_{\mathrm{ClO} 4}{ }^{-}\right) . \Lambda_{\mathrm{M}}$ (acetone) $=276.43 \Omega^{-}$ 
${ }^{1} \mathrm{~cm}^{2} \mathrm{~mol}^{-1} .{ }^{1} \mathrm{H}$ NMR (Acetone-d 6 , $\left.298 \mathrm{~K}\right): \delta 9.18\left(2 \mathrm{H}, \mathrm{dd},{ }^{3} \mathrm{~J}_{\mathrm{H} 2-\mathrm{H} 3}=5.2 \mathrm{~Hz},{ }^{4} \mathrm{~J}_{\mathrm{H} 2-\mathrm{H} 4}=1.3\right.$ $\left.\mathrm{Hz},{ }^{3} J_{\mathrm{H} 2-\mathrm{Pt}}=25.4 \mathrm{~Hz}, \mathrm{H} 2\right), 8.76\left(2 \mathrm{H}, \mathrm{dd},{ }^{3} J_{\mathrm{H} 4-\mathrm{H} 3}=8.2 \mathrm{~Hz},{ }^{4} J_{\mathrm{H} 4-\mathrm{H} 2}=1.3 \mathrm{~Hz}, \mathrm{H} 4\right), 7.92$ $\left(2 \mathrm{H}, \mathrm{d},{ }^{3} J_{\mathrm{H} 5-\mathrm{H} 6}=8.8 \mathrm{~Hz}, \mathrm{H} 5\right), 7.85\left(2 \mathrm{H}, \mathrm{d},{ }^{3} J_{\mathrm{H} 6-\mathrm{H} 5}=8.8 \mathrm{~Hz}, \mathrm{H6}\right), 7.83\left(2 \mathrm{H}, \mathrm{dd},{ }^{3} J_{\mathrm{H} 3-\mathrm{H} 4}=\right.$ $\left.8.2 \mathrm{~Hz},{ }^{3} J_{\mathrm{H} 3-\mathrm{H} 2}=5.2 \mathrm{~Hz}, \mathrm{H} 3\right), 7.78\left(2 \mathrm{H}, \mathrm{dd},{ }^{3} J_{\mathrm{H} 7-\mathrm{H} 8}=8.0 \mathrm{~Hz},{ }^{4} J_{\mathrm{H} 7-\mathrm{H} 9}=0.8 \mathrm{~Hz}, \mathrm{H} 7\right), 7.43$ $\left(2 \mathrm{H}, \mathrm{dd},{ }^{3} J_{\mathrm{H} 8-\mathrm{H9}}=7.0 \mathrm{~Hz},{ }^{3} J_{\mathrm{H} 8-\mathrm{H} 7}=8.0 \mathrm{~Hz}, \mathrm{H8}\right), 7.09\left(2 \mathrm{H}, \mathrm{d},{ }^{3} J_{\mathrm{H9}-\mathrm{H} 8}=7.0 \mathrm{~Hz},{ }^{3} J_{\mathrm{H9}-\mathrm{Pt}}=\right.$ $47.3 \mathrm{~Hz}, \mathrm{H} 9), 1.64$ (18H,s, $\left.\mathrm{CN}^{t} \mathrm{Bu}-\mathrm{CH}_{3}\right) .{ }^{19} \mathrm{~F}$ NMR (Acetone- $\mathrm{d}_{6}, 298 \mathrm{~K}$ ): $\delta-117.69$ (4o$\left.\mathrm{F},{ }^{3} J_{\mathrm{F}-\mathrm{Pt}}=463.6 \mathrm{~Hz}\right), 166.14(2 p-\mathrm{F}, \mathrm{t}),-167.57$ (4m-F, br m). Mass spectra MALDI+ DCTB: $\quad \mathrm{m} / \mathrm{z}=1353 \quad\left[\left(\mathrm{Pt}_{2}\left(\mathrm{C}_{13} \mathrm{H}_{8} \mathrm{~N}\right)_{2}\left(\mathrm{C}_{6} \mathrm{~F}_{5}\right)_{2}\left(\mathrm{C}_{4} \mathrm{H}_{9} \mathrm{CN}\right)_{2}\right) \mathrm{Ag}\right]^{+}, \quad 730$ $\left[\mathrm{Pt}\left(\mathrm{C}_{13} \mathrm{H}_{8} \mathrm{~N}\right)\left(\mathrm{C}_{4} \mathrm{H}_{9} \mathrm{CN}\right)\left(\mathrm{C}_{6} \mathrm{~F}_{5}\right) \mathrm{Ag}\right]^{+}, 456\left[\mathrm{Pt}\left(\mathrm{C}_{13} \mathrm{H}_{8} \mathrm{~N}\right)\left(\mathrm{C}_{4} \mathrm{H}_{9} \mathrm{CN}\right)\right]^{+}$.

[\{Pt( $\left.\left.\mathbf{C}_{6} \mathbf{F}_{5}\right)(\mathbf{b z q})(2-n a p h t h y l)\right\}_{2} \mathrm{Ag}_{\mathbf{C}} \mathbf{C l O}_{4}$ (5). $0.117 \mathrm{~g}, 84.5 \%$ yield. Anal. Found (calcd for $\mathrm{C}_{60} \mathrm{H}_{30} \mathrm{AgClF}_{10} \mathrm{~N}_{4} \mathrm{O}_{4} \mathrm{Pt}_{2}$ ): C, 45.67 (45.20); H, 2.26 (1.90); N, 3.51 (3.51). IR $\left(\mathrm{cm}^{-1}\right)$ : $2174\left(\mathrm{~m}, \mathrm{v}_{\mathrm{NC}}\right), 1501(\mathrm{~m}), 1459(\mathrm{~m}), 1448$ (m), 1100 (w, $\left.v_{\mathrm{ClO}}{ }^{-}\right), 1060$ (s), 956 (s), 800 (m, $\mathrm{C}_{6} \mathrm{~F}_{5}, \mathrm{X}$-sensitive vibr. $)^{88}, 622\left(\mathrm{w}, \mathrm{v}_{\mathrm{ClO}{ }^{-}}\right) . \Lambda_{\mathrm{M}}$ (acetone) $=249.50 \Omega^{-1} \mathrm{~cm}^{2} \mathrm{~mol}^{-1} .{ }^{1} \mathrm{H}$ NMR (Acetone-d $6,298 \mathrm{~K}): \delta 9.56\left(2 \mathrm{H}, \mathrm{dd},{ }^{3} J_{\mathrm{H} 2-\mathrm{H} 3}=5.2 \mathrm{~Hz},{ }^{4} J_{\mathrm{H} 2-\mathrm{H} 4}=1.43 \mathrm{~Hz},{ }^{3} J_{\mathrm{H} 2-\mathrm{Pt}}=\right.$ $25.6 \mathrm{~Hz}, \mathrm{H} 2), 8.78\left(2 \mathrm{H}, \mathrm{dd},{ }^{3} J_{\mathrm{H} 4-\mathrm{H} 3}=8.1 \mathrm{~Hz},{ }^{4} J_{\mathrm{H} 4-\mathrm{H} 2}=1.3 \mathrm{~Hz}, \mathrm{H} 4\right), 8.37\left(2 \mathrm{H}, \mathrm{d},{ }^{3} J_{\mathrm{H} 1-\mathrm{H} 3}\right.$ $=2.0 \mathrm{~Hz}, \mathrm{CN}-2$-naphthyl-H1), $8.13\left(2 \mathrm{H}, \mathrm{d},{ }^{3} J_{\mathrm{H} 4-\mathrm{H} 3}=8.8 \mathrm{~Hz}, \mathrm{CN}-2\right.$-naphthyl-H4), 8.088.04 (4H, m, CN-2-naphthyl-H6 and H7), $7.95\left(2 \mathrm{H}, \mathrm{d},{ }^{3} \mathrm{~J}_{\mathrm{H} 5-\mathrm{H} 6}=8.8 \mathrm{~Hz}, \mathrm{H} 5\right), 7.95(2 \mathrm{H}$, d, $\left.{ }^{3} J_{\mathrm{H} 5-\mathrm{H} 6}=8.8 \mathrm{~Hz}, \mathrm{H} 5\right), 7.84\left(2 \mathrm{H}, \mathrm{d},{ }^{3} J_{\mathrm{H} 6-\mathrm{H} 5}=8.8 \mathrm{~Hz}, \mathrm{H} 6\right), 7.83\left(2 \mathrm{H}, \mathrm{dd},{ }^{3} J_{\mathrm{H} 3-\mathrm{H} 4}=8.1\right.$ $\left.\mathrm{Hz},{ }^{3} J_{\mathrm{H} 3-\mathrm{H} 2}=5.2 \mathrm{~Hz}, \mathrm{H} 3\right), 7.75\left(2 \mathrm{H}, \mathrm{dd},{ }^{3} J_{\mathrm{H} 3-\mathrm{H} 4}=8.7 \mathrm{~Hz},{ }^{4} J_{\mathrm{H} 3-\mathrm{H} 1}=2.0 \mathrm{~Hz}, \mathrm{CN}-2-\right.$ naphthyl-H3), 7.72-7.66 (6H, m, bzq-H7 overlapped CN-2-naphthyl-H5 and CN-2naphthyl-H8), 7.50 (2H, dd, $\left.{ }^{3} J_{\mathrm{H} 8-\mathrm{H} 9}=7.0 \mathrm{~Hz},{ }^{3} J_{\mathrm{H} 8-\mathrm{H} 7}=7.9 \mathrm{~Hz}, \mathrm{H8}\right), 7.14\left(2 \mathrm{H}, \mathrm{d},{ }^{3} J_{\mathrm{H}-\mathrm{H} 8}\right.$ $\left.=7.0 \mathrm{~Hz},{ }^{3} J_{\mathrm{Hg}-\mathrm{Pt}}=48.7 \mathrm{~Hz}, \mathrm{H} 9\right) .{ }^{19} \mathrm{~F}$ NMR (Acetone- $\left.\mathrm{d}_{6}, 298 \mathrm{~K}\right): \delta-118.07\left(20-\mathrm{F},{ }^{3} J_{\mathrm{F}-\mathrm{Pt}}\right.$ $=465.0 \mathrm{~Hz}$ ), 166.04 ( $p-\mathrm{F}, \mathrm{t}),-167.36$ (2m-F, br m). Mass spectra MALDI+ DCTB: m/z $=1494\left[\left(\mathrm{Pt}_{2}\left(\mathrm{C}_{13} \mathrm{H}_{8} \mathrm{~N}\right)_{2}\left(\mathrm{C}_{6} \mathrm{~F}_{5}\right)_{2}\left(\mathrm{C}_{10} \mathrm{H}_{7} \mathrm{CN}\right)_{2}\right) \mathrm{Ag}\right]^{+}, 801\left[\mathrm{Pt}\left(\mathrm{C}_{13} \mathrm{H}_{8} \mathrm{~N}\right)\left(\mathrm{C}_{6} \mathrm{~F}_{5}\right)\left(\mathrm{C}_{10} \mathrm{H}_{7} \mathrm{CN}\right) \mathrm{Ag}\right]^{+}$, $679\left[\mathrm{Pt}\left(\mathrm{C}_{13} \mathrm{H}_{8} \mathrm{~N}\right)\left(\mathrm{C}_{10} \mathrm{H}_{7} \mathrm{CN}\right)_{2}\right], 526\left[\mathrm{Pt}\left(\mathrm{C}_{13} \mathrm{H}_{8} \mathrm{~N}\right)\left(\mathrm{C}_{10} \mathrm{H}_{7} \mathrm{CN}\right)\right]^{+}$.

Preparation of $\left[\left\{\mathrm{Pt}\left(\mathrm{C}_{6} \mathrm{~F}_{5}\right)(\mathbf{b z q})\left(\mathrm{CN}-2,6-\mathrm{Me}_{2} \mathrm{Ph}\right) \mathrm{Ag}_{2}\right]\left(\mathrm{ClO}_{4}\right)_{2}\right.$ (6). To a solution of [Pt(bzq) $\left.\left(\mathrm{C}_{6} \mathrm{~F}_{5}\right)\left(\mathrm{CN}-2,6-\mathrm{Me}_{2} \mathrm{Ph}\right)\right](0.120 \mathrm{~g}, 0.193 \mathrm{mmol})$ in $\mathrm{Me}_{2} \mathrm{CO}(60 \mathrm{~mL})$ at $0^{\circ} \mathrm{C}$ and under Ar atmosphere, $\mathrm{AgClO}_{4}(0.040 \mathrm{~g}, 0.193 \mathrm{mmol})$ was added. After $30 \mathrm{~min}$ of stirring in absence of light the solution was concentrated until ca. $2 \mathrm{~mL}$. Over the resultant yellow suspension, $n$-hexane $(10 \mathrm{~mL})$ was added. The yellow precipitate was filtered off and air dried. 0.252 g, 80.3\% yield. Anal. Found (calcd for $\mathrm{C}_{56} \mathrm{H}_{34} \mathrm{Ag}_{2} \mathrm{Cl}_{2} \mathrm{~F}_{10} \mathrm{~N}_{4} \mathrm{O}_{8} \mathrm{Pt}_{2}$ ): C, 38.09 (38.27); H, 2.00 (1.95); N, 3.21 (3.19). IR $\left(\mathrm{cm}^{-1}\right)$ : $2182\left(\mathrm{~m}, v_{\mathrm{NC}}\right), 1507$ (m), 1457 (m), 1445 (m), 1106 (m, $\left.v_{\mathrm{ClO} 4}{ }^{-}\right), 1061$ (s), 955 (s), 800 
(m, $\mathrm{C}_{6} \mathrm{~F}_{5}, \mathrm{X}$-sensitive vibr.) ${ }^{88}, 622\left(\mathrm{~m}, \mathrm{v}_{\mathrm{ClO} 4}{ }^{-}\right) . \Lambda_{\mathrm{M}}$ (acetone) $=346.31 \Omega^{-1} \mathrm{~cm}^{2} \mathrm{~mol}^{-1} .{ }^{1} \mathrm{H}$ NMR $\left(\mathrm{CD}_{2} \mathrm{Cl}_{2}, 298 \mathrm{~K}\right): \delta 9.20\left(2 \mathrm{H}, \mathrm{dd},{ }^{3} J_{\mathrm{H} 2-\mathrm{H} 3}=5.2 \mathrm{~Hz},{ }^{4} J_{\mathrm{H} 2-\mathrm{H} 4}=1.4 \mathrm{~Hz},{ }^{3} J_{\mathrm{H} 2-\mathrm{Pt}}=26.3\right.$ $\mathrm{Hz}, \mathrm{H} 2), 8.53\left(2 \mathrm{H}, \mathrm{dd},{ }^{3} J_{\mathrm{H} 4-\mathrm{H} 3}=8.1 \mathrm{~Hz},{ }^{4} J_{\mathrm{H} 4-\mathrm{H} 2}=1.4 \mathrm{~Hz}, \mathrm{H} 4\right), 7.83\left(2 \mathrm{H}, \mathrm{d},{ }^{3} J_{\mathrm{H} 5-\mathrm{H} 6}=8.7\right.$ $\mathrm{Hz}, \mathrm{H} 5), 7.68\left(2 \mathrm{H}, \mathrm{d},{ }^{3} J_{\mathrm{H} 6-\mathrm{H} 5}=8.7 \mathrm{~Hz}, \mathrm{H} 6\right), 7.64\left(2 \mathrm{H}, \mathrm{dd},{ }^{3} J_{\mathrm{H} 7-\mathrm{H} 8}=7.9 \mathrm{~Hz},{ }^{4} J_{\mathrm{H} 7-\mathrm{H} 9}=0.9\right.$ $\mathrm{Hz}, \mathrm{H} 7), 7.63\left(2 \mathrm{H}, \mathrm{d},{ }^{3} J_{\mathrm{H} 3-\mathrm{H} 4}=8.1 \mathrm{~Hz}, \mathrm{H} 3\right) 7.42\left(2 \mathrm{H}, \mathrm{dd},{ }^{3} J_{\mathrm{H} 8-\mathrm{H} 9}={ }^{3} J_{\mathrm{H} 8-\mathrm{H} 7}=7.5 \mathrm{~Hz}, \mathrm{H} 8\right)$, $7.31\left(2 \mathrm{H}, \mathrm{t},{ }^{3} J_{\mathrm{H} 3-\mathrm{H} 2}={ }^{3} J_{\mathrm{H} 3-\mathrm{H} 2^{\prime}}=7.5 \mathrm{~Hz}, \mathrm{CN}-2,6-\mathrm{Me}_{2} \mathrm{Ph}-\mathrm{H} 3\right), 7.18\left(4 \mathrm{H}, \mathrm{dd},{ }^{3} J_{\mathrm{H} 2-\mathrm{H} 3}=7.6\right.$ $\mathrm{Hz},{ }^{4} J_{\mathrm{H} 2-\mathrm{H} 2}=0.6 \mathrm{~Hz}, \mathrm{CN}-2,6-\mathrm{Me}_{2} \mathrm{Ph}-\mathrm{H} 2$ and H2'), $7.04\left(2 \mathrm{H}, \mathrm{dd},{ }^{3} J_{\mathrm{H} 9-\mathrm{H} 8}=7.5 \mathrm{~Hz},{ }^{3} J_{\mathrm{H} 9}\right.$ $\left.\mathrm{H} 7=0.9 \mathrm{~Hz},{ }^{3} J_{\mathrm{H} 9-\mathrm{Pt}}=50.2 \mathrm{~Hz}, \mathrm{H} 9\right), 2.40$ (6H, s, CN-2,6-Me $\mathrm{Ph}^{\left.-\mathrm{CH}_{3}\right) .}{ }^{19} \mathrm{~F} \mathrm{NMR}$ (Acetone- $\left.\mathrm{d}_{6}, 298 \mathrm{~K}\right): \delta-117.44\left(2 \mathrm{o}-\mathrm{F}, \mathrm{m},{ }^{3} J_{\mathrm{F}-\mathrm{Pt}}=454.8 \mathrm{~Hz}\right), 163.56(p-\mathrm{F}, \mathrm{t}),-165.12$ (2m-F, br m).

Preparation of $\left[\left(\mathrm{C}_{6} \mathrm{~F}_{5}\right)(\mathrm{bzq})(\mathrm{CNR}) \mathrm{PtAg}\left(\mathrm{PPh}_{3}\right)\right] \mathrm{ClO}_{4}\left\{\mathrm{R}={ }^{t} \mathrm{Bu},(7)\right.$, 2-naphthyl (8), 2,6- $\mathrm{Me}_{2} \mathrm{Ph}(9)$.

To a solution of $\left[\mathrm{Pt}(\mathrm{bzq})\left(\mathrm{C}_{6} \mathrm{~F}_{5}\right)(\mathrm{CNR})\right]\left(\mathrm{R}={ }^{t} \mathrm{Bu}, 0.150 \mathrm{~g}, 0.240 \mathrm{mmol} ; \mathrm{R}=\right.$ 2-naphtyl, 0.015 g, 0.216 mmol; $\mathrm{R}=2,6-\mathrm{Me}_{2} \mathrm{Ph}, 0.015 \mathrm{~g}, 0.223 \mathrm{mmol}$ ) in $\mathrm{CH}_{2} \mathrm{Cl}_{2}$ (30 mL) at $0^{\circ} \mathrm{C}$ and under $\mathrm{Ar}$ atmosphere, $\mathrm{AgOClO}_{3} \mathrm{PPh}_{3}\left(\mathrm{R}={ }^{t} \mathrm{Bu}, 0.112 \mathrm{~g}, 0.240 \mathrm{mmol} ; \mathrm{R}=\right.$ 2-naphtyl, $0.101 \mathrm{~g}, 0.216 \mathrm{mmol} ; \mathrm{R}=2,6-\mathrm{Me}_{2} \mathrm{Ph}, 0.104 \mathrm{~g}, 0.223 \mathrm{mmol}$ ) was added. After $30 \mathrm{~min}$ of stirring in absence of light the solution was concentrated until ca. $2 \mathrm{~mL}$. Over the resultant yellow suspension, $n$-hexane $(10 \mathrm{~mL})$ was added. The yellow precipitate was filtered off and air dried.

$\left[\left(\mathbf{C}_{6} \mathbf{F}_{5}\right)(\mathbf{b z q})\left(\mathbf{C N}^{t} \mathrm{Bu}\right) \mathbf{P t A g}\left(\mathbf{P P h}_{3}\right)\right] \mathrm{ClO}_{4}$ (7). 0.231 g, 87.8\%. Anal. Found (calcd for $\mathrm{C}_{42} \mathrm{H}_{32} \mathrm{AgClF}_{5} \mathrm{~N}_{2} \mathrm{O}_{4} \mathrm{PPt}$ ): C, 46.11 (46.15); H, 2.89 (2.95); N, 2.83 (2.56). IR ( $\left.\mathrm{cm}^{-1}\right)$ : $2196\left(\mathrm{~m}, \mathrm{v}_{\mathrm{NC}}\right), 1500(\mathrm{~m}), 1456$ (m), 1436 (m), 1094 (m, v $\left.\mathrm{ClO}^{-}\right), 1058$ (s, $\left.v_{\mathrm{PPh} 3}\right), 954$ (s), 799 (m, $\mathrm{C}_{6} \mathrm{~F}_{5}, \mathrm{X}$-sensitive vibr. $)^{88}, 691$ (s, v $\left.v_{\mathrm{PPh} 3}\right), 620$ (w, $\left.v_{\mathrm{ClO} 4}{ }^{-}\right), 519$ (m, v $\left.v_{\mathrm{PPh} 3}\right), 503$ (m, vPPh3). $\Lambda_{\mathrm{M}}$ (acetone) $=206.72 \Omega^{-1} \mathrm{~cm}^{2} \mathrm{~mol}^{-1} .{ }^{1} \mathrm{H}$ NMR (Acetone-d $\left.\mathrm{d}_{6}, 298 \mathrm{~K}\right): \delta 9.24(1 \mathrm{H}$, $\left.\mathrm{dd},{ }^{3} J_{\mathrm{H} 2-\mathrm{H} 3}=5.2 \mathrm{~Hz},{ }^{4} J_{\mathrm{H} 2-\mathrm{H} 4}=1.3 \mathrm{~Hz},{ }^{3} J_{\mathrm{H} 2-\mathrm{Pt}}=26.4 \mathrm{~Hz}, \mathrm{H} 2\right), 8.74\left(1 \mathrm{H}, \mathrm{dd},{ }^{3} J_{\mathrm{H} 4-\mathrm{H} 3}=8.1\right.$ $\left.\mathrm{Hz},{ }^{4} J_{\mathrm{H} 4-\mathrm{H} 2}=1.3 \mathrm{~Hz}, \mathrm{H} 4\right), 7.94\left(1 \mathrm{H}, \mathrm{d},{ }^{3} J_{\mathrm{H} 5-\mathrm{H} 6}=8.8 \mathrm{~Hz}, \mathrm{H} 5\right), 7.83\left(1 \mathrm{H}, \mathrm{d},{ }^{3} J_{\mathrm{H} 6-\mathrm{H} 5}=8.8\right.$ $\mathrm{Hz}, \mathrm{H} 6), 7.81\left(1 \mathrm{H}, \mathrm{dd},{ }^{3} J_{\mathrm{H} 3-\mathrm{H} 4}=8.1 \mathrm{~Hz},{ }^{3} J_{\mathrm{H} 3-\mathrm{H} 2}=5.2 \mathrm{~Hz}, \mathrm{H} 3\right), 7.75\left(1 \mathrm{H}, \mathrm{dd},{ }^{3} J_{\mathrm{H} 7-\mathrm{H} 8}=\right.$ $\left.8.0 \mathrm{~Hz},{ }^{4} J_{\mathrm{H} 7-\mathrm{H} 9}=0.9 \mathrm{~Hz}, \mathrm{H} 7\right), 7.61(16 \mathrm{H}, \mathrm{m}, \mathrm{H} 8$ and 15H-Ph overlapped), $7.18(1 \mathrm{H}, \mathrm{d}$, $\left.{ }^{3} J_{\mathrm{H} 9-\mathrm{H} 8}=7.0 \mathrm{~Hz},{ }^{3} J_{\mathrm{H} 2-\mathrm{Pt}}=47.7 \mathrm{~Hz}, \mathrm{H} 9\right), 1.64\left(9 \mathrm{H}, \mathrm{s}, \mathrm{CN}^{t} \mathrm{Bu}_{-} \mathrm{CH}_{3}\right) .{ }^{19} \mathrm{~F}$ NMR (Acetone$\left.\mathrm{d}_{6}, 298 \mathrm{~K}\right): \delta-117.48\left(2 o-\mathrm{F},{ }^{3} J_{\mathrm{F}-\mathrm{Pt}}=460.2 \mathrm{~Hz}\right), 165.91(p-\mathrm{F}, \mathrm{t}),-167.34(2 m-\mathrm{F}, \mathrm{br} \mathrm{m})$. ${ }^{31} \mathrm{P}$ NMR (Acetone-d $\left.\mathrm{d}_{6}, 298 \mathrm{~K}\right): \delta 13.74\left(\mathrm{~d}, J_{\mathrm{P}-\mathrm{Ag}}=693.3 \mathrm{~Hz}\right)$. Mass spectra MALDI+

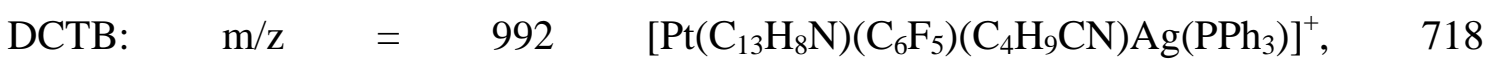


$\left[\mathrm{Pt}\left(\mathrm{C}_{13} \mathrm{H}_{8} \mathrm{~N}\right)\left(\mathrm{C}_{4} \mathrm{H}_{9} \mathrm{CN}\right)\left(\mathrm{PPh}_{3}\right)\right]^{+}$,

662

$\left[\mathrm{Pt}\left(\mathrm{C}_{13} \mathrm{H}_{8} \mathrm{~N}\right)(\mathrm{CNH})\left(\mathrm{PPh}_{3}\right)\right]^{+}$,

635 $\left[\mathrm{Pt}\left(\mathrm{C}_{13} \mathrm{H}_{8} \mathrm{~N}\right)\left(\mathrm{PPh}_{3}\right)\right]^{2+}, 400\left[\mathrm{Pt}\left(\mathrm{C}_{13} \mathrm{H}_{8} \mathrm{~N}\right)(\mathrm{CNH})\right]^{+}$.

[(C $\left.\left.\mathbf{C}_{6} \mathbf{F}_{5}\right)(\mathbf{b z q})(\mathbf{C N}-2-n a p h t y l) P t A g\left(\mathbf{P P h}_{3}\right)\right] \mathbf{C l O}_{4}$ (8). 0.184 g, 73.2\% yield. Anal. Found (calcd for $\mathrm{C}_{48} \mathrm{H}_{30} \mathrm{AgClF}_{5} \mathrm{~N}_{2} \mathrm{O}_{4} \mathrm{PPt}$ ): C, 49.63 (49.57); H, 2.52 (2.60); N, 2.55 (2.41). IR $\left(\mathrm{cm}^{-1}\right): 2177\left(\mathrm{~m}, \mathrm{v}_{\mathrm{NC}}\right), 1503(\mathrm{~m}), 1459(\mathrm{~m}), 1447(\mathrm{~m}), 1094$ (w, $\left.v_{\mathrm{ClO} 4}{ }^{-}\right), 1060$ (s, $\left.v_{\mathrm{PPh} 3}\right)$, 957 (s), 801 (m, $\mathrm{C}_{6} \mathrm{~F}_{5}, \mathrm{X}$-sensitive vibr. $)^{88}, 691$ (s, $\left.v_{\mathrm{PPh} 3}\right), 621$ (m, $\left.v_{\mathrm{ClO} 4}{ }^{-}\right), 517$ (m, $v_{\mathrm{PPh} 3}$ ), $503\left(\mathrm{~m}, v_{\mathrm{PPh} 3}\right) \cdot \Lambda_{\mathrm{M}}$ (acetone) $=206.28 \Omega^{-1} \mathrm{~cm}^{2} \mathrm{~mol}^{-1} \cdot{ }^{1} \mathrm{H}$ NMR (Acetone- $\left.\mathrm{d}_{6}, 298 \mathrm{~K}\right): \delta$ $9.56\left(1 \mathrm{H}, \mathrm{dd},{ }^{3} J_{\mathrm{H} 2-\mathrm{H} 3}=5.1 \mathrm{~Hz},{ }^{4} J_{\mathrm{H} 2-\mathrm{H} 4}=1.3 \mathrm{~Hz},{ }^{3} J_{\mathrm{H} 2-\mathrm{Pt}}=25.5 \mathrm{~Hz}, \mathrm{H} 2\right), 8.78(1 \mathrm{H}, \mathrm{dd}$, $\left.{ }^{3} J_{\mathrm{H} 4-\mathrm{H} 3}=8.1 \mathrm{~Hz},{ }^{4} J_{\mathrm{H} 4-\mathrm{H} 2}=1.3 \mathrm{~Hz}, \mathrm{H} 4\right), 8.38\left(1 \mathrm{H}, \mathrm{d},{ }^{3} J_{\mathrm{H} 1-\mathrm{H} 3}=2.0 \mathrm{~Hz}, \mathrm{CN}-2-\right.$ naphthyl$\mathrm{H} 1), 8.14\left(1 \mathrm{H}, \mathrm{d},{ }^{3} J_{\mathrm{H} 4-\mathrm{H} 3}=8.8 \mathrm{~Hz}, \mathrm{CN}-2-n a p h t h y l-H 4\right), 8.09-8.05$ (2H, m, CN-2naphthyl-H6 and H7) $7.96\left(1 \mathrm{H}, \mathrm{d},{ }^{3} J_{\mathrm{H} 5-\mathrm{H} 6}=8.7 \mathrm{~Hz}, \mathrm{H} 5\right), 7.84\left(1 \mathrm{H}, \mathrm{d},{ }^{3} J_{\mathrm{H} 6-\mathrm{H} 5}=8.7 \mathrm{~Hz}\right.$, H6, $7.83\left(1 \mathrm{H}, \mathrm{dd},{ }^{3} J_{\mathrm{H} 3-\mathrm{H} 4}=8.1 \mathrm{~Hz},{ }^{3} J_{\mathrm{H} 3-\mathrm{H} 2}=5.2 \mathrm{~Hz}, \mathrm{H} 3\right), 7.77\left(1 \mathrm{H}, \mathrm{d},{ }^{3} J_{\mathrm{H} 3-\mathrm{H} 4}=8.8 \mathrm{~Hz}\right.$, ${ }^{4} J_{\mathrm{H} 3-\mathrm{H} 1}=2.0 \mathrm{~Hz}, \mathrm{CN}-2-$ naphthyl-H3), 7.74-7.68 (3H, m, bzq-H7 overlapped with CN-2naphthyl-H5 and CN-2-naphthyl-H8), 7.60-7.54 (15H, m, 15H-Ph), 7.51 (1H, dd, ${ }^{3} J_{\mathrm{H} 8}$ н9 $\left.={ }^{3} J_{\mathrm{H} 8-\mathrm{H} 7}=7.9 \mathrm{~Hz}, \mathrm{H} 8\right), 7.16\left(1 \mathrm{H}, \mathrm{d},{ }^{3} J_{\mathrm{H} 9-\mathrm{H} 8}=7.9 \mathrm{~Hz},{ }^{3} J_{\mathrm{Pt}-\mathrm{H} 9}=49.0 \mathrm{~Hz}, \mathrm{H} 9\right) .{ }^{19} \mathrm{~F}$ NMR (Acetone- $\left.\mathrm{d}_{6}, 298 \mathrm{~K}\right): \delta-118.03\left(2 o-\mathrm{F},{ }^{3} J_{\mathrm{F}-\mathrm{Pt}}=464.0 \mathrm{~Hz}\right), 166.00(p-\mathrm{F}$, t), -167.31 (2m-F, br m). ${ }^{31} \mathrm{P}$ NMR (Acetone-d $\left.\mathrm{d}_{6}, 298 \mathrm{~K}\right), \delta 13.3\left(\mathrm{~d}, J_{\mathrm{P}-\mathrm{Ag}}=664.1 \mathrm{~Hz}\right.$ ). Mass spectra MALDI+ DCTB: $\mathrm{m} / \mathrm{z}=1063\left[\mathrm{Pt}\left(\mathrm{C}_{13} \mathrm{H}_{8} \mathrm{~N}\right)\left(\mathrm{C}_{6} \mathrm{~F}_{5}\right)\left(\mathrm{C}_{10} \mathrm{H}_{7} \mathrm{CN}\right) \mathrm{Ag}\left(\mathrm{PPh}_{3}\right)\right]^{+}$, $788 \quad\left[\mathrm{Pt}\left(\mathrm{C}_{13} \mathrm{H}_{8} \mathrm{~N}\right)\left(\mathrm{C}_{10} \mathrm{H}_{7} \mathrm{CN}\right)\left(\mathrm{PPh}_{3}\right)\right]^{+}, \quad 679 \quad\left[\mathrm{Pt}\left(\mathrm{C}_{13} \mathrm{H}_{8} \mathrm{~N}\right)\left(\mathrm{C}_{10} \mathrm{H}_{7} \mathrm{~N}\right)_{2}\right], \quad 635$ $\left[\mathrm{Pt}\left(\mathrm{C}_{13} \mathrm{H}_{8} \mathrm{~N}\right)\left(\mathrm{PPh}_{3}\right)\right]^{2+}, 526\left[\mathrm{Pt}\left(\mathrm{C}_{13} \mathrm{H}_{8} \mathrm{~N}\right)\left(\mathrm{C}_{10} \mathrm{H}_{7} \mathrm{CN}\right)\right]^{+}$

[( $\left.\left.\mathbf{C}_{6} \mathbf{F}_{5}\right)(\mathbf{b z q})\left(\mathbf{C N}-2,6-\mathrm{Me}_{2} \mathbf{P h}\right) \mathbf{P t A g}\left(\mathbf{P P h}_{3}\right)\right] \mathrm{ClO}_{4}$ (9). 0.220 g, 86.5\% yield. Anal. Found (calcd for $\mathrm{C}_{46} \mathrm{H}_{32} \mathrm{AgClF}_{5} \mathrm{~N}_{2} \mathrm{O}_{4} \mathrm{PPt}$ ): C, 48.52 (48.42); H, 2.82 (2.83); N, 2.62 (2.45). IR $\left(\mathrm{cm}^{-1}\right): 2164\left(\mathrm{~m}, \mathrm{v}_{\mathrm{NC}}\right), 1503(\mathrm{~m}), 1459(\mathrm{~m}), 1436(\mathrm{~m}), 1098$ (m, $\left.\mathrm{v}_{\mathrm{ClO} 4}{ }^{-}\right), 1060$ (s, $\left.v_{\mathrm{PPh} 3}\right)$, 957 (s), 801 (m, $\mathrm{C}_{6} \mathrm{~F}_{5}, \mathrm{X}$-sensitive vibr. $)^{88}, 692$ (s, $\left.v_{\mathrm{PPh} 3}\right), 621$ (m, $\left.v_{\mathrm{ClO} 4}{ }^{-}\right), 520$ (s, $\left.v_{\mathrm{PPh} 3}\right)$. $\Lambda_{\mathrm{M}}$ (acetone) $=214.80 \Omega^{-1} \mathrm{~cm}^{2} \mathrm{~mol}^{-1} .{ }^{1} \mathrm{H} \mathrm{NMR}$ (Acetone- $\left.\mathrm{d}_{6}, 298 \mathrm{~K}\right): \delta 9.50\left(1 \mathrm{H}, \mathrm{dd},{ }^{3} J_{\mathrm{H} 2}\right.$ $\left.\mathrm{H} 3=5.2 \mathrm{~Hz},{ }^{4} J_{\mathrm{H} 2-\mathrm{H} 4}=1.3 \mathrm{~Hz},{ }^{3} J_{\mathrm{H} 2-\mathrm{Pt}}=25.6 \mathrm{~Hz}, \mathrm{H} 2\right), 8.77\left(1 \mathrm{H}, \mathrm{dd},{ }^{3} J_{\mathrm{H} 4-\mathrm{H} 3}=8.1 \mathrm{~Hz},{ }^{4} J_{\mathrm{H} 4-}\right.$ $\mathrm{H} 2=1.3 \mathrm{~Hz}, \mathrm{H} 4), 7.95\left(1 \mathrm{H}, \mathrm{d},{ }^{3} J_{\mathrm{H} 5-\mathrm{H} 6}=8.8 \mathrm{~Hz}, \mathrm{H} 5\right), 7.83\left(1 \mathrm{H}, \mathrm{dd},{ }^{3} J_{\mathrm{H} 3-\mathrm{H} 4}=8.1 \mathrm{~Hz},{ }^{3} J_{\mathrm{H} 3}\right.$ $\mathrm{H} 2=5.2 \mathrm{~Hz}, \mathrm{H} 3), 7.82\left(1 \mathrm{H}, \mathrm{d},{ }^{3} J_{\mathrm{H} 6-\mathrm{H} 5}=8.8 \mathrm{~Hz}, \mathrm{H} 6\right), 7.72\left(1 \mathrm{H}, \mathrm{dd},{ }^{3} J_{\mathrm{H} 7-\mathrm{H} 8}=8.0 \mathrm{~Hz},{ }^{4} J_{\mathrm{H} 7-}\right.$ н9 $=0.8 \mathrm{~Hz}, \mathrm{H} 7), 7.62-7.48\left(16 \mathrm{H}, \mathrm{m}, \mathrm{H} 8\right.$ and 15H-Ph overlapped), $7.38\left(1 \mathrm{H}, \mathrm{dd},{ }^{3} J_{\mathrm{H} 3-\mathrm{H} 2}\right.$ $\left.={ }^{3} J_{\mathrm{H} 3-\mathrm{H} 2^{\prime}}=8.2 \mathrm{~Hz},{ }^{3} J_{\mathrm{H} 2-\mathrm{H} 2^{\prime}}=0.5 \mathrm{~Hz}, \mathrm{CN}-2,6-\mathrm{Me}_{2} \mathrm{Ph}-\mathrm{H} 3\right), 7.28\left(2 \mathrm{H}, \mathrm{dd},{ }^{3} J_{\mathrm{H} 2-\mathrm{H} 3}={ }^{3} J_{\mathrm{H}^{\prime}-}\right.$ ${ }_{\mathrm{H} 3}=8.2 \mathrm{~Hz},{ }^{4} J_{\mathrm{H} 2-\mathrm{H} 2^{\prime}}=0.6 \mathrm{~Hz}, \mathrm{CN}-2,6-\mathrm{Me}_{2} \mathrm{Ph}-\mathrm{H} 2$ and $\left.\mathrm{H} 2^{\prime}\right), 7.15\left(1 \mathrm{H}, \mathrm{d},{ }^{3} J_{\mathrm{H} 9-\mathrm{H} 8}=7.0\right.$ $\left.\mathrm{Hz},{ }^{3} J_{\mathrm{H} 9-\mathrm{Pt}}=50.1 \mathrm{~Hz}, \mathrm{H} 9\right), 2.43\left(6 \mathrm{H}, \mathrm{s}, \mathrm{CN}-2,6-\mathrm{Me}_{2} \mathrm{Ph}_{-} \mathrm{CH}_{3}\right) .{ }^{19} \mathrm{~F}$ NMR (Acetone-d $\mathrm{d}_{6}$, $298 \mathrm{~K}): \delta-118.03\left(2 o-\mathrm{F}, \mathrm{m},{ }^{3} J_{\mathrm{F}-\mathrm{Pt}}=469.3 \mathrm{~Hz}\right), 166.06$ (p-F, t), -167.44 (2m-F, br m). 
${ }^{31} \mathrm{P}$ NMR (Acetone-d 6 , $\left.298 \mathrm{~K}\right): \delta 13.34\left(\mathrm{~d}, J_{\mathrm{P}-\mathrm{Ag}}=713.4 \mathrm{~Hz}\right.$ ). Mass spectra MALDI+

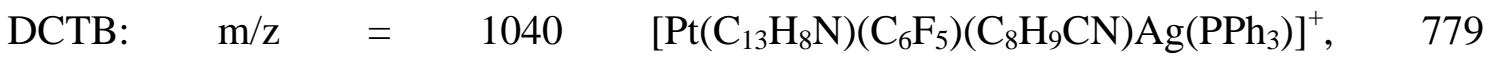
$\left[\mathrm{Pt}\left(\mathrm{C}_{13} \mathrm{H}_{8} \mathrm{~N}\right)\left(\mathrm{C}_{6} \mathrm{~F}_{5}\right)\left(\mathrm{C}_{8} \mathrm{H}_{9} \mathrm{CN}\right) \mathrm{Ag}\right]^{+}, \quad 662 \quad\left[\mathrm{Pt}\left(\mathrm{C}_{13} \mathrm{H}_{8} \mathrm{~N}\right)(\mathrm{CNH})\left(\mathrm{PPh}_{3}\right)\right]^{+}, \quad 635$ $\left[\mathrm{Pt}\left(\mathrm{C}_{13} \mathrm{H}_{8} \mathrm{~N}\right)\left(\mathrm{PPh}_{3}\right)\right]^{2+}, 504\left[\mathrm{Pt}\left(\mathrm{C}_{13} \mathrm{H}_{8} \mathrm{~N}\right)\left(\mathrm{C}_{8} \mathrm{H}_{9} \mathrm{CN}\right)\right]^{+}, 373\left[\mathrm{Pt}\left(\mathrm{C}_{13} \mathrm{H}_{8} \mathrm{~N}\right)\right]^{2+}$.

\section{3. $X$-ray structure determinations.}

Crystal data and other details of the structure analyses are presented in Tables 8 and 9. Suitable crystals for X-ray diffraction studies were obtained by slow diffusion of $n$-hexane into concentrated solutions of the complexes in $3 \mathrm{~mL}$ of $\mathrm{CH}_{2} \mathrm{Cl}_{2}$ or $\mathrm{Me}_{2} \mathrm{CO}$. Crystals were mounted at the end of quartz fibres. The radiation used in all cases was graphite monochromated $\operatorname{Mo}_{\mathrm{K} \alpha}(\lambda=0.71073 \AA)$. X-ray intensity data were collected on an Oxford Diffraction Xcalibur diffractometer. The diffraction frames were integrated and corrected from absorption by using the CrysAlis RED program. ${ }^{89}$ The structures were solved by Patterson and Fourier methods and refined by full-matrix least squares on $F^{2}$ with SHELXL-97. ${ }^{90}$ All non-hydrogen atoms were assigned anisotropic displacement parameters and refined without positional constraints, except as noted below. All hydrogen atoms were constrained to idealized geometries and assigned isotropic displacement parameters equal to 1.2 times the $U_{\text {iso }}$ values of their attached parent atoms (1.5 times for the methyl hydrogen atoms). In the structure of $4 \mathbf{b} \cdot 0.3 \mathrm{Me}_{2} \mathrm{CO}$ one of the $\mathrm{CN}^{t} \mathrm{Bu}$ ligands has its nitrogen atom and ${ }^{t} \mathrm{Bu}$ group disordered over two positions which were refined with 0.5/0.5 partial occupancy. Very diffuse solvent was found during the refinement process, but only one molecule of acetone with low occupancy (0.3) could be properly modelled. In order to deal with this unassigned electron density, the SQUEEZE procedure as implemented in the PLATON crystallographic program. ${ }^{91}$ For $5 \cdot 0.9 \mathrm{Me}_{2} \mathrm{CO}$ rOne of the naphtyl groups of the isonitrile is disordered and the positions of both sets of atoms were refined with partial occupancy 0.5. The oxygen atoms of the perchlorate anion are disordered over two sets of positions refined with 0.5 partial occupancy. Restrains were used in the $\mathrm{Cl}-\mathrm{O}$ distances and in the anisotropic thermal parameters of the oxygen atoms. Two very diffuse acetone solvent molecules were found in the density maps. They were assigned 0.5 and 0.4 partial occupancy. Restrains in their geometry and anisotropic thermal parameter were applied.. Full-matrix least-squares refinement of these models against $F^{2}$ converged to final residual indices given in Tables 6 and 7. 
Table 6. Crystal data and structure refinement for complexes $\left[\mathrm{Pt}\left(\mathrm{C}_{6} \mathrm{~F}_{5}\right)(\mathrm{bzq})\left(\mathrm{CN}^{t} \mathrm{Bu}\right)\right]$ (1) and $\left[\mathrm{Pt}\left(\mathrm{C}_{6} \mathrm{~F}_{5}\right)(\mathrm{bzq})\left(\mathrm{CN}-2,6-\mathrm{Me}_{2} \mathrm{Ph}\right)\right] \cdot 0.5 n-\mathrm{C}_{6} \mathrm{H}_{14}\left(3 \cdot 0.5 n-\mathrm{C}_{6} \mathrm{H}_{14}\right)$.

\begin{tabular}{|c|c|c|}
\hline & 1 & $3 \cdot 0.5 n-\mathrm{C}_{6} \mathrm{H}_{14}$ \\
\hline \multirow[t]{2}{*}{ Formula } & $\mathrm{C}_{24} \mathrm{H}_{17} \mathrm{~F}_{5} \mathrm{~N}_{2} \mathrm{Pt}$ & $\mathrm{C}_{28} \mathrm{H}_{17} \mathrm{~F}_{5} \mathrm{~N}_{2} \mathrm{Pt}$ \\
\hline & & $\cdot 0.5 n-\mathrm{C}_{6} \mathrm{H}_{14}$ \\
\hline$M_{t}$ & 623.49 & 714.61 \\
\hline Crystal system & orthorhombic & triclinic \\
\hline Space group & $F d d 2$ & $P-1$ \\
\hline$a / \AA$ & 33.1904(17) & $8.4782(4)$ \\
\hline$b / \AA$ & 37.5532(16) & 12.1683(5)) \\
\hline$c / \AA$ & $6.7182(2)$ & 13.8379(6) \\
\hline$a /^{\circ}$ & 90 & $69.009(4)$ \\
\hline$\beta /^{\circ}$ & 90 & $74.847(4)$ \\
\hline$\gamma / /^{\circ}$ & 90 & 87.969(3) \\
\hline$V / \AA^{3}$ & 8373.6(6) & 1283.82(10) \\
\hline$Z$ & 16 & 2 \\
\hline$D_{c} / \mathrm{g} \mathrm{cm}^{-3}$ & 1.978 & 1.849 \\
\hline$T / \mathrm{K}$ & $100(1)$ & $100(1)$ \\
\hline$\mu / \mathrm{mm}^{-1}$ & 6.761 & 5.525 \\
\hline$F(000)$ & 4768 & 694 \\
\hline $2 \theta$ range $/^{\circ}$ & $8.6-57.4$ & $8.5-57.6$ \\
\hline Collected reflections & 12705 & 9354 \\
\hline Unique reflections & 4665 & 5783 \\
\hline$R_{\text {int }}$ & 0.0264 & 0.0290 \\
\hline$R_{1}, w R_{2}^{a}(I>2 \sigma(I))$ & $0.0188,0.0392$ & $0.0316,0.0549$ \\
\hline$R_{1}, w R_{2}^{a}$ (all data) & $0.0207,0.0400$ & $0.0419,0.0563$ \\
\hline $\operatorname{GOF}\left(F^{2}\right)^{b}$ & 1.015 & 1.012 \\
\hline Absolute structure parameter & $-0.009(6)$ & - \\
\hline
\end{tabular}

${ }^{a} R_{1}=\sum\left(\left|F_{\mathrm{o}}\right|-\left|F_{\mathrm{C}}\right|\right) / \sum\left|F_{\mathrm{o}}\right| \cdot w R_{2}=\left[\sum \mathrm{w}\left(F_{\mathrm{o}}{ }^{2}-F_{\mathrm{c}}{ }^{2}\right)^{2} / \sum \mathrm{w}\left(F_{\mathrm{o}}{ }^{2}\right)^{2}\right]^{1 / 2} \cdot{ }^{b}$ Goodness-of-fit $=$ $\left[\sum \mathrm{w}\left(F_{\mathrm{o}}^{2}-F_{\mathrm{c}}^{2}\right)^{2} /\left(n_{\mathrm{obs}}-n_{\mathrm{param}}\right)\right]^{1 / 2}$. 
$F$

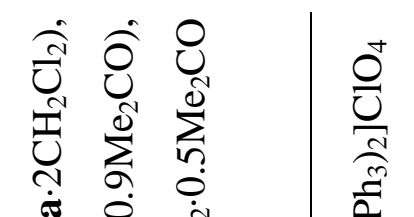

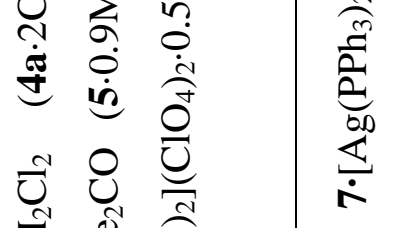

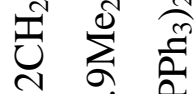

○े

花

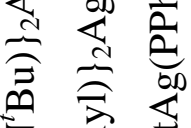

㞯 全言

눙

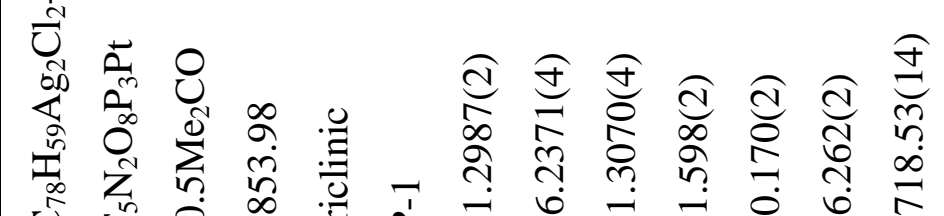

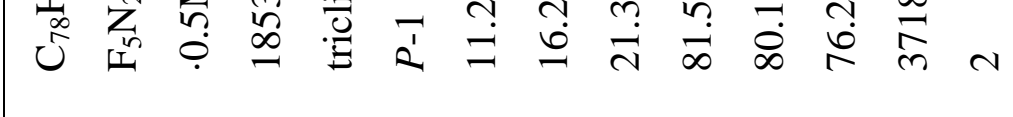

㲾

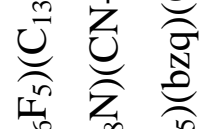

点

这

노

声

¿ $\hat{0}$

훙

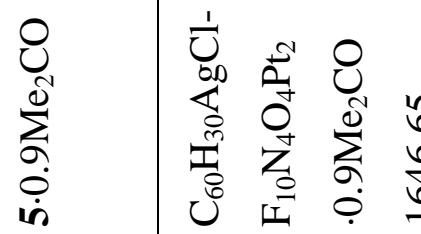

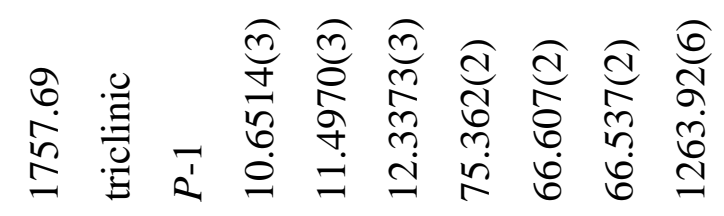

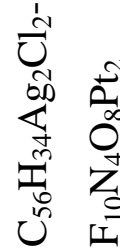

苞

巳

总

च

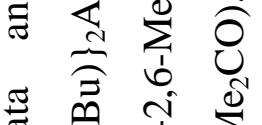

च

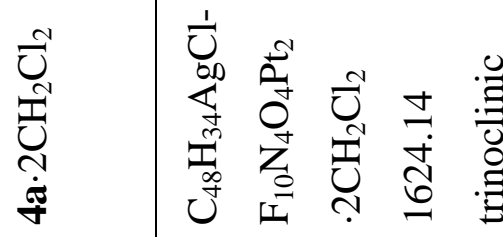

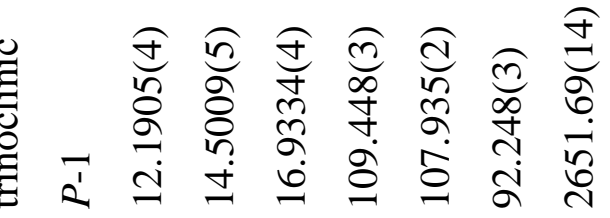

焉

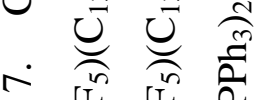

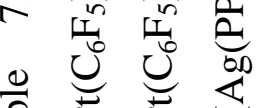

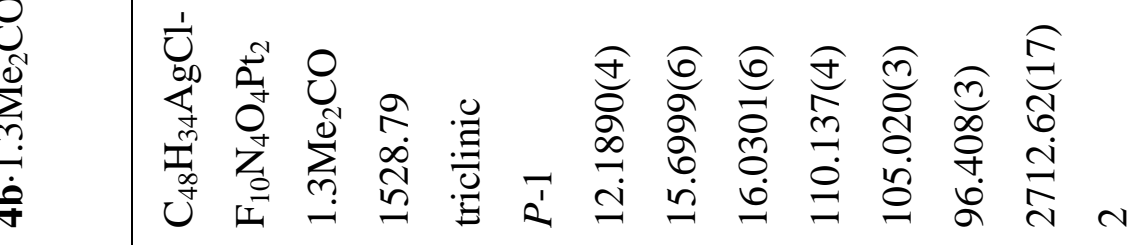

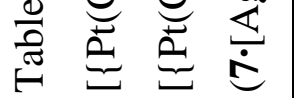

疍

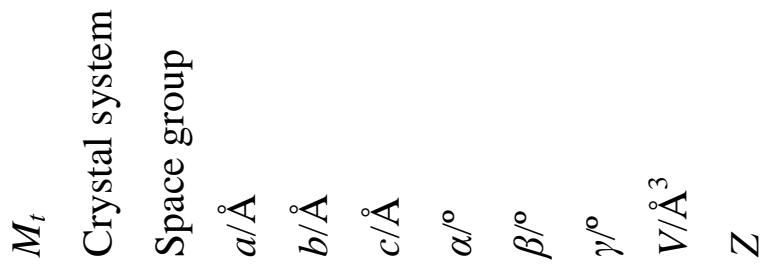


ร

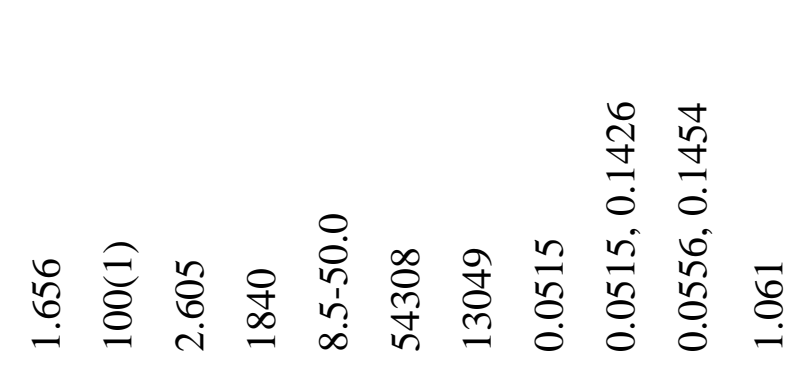

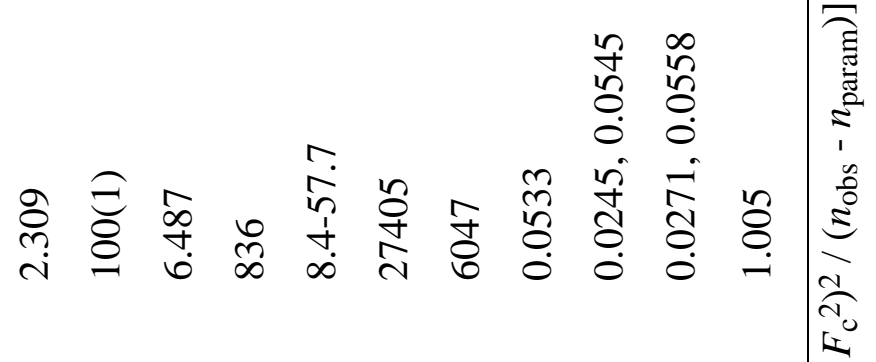

m

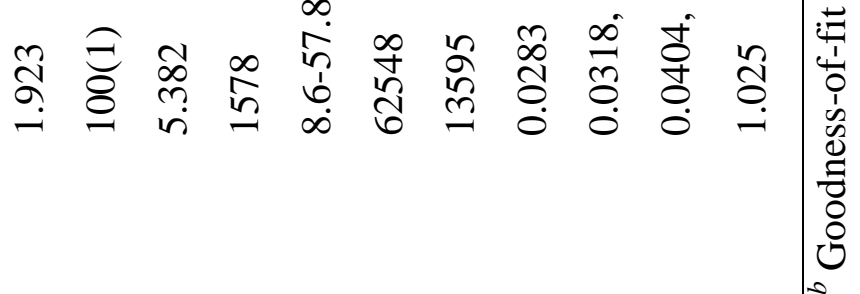

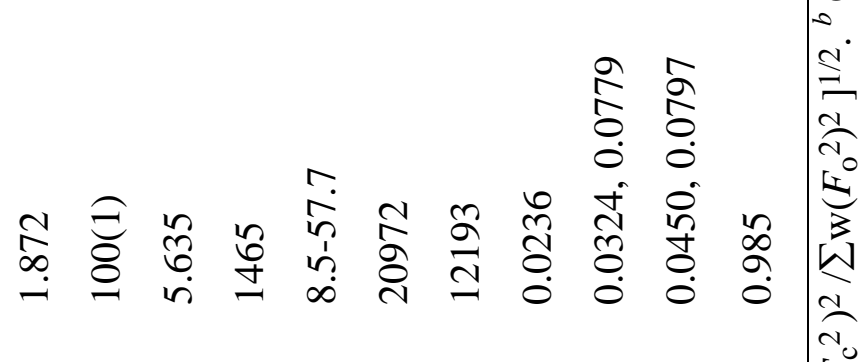

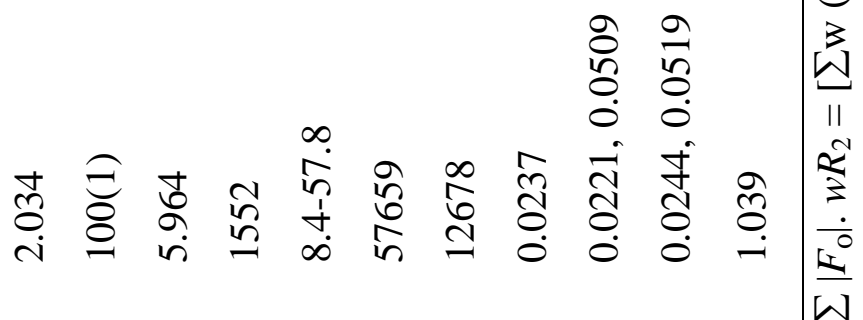

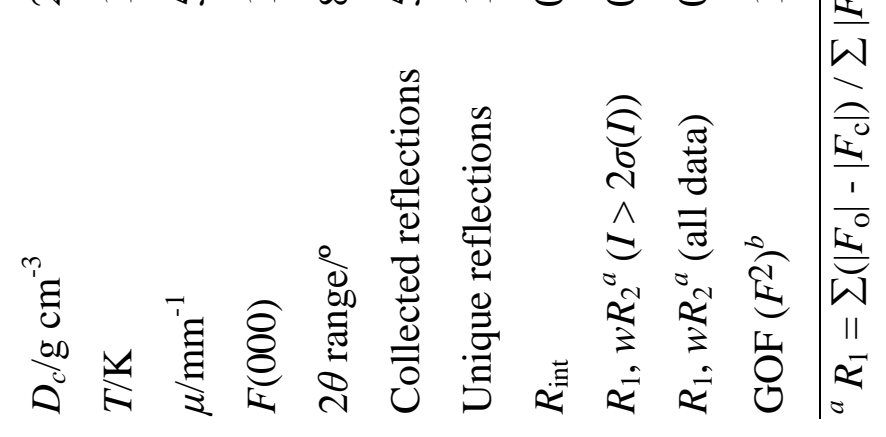




\subsection{Computational details.}

Quantum mechanical calculations were performed with the Gaussian09 package $^{92}$ at the DFT/M06 level of theory. ${ }^{93}$ SDD basis set and its corresponding effective core potentials were used to describe the platinum and silver atoms. ${ }^{94}$ An additional set of $\mathrm{f}$ type functions was also added for both elements. ${ }^{95}$ Carbon, fluorine, hydrogen, nitrogen and oxygen atoms were described with a 6-31G basis set. ${ }^{96,97}$ All the discussed structures were optimized in the gas phase, with no symmetry restrictions. The computed minima were subsequently characterized by analytically computing the Hessian matrix. TD-DFT calculations were performed on the optimized structures and in dichloromethane as solvent by using the polarizable continuum model (PCM) approach implemented in the Gaussian 09 software.

Acknowledgments. This work was supported by the Spanish MICINN (DGPTC/FEDER) (Project CTQ2008-06669-C02-01/BQU) and MINECO (Projects CTQ2012-35251 and TEC2012-38901-C02-01), and the Gobierno de Aragón (Grupo Consolidado E21: Química Inorgánica y de los Compuestos Organometálicos). The authors thank the Instituto de Biocomputación y Física de Sistemas Complejos (BIFI) and the Centro de Supercomputación de Galicia (CESGA) for generous allocation of computational resources.

\section{Appendix A. Supplementary material.}

CCDC 1002595-1002601 contain the supplementary crystallographic data for compounds $\mathbf{1}, \quad \mathbf{3} \cdot 0.5 n-\mathrm{C}_{6} \mathrm{H}_{14}, \quad \mathbf{4 a} \cdot 2 \mathrm{CH}_{2} \mathrm{Cl}_{2}, \quad \mathbf{4 b} \cdot 1.3 \mathrm{Me}_{2} \mathrm{CO}, \quad \mathbf{5} \cdot 0.9 \mathrm{Me}_{2} \mathrm{CO}, \quad \mathbf{6}$ and $7 \cdot\left[\mathrm{Ag}\left(\mathrm{PPh}_{3}\right)_{2}\right] \mathrm{ClO}_{4} \cdot 0.5 \mathrm{Me}_{2} \mathrm{CO}$ respectively. These data can be obtained free of charge from The Cambridge Crystallographic Data Centre via www.ccdc.cam.ac.uk/ data_request/cif. Supplementary data associated with this article can be found, in the online version, at http://dx.doi.org/XXXXXXX 


\section{References}

(1) Pyykkö, P. Chem. Rev. 1997, 97, 597-636.

(2) Pyykkö, P. Angew. Chem. Int. Ed. 2004, 43, 4412-4456.

(3) Gade, L. H. Angew. Chem. Int. Ed. 2001, 40, 3573-3575.

(4) Carvajal, M. A.; Álvarez, S.; Novoa, J. J. Chem, Eur. J. 2004, 10, 2117-2132.

(5) Díez, A.; Lalinde, E.; Moreno, M. T. Coord. Chem. Rev. 2011, 255, 2426-2447.

(6) Fernández, E. J.; Laguna, A.; López de Luzuriaga, J. M. Dalton Trans. 2007, 1969-1981.

(7) Fernández, E. J.; López de Luzuriaga, J. M.; Monge, M.; Rodríguez, M. A.; Crespo, O.; Gimeno, M. C.; Laguna, A.; Jones, P. G. Chem, Eur. J. 2000, 6, 636644.

(8) Yam, V. W. W.; Cheng, E. C. C. Chem. Soc. Rev. 2008, 37, 1806-1813.

(9) Schmidbaur, H.; Schier, A. Chem. Soc. Rev. 2008, 37, 1931-1951.

(10) Sculfort, S.; Braunstein, P. Chem. Soc. Rev. 2011, 40, 2741-2760.

(11) Fernández, E. J.; Laguna, A.; López de Luzuriaga, J. M. Coord. Chem. Rev. 2005, 249, 1423-1433.

(12) Moret, M.-E.; Chen, P. J. Am. Chem. Soc. 2009, 131, 5675-5690.

(13) Forniés, J.; Ibáñez, S.; Martín, A.; Sanz, M.; Berenguer, J. R.; Lalinde, E.; Torroba, J. Organometallics 2006, 25, 4331-4340.

(14) Forniés, J.; Ibáñez, S.; Martín, A.; Gil, B.; Lalinde, E.; Moreno, M. T. Organometallics 2004, 23, 3963-3975.

(15) Yamaguchi, T.; Yamazaki, F.; Ito, T. J. Am. Chem. Soc. 1999, 121, 7405-7406.

(16) Falvello, L. R.; Forniés, J.; Garde, R.; García, A.; Lalinde, E.; Moreno, M. T.; Steiner, A.; Tomás, M.; Usón, I. Inorg. Chem. 2006, 45, 2543-2552.

(17) Berenguer, J. R.; Díez, A.; Fernández, J.; Forniés, J.; García, A.; Gil, B.; Lalinde, E.; Moreno, M. T. Inorg. Chem. 2008, 47, 7703-7716.

(18) Falvello, L. R.; Forniés, J.; Martín, A.; Sicilia, V.; Villarroya, P. Organometallics 2002, 21, 4604-4610.

(19) Alonso, E.; Forniés, J.; Fortuño, C.; Martín, A.; Orpen, A. G. Organometallics 2003, 22, 5011-5019.

(20) Rochon, F. D.; Melanson, R. Acta Cryst. Sect. C: Cryst. Struct. Commun. 1988, 44, 474-477. 
(21) Forniés, J.; Fuertes, S.; Martín, A.; Sicilia, V.; Gil, B.; Lalinde, E. Dalton Trans. 2009, 2224-2234.

(22) Casas, J. M.; Forniés, J.; Fuertes, S.; Martín, A.; Sicilia, V. Organometallics 2007, 26, 1674-1685.

(23) Falvello, L. R.; Forniés, J.; Fortuño, C.; Durán, F.; Martín, A. Organometallics 2002, 21, 2226-2234.

(24) Ara, I.; Falvello, L. R.; Forniés, J.; Gómez, J.; Lalinde, E.; Merino, R. I.; Usón, I. J. Organomet. Chem. 2002, 663, 284-288.

(25) Falvello, L. R.; Forniés, J.; Lalinde, E.; Menjón, B.; García Monforte, M. A.; Moreno, M. T.; Tomás, M. Chem. Commun. 2007, 3838-3840.

(26) Yamaguchi, T.; Yamazaki, F.; Ito, T. J. Am. Chem. Soc. 2001, 123, 743-744.

(27) Forniés, J.; Ibáñez, S.; Lalinde, E.; Martín, A.; Moreno, M. T.; Tsipis, A. C. Dalton Trans. 2012, 41, 3439-3451.

(28) Fuertes, S.; Woodall, C. H.; Raithby, P. R.; Sicilia, V. Organometallics 2012, 31, 4228-4240.

(29) Belío, U.; Fuertes, S.; Martín, A. Inorg. Chem. 2013, 52, 5627-5629.

(30) Martín, A.; Belío, U.; Fuertes, S.; Sicilia, V. Eur. J. Inorg. Chem. 2013, 22312247.

(31) Chou, P. T.; Chi, Y. Chem. Eur. J. 2007, 13, 380-395.

(32) Cooke, M. W.; Hanan, G. S. Chem. Soc. Rev. 2007, 36, 1466-1476.

(33) Evans, R. C.; Douglas, P.; Wiscom, C. J. Coord. Chem. Rev. 2006, 250, 20932126.

(34) Holder, E.; Langeveld, B. M. W.; Schubert, U. S. Adv. Mater. 2005, 17, 11091121.

(35) McClenaghan, M. D.; Leydet, N. D.; Maubert, Y.; Indelli, M. T.; Campagna, S. Coord. Chem. Rev. 2005, 249, 1336-1350.

(36) Sun, S. S.; Lees, A. J. Coord. Chem. Rev. 2002, 230, 171-192.

(37) Wong, W. Y. Comments Inorg. Chem. 2005, 26, 39-74.

(38) Huynh, M. H. V.; Dattelbaum, D. M.; Meyer, T. J. Coord. Chem. Rev. 2005, 249, 457-483.

(39) Vogler, A.; Kunkely, H. Top. Curr. Chem. 2001, 213, 143-182.

(40) Thanasekaran, P.; Liao, R. T.; Liu, Y. H.; Rajendran, T.; Rajagopal, S.; Lu, K. L. Coord. Chem. Rev. 2005, 249, 1085-1110.

(41) Coord. Chem. Rev. 2000, 208 (special issue), 1-371. 
(42) Ma, B.; Djurovich, P. I.; Thompson, M. E. Coord. Chem. Rev. 2005, 249, 15011510 and references therein.

(43) Pérez, S.; López, C.; Caubet, A.; Bosque, R.; Solans, X.; Bardía, M. F.; Roig, A.; Molins, E. Organometallics 2004, 23, 224-236 and references therein.

(44) Fernández, E. J.; Laguna, A.; López de Luzuriaga, J. M. Dalton Trans. 2007, 1969.

(45) Modern Supramolecular Gold Chemistry; Antonio Laguna, Ed. Wiley-VCH, Weinheim, 2008.

(46) Crespo, O.; Laguna, A.; Fernández, E. J.; López de Luzuriaga, J. M.; Jones, P. G.; Teichert, M.; Monge, M.; Pyykkö, P.; Runeberg, N.; Schütz, M.; Werner, H. J. Inorg. Chem. 2000, 39, 4786-4792.

(47) Forniés, J.; Sicilia, V.; Casas, J. M.; Martín, A.; López, J. A.; Larraz, C.; Borja, P.; Ovejero, C. Dalton Trans. 2011, 40, 2898-2912.

(48) Martín, A.; Fuertes, S.; Belío, Ú. Dalton Trans. 2014, Accepted manuscript (DOI: 10.1039/C4DT00536H)

(49) Forniés, J.; Martín, A. In Metal Clusters in Chemistry; Braunstein, P., Oro, L. A., Raithby, P. R., Eds.; Wiley-VCH: Weinheim, 1999; Vol. 1, pp 417-443.

(50) Forniés, J.; Fortuño, C.; Ibáñez, S.; Martín, A. Inorg. Chem. 2008, 47, 5978-5987.

(51) Chen, W.; Liu, F.; Nishioka, T.; Matsumoto, K. Eur. J. Inorg. Chem. 2003, 42344243.

(52) Díez, A.; Forniés, J.; Gómez, J.; Lalinde, E.; Martín, A.; Moreno, M. T.; Sánchez, S. Dalton Trans. 2007, 3653-3660.

(53) Kampf, G.; Miguel, P. J. S.; Willermann, M.; Schneider, A.; Lippert, B. Chem. Eur. J. 2008, 14, 6882-6891.

(54) Janzen, D. E.; Mehne, L. F.; VanDerveer, D. G.; Grant, G. J. Inorg. Chem. 2005, $44,8182-8184$.

(55) Baudron, S. A.; Hosseini, M. W. Chem. Commun. 2008, 4558-4560.

(56) Yin, G.-Q.; Wei, Q.-H.; Zhang, L.-Y.; Chen, Z.-N. Organometallics 2006, 25, 580-587.

(57) Moret, M.-E.; Chen, P. Organometallics 2008, 27, 4903-4916.

(58) Berenguer, J. R.; Lalinde, E.; Moreno, M. T.; Sánchez, S.; Torroba, J. Inorg. Chem. 2012, 51, 11665-11679.

(59) Forniés, J.; Gómez, J.; Lalinde, E.; Moreno, M. T. Inorg. Chem. 2001, 40, 54155419. 
(60) Fuertes, S.; Brayshaw, S. K.; Raithby, P. R.; Schiffers, S.; Warren, M. R. Organometallics 2012, 31, 105-119.

(61) Braga, D.; Grepioni, F. Chem. Soc. Rev. 2000, 29, 229-238.

(62) Yuan, W.-B.; Yang, R.-D.; Tan, L. Trans. Met. Chem. 2004, 29, 380-381.

(63) Cotton, F. A.; Falvello, L. R.; Usón, R.; Forniés, J.; Tomás, M.; Casas, J. M.; Ara, I. Inorg. Chem. 1987, 26, 1366-1370.

(64) Usón, R.; Forniés, J.; Tomás, M.; Casas, J. M.; Cotton, F. A.; Falvello, L. R.; Llusar, R. Organometallics 1988, 7, 2279-2285.

(65) Usón, R.; Forniés, J.; Tomás, M.; Ara, I.; Casas, J. M.; Martín, A. J. Chem. Soc., Dalton Trans. 1991, 2253-2264.

(66) Usón, R.; Forniés, J.; Tomás, M.; Casas, J. M. Angew. Chem. Int. Ed. 1989, 28, 748-750.

(67) Forniés, J.; Navarro, R.; Tomás, M.; Urriolabeitia, E. P. Organometallics 1993, 12, 940-943.

(68) Casas, J. M.; Falvello, L. R.; Forniés, J.; Martín, A. Inorg. Chem. 1996, 35, 78677872.

(69) Usón, R.; Forniés, J.; Falvello, L. R.; Tomás, M.; Casas, J. M.; Martín, A. Inorg. Chem. 1993, 32, 5212-5215.

(70) Kuprat, M.; Lehmanm, M.; Schulz, A.; Villinger, A. Organometallics 2010, 29, 1421-1427.

(71) Son, J.-H.; Pudenz, M. A.; Hoefelmeyer, J. D. Dalton Trans. 2010, 39, 1108111090.

(72) Wade, C. R.; Yakovenko, A. A.; Gabbal, F. P. New J. Chem. 2010, 34, 16461651.

(73) Usón, R.; Forniés, J.; Menjón, B.; Cotton, F. A.; Falvello, L. R.; Tomás, M. Inorg. Chem. 1985, 24, 4651-4656.

(74) Forniés, J.; Martín, A.; Navarro, R.; Sicilia, V.; Villarroya, P.; G. Orpen, A. J. Chem. Soc., Dalton Trans. 1998, 3721-3726.

(75) Jamali, S.; Mazloomi, Z.; Nabavizadeh, S. M.; Milic, D.; Kia, R.; Rashidi, M. Inorg. Chem. 2010, 49, 2721-2726.

(76) Forniés, J.; Martínez, F.; Navarro, R.; Urriolabeitia, E. P. Organometallics 1996, 15, 1813-1819.

(77) Falvello, L. R.; Forniés, J.; Fortuño, C.; Gómez-Saso, M. A.; Menjón, B.; Rueda, Á. J.; Tomás, M. Inorg. Chim. Acta 1997, 264, 219-230. 
(78) Clarke, A. J.; Ingleson, M. J.; Kociok-Köhn, G.; Mahon, M. F.; Patmore, N. J.; Rourke, J. P.; Ruggiero, G. D.; Weller, A. S. J. Am. Chem. Soc. 2004, 126, 15031517.

(79) Chikkali, S. H.; Gudat, D.; Lissner, F.; Nieger, M.; Schleid, T. Dalton Trans. 2007, 3906-3913.

(80) Bachman, R. E.; Andretta, D. F. Inorg. Chem. 1998, 37, 5657-5663.

(81) Othman, A. H.; Yang, Y.-Y.; Chen, X.-M.; Ng, S. W. Acta Cryst. C 2000, 56, e318-e319.

(82) Tao, X.; Shen, K.-C.; Wang, Y.-L.; Shen, Y.-Z. Zeit. Anorg. Allg. Chem. 2011, 637, 1394-1400.

(83) Díez, A.; Forniés, J.; Larraz, C.; Lalinde, E.; López, J. A.; Martín, A.; Moreno, M. T.; Sicilia, V. Inorg. Chem. 2010, 49, 3239-3251.

(84) Forniés, J.; Sicilia, V.; Borja, P.; Casas, J. M.; Díez, A.; Lalinde, E.; Larraz, C.; Martín, A.; Moreno, M. T. Chem. Asian J. 2012, 7, 2813-2823.

(85) Yam, V. W.; Yu, K. L.; Cheung, K. K. J. Chem. Soc., Dalton Trans. 1999, 29132915.

(86) Charmant, J. P. H.; Forniés, J.; Gómez, J.; Lalinde, E.; Merino, R. I.; Moreno, M. T.; Orpen, A. G. Organometallics 1999, 18, 3353-3358.

(87) Gil, B.; Forniés, J.; Gómez, J.; Lalinde, E.; Martín, A.; Moreno, M. T. Inorg. Chem. 2006, 45, 7788-7798.

(88) Maslowsky, E. J. Vibrational Spectra of Organometallic Compounds; Wiley: New York, 1977.

(89) CysAlis RED, CCD camera data reduction program, Oxford Diffraction: Oxford, UK, 2004.

(90) Sheldrick, G. M. Acta Cryst. 2008, A64, 112-122.

(91) Spek, A. L. Acta Cryst. 2009, D65, 148-155.

(92) Frisch, M. J.; Trucks, G. W.; Schlegel, H. B.; Scuseria, G. E.; Robb, M. A.; Cheeseman, J. R.; Scalmani, G.; Barone, V.; Mennucci, B.; Petersson, G. A.; Nakatsuji, H.; Caricato, M.; Li, X.; Hratchian, H. P.; Izmaylov, A. F.; Bloino, J.; Zheng, G.; Sonnenberg, J. L.; Hada, M.; Ehara, M.; Toyota, K.; Fukuda, R.; Hasegawa, J.; Ishida, M.; Nakajima, T.; Honda, Y.; Kitao, O.; Nakai, H.; Vreven, T.; J. A. Montgomery, J.; Peralta, J. E.; Ogliaro, F.; Bearpark, M.; Heyd, J. J.; Brothers, E.; Kudin, K. N.; Staroverov, V. N.; Kobayashi, R.; Normand, J.; Raghavachari, K.; Rendell, A.; Burant, J. C.; Iyengar, S. S.; Tomasi, J.; Cossi, M.; 
Rega, N.; Millam, J. M.; Klene, M.; Knox, J. E.; Cross, J. B.; Bakken, V.; Adamo, C.; Jaramillo, J.; Gomperts, R.; Stratmann, R. E.; Yazyev, O.; Austin, A. J.; Cammi, R.; Pomelli, C.; Ochterski, J. W.; Martin, R. L.; Morokuma, K.; Zakrzewski, V. G.; Voth, G. A.; Salvador, P.; Dannenberg, J. J.; Dapprich, S.; Daniels, A. D.; Farkas, O.; Foresman, J. B.; Ortiz, J. V.; Cioslowski, J.; Fox, D. J.; Gaussian 09, Revision A.02, Gaussian, Inc.: Wallingford CT, 2009.

(93) Zhao, Y.; Truhlar, D. G. Theor. Chem. Acc. 2008, 120, 215-241.

(94) Andrae, D.; Haussermann, U.; Dolg, M.; Stoll, H.; Preuss, H. Theoretica Chimica Acta 1990, 77, 123-141.

(95) Ehlers, A. W.; Böhme, M.; Dapprich, S.; Gobbi, A.; Höllwarth, A.; Jonas, V.; Köhler, K. F.; Stegmann, R.; Veldkamp, A.; Frenking, G. Chem. Phys. Lett. 1993, 208, 111-114.

(96) Hehre, W. J.; Ditchfield, R.; Pople, J. A. J. Chem. Phys. 1972, 56, 2257-2261.

(97) Francl, M. M.; Pietro, W. J.; Hehre, W. J.; Binkley, J. S.; Gordon, M. S.; DeFrees, D. J.; Pople, J. A. J. Chem. Phys. 1982, 77, 3654-3665. 